\title{
Mediterranean sea turtles: current knowledge and priorities for conservation and research
}

\author{
Paolo Casale ${ }^{1, *}$, Annette C. Broderick ${ }^{2}$, Juan Antonio Camiñas ${ }^{3,4}$, Luis Cardona ${ }^{5}$, \\ Carlos Carreras ${ }^{6}$, Andreas Demetropoulos ${ }^{7}$, Wayne J. Fuller ${ }^{8}$, Brendan J. Godley ${ }^{2}$, \\ Sandra Hochscheid ${ }^{9}$, Yakup Kaska ${ }^{10}$, Bojan Lazar ${ }^{11,12}$, Dimitris Margaritoulis ${ }^{13}$, Aliki \\ Panagopoulou ${ }^{13,14}$, ALan F. Rees ${ }^{2,13}$, Jesús Tomás ${ }^{15}$, Oguz Türkozan ${ }^{16}$ \\ ${ }^{1}$ Department of Biology, University of Pisa, Via A. Volta 6, 56126 Pisa, Italy \\ Addresses for other authors are given in the Supplement at www.int-res.com/articles/suppl/n036p229_supp.pdf
}

\begin{abstract}
The available information regarding the 2 sea turtle species breeding in the Mediterranean (loggerhead turtle Caretta caretta and green turtle Chelonia mydas) is reviewed, including biometrics and morphology, identification of breeding and foraging areas, ecology and behaviour, abundance and trends, population structure and dynamics, anthropogenic threats and conservation measures. Although a large body of knowledge has been generated, research efforts have been inconsistently allocated across geographic areas, species and topics. Significant gaps still exist, ranging from the most fundamental aspects, such as the distribution of major nesting sites and the total number of clutches laid annually in the region, to more specific topics like age at maturity, survival rates and behavioural ecology, especially for certain areas (e.g. south-eastern Mediterranean). These gaps are particularly marked for the green turtle. The recent positive trends of nest counts at some nesting sites may be the result of the cessation of past exploitation and decades of conservation measures on land, both in the form of national regulations and of continued active protection of clutches. Therefore, the current status should be considered as dependent on such ongoing conservation efforts. Mitigation of incidental catch in fisheries, the main anthropogenic threat at sea, is still in its infancy. From the analysis of the present status a comprehensive list of research and conservation priorities is proposed.
\end{abstract}

KEY WORDS: Caretta caretta $\cdot$ Chelonia mydas $\cdot$ Nesting areas $\cdot$ Foraging grounds $\cdot$ Population abundance and trends $\cdot$ Population structure $\cdot$ Behavioural ecology $\cdot$ Biometrics

\section{INTRODUCTION}

The Mediterranean Sea hosts local populations of 2 sea turtle species, the loggerhead turtle Caretta caretta and the green turtle Chelonia mydas. These have been identified as 2 independent Regional Management Units (RMUs) (Wallace et al. 2010) out of 11 and 17 RMUs for the 2 species worldwide, respectively, and are the subject of the present review.

*Corresponding author: paolo.casale1@gmail.com
The Mediterranean is also frequented by turtles originating from Atlantic rookeries, including large numbers of loggerhead turtles (Encalada et al. 1998, Carreras et al. 2011, Clusa et al. 2014) and a limited number of leatherback turtles Dermochelys coriacea (Casale et al. 2003), and green, olive ridley Lepidochelys olivacea and Kemp's ridley turtles L. kempii (Tomás \& Raga 2008, Carreras et al. 2014, Revuelta et al. 2015).

(C) The authors 2018. Open Access under Creative Commons by Attribution Licence. Use, distribution and reproduction are unrestricted. Authors and original publication must be credited. 
An intense exploitation of sea turtles for food and international trade occurred in the Mediterranean in the 20th century until the 1970s, especially in the Levantine Basin with its dedicated fisheries (Hornell 1935, Sella 1982). The inclusion of loggerhead and green turtles, among other sea turtle species, in global initiatives such as CITES (Convention on International Trade in Endangered Species of Wild Fauna and Flora) in 1981 and the Red List of the IUCN (International Union for Conservation of Nature) in 1982 solicited and promoted legal protection at national level in Mediterranean countries, interrupting legal trade both at international and domestic levels. Several NGOs started to work on sea turtle conservation in the 1980s, although monitoring and conservation activities at nesting sites had already started in the late 1970s in some cases (Casale \& Margaritoulis 2010).

The conservation challenges deriving from the geopolitical complexity of the region, and the poor knowledge of some fundamental aspects of biology has stimulated periodic reviews, which have been conservation-oriented, about one or both sea turtle species breeding in the region (Groombridge 1990, Margaritoulis et al. 2003, Casale \& Margaritoulis 2010). Studies on sea turtles in the Mediterranean started in association with conservation projects, focusing mainly on nesting site monitoring and protection, and scientific publications clearly increased during the 1990s and have further increased since 2010 (Fig. 1).

Given the proliferation of publications in recent years, this review aims to (1) collate and summarise

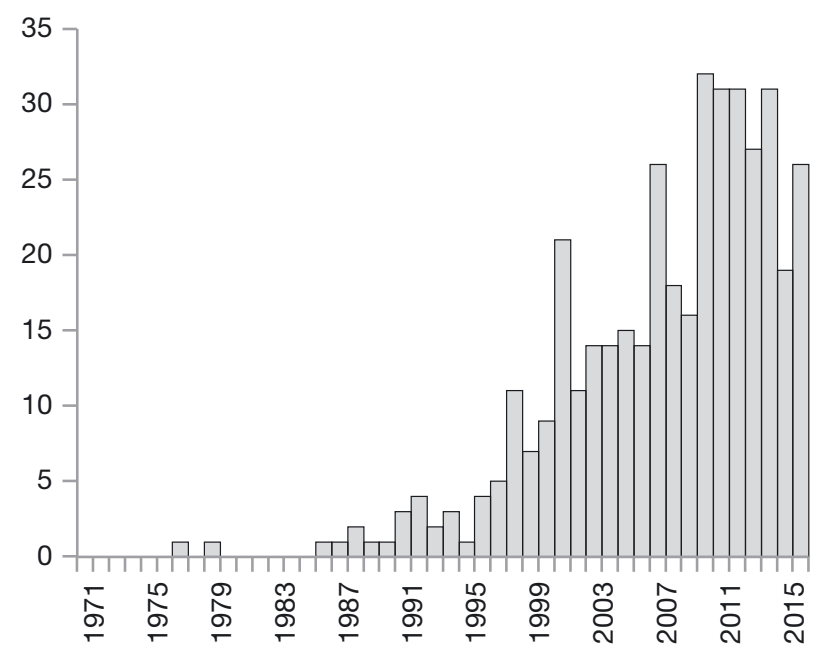

Fig. 1. Annual number of scientific publications on sea turtles in the Mediterranean Sea in the period 1971-2016 indexed by Scopus $(\mathrm{n}=403)$ the current knowledge of the key aspects of biology and conservation of the 2 sea turtle species breeding in the Mediterranean, (2) highlight the main knowledge gaps and recommend priorities for research and conservation, and (3) provide a framework for facilitating the updating of a comprehensive knowledge base into the future.

\section{BIOMETRICS AND MORPHOLOGY}

One of the most distinctive characteristics of Mediterranean loggerhead turtles is a smaller adult female size in comparison to other populations worldwide (Dodd 1988, Tiwari \& Bjorndal 2000, Kamezaki 2003). This is not the case for Mediterranean green turtles, although they are in the lower part of the range for the species globally (Seminoff et al. 2015). Within the Mediterranean, adult body size varies among different nesting sites for both species (see Tables S1 \& S2 in the Supplement).

It is not clear if size differs according to sex. Limited data suggest that adult male green turtles are, on average, smaller than females (Godley et al. 2002a). Adult loggerhead males have been found to be larger than females at a foraging area (Amvrakikos Gulf) (Rees et al. 2013), although a spatial effect cannot be excluded given that less than $5 \%$ of that area was sampled, and during the period when a proportion of females were nesting in areas outside the bay. No sexually dimorphic size differences were reported at one of the largest breeding aggregations in the Mediterranean (Zakynthos, Greece) (Schofield et al. 2013a, 2017a) (see Table S1). Tail length, the main sea turtle sexual dimorphism, starts to increase in loggerhead males larger than $60 \mathrm{~cm}$ curved carapace length (CCL) and a clear dichotomy in this trait is evident in the population in the $>75 \mathrm{~cm}$ CCL size class (Casale et al. 2005, 2014).

Since body proportions may vary among populations, equations to convert between CCL, straight carapace length (SCL), curved carapace width (CCW) (Bolten 1999) and weight are needed for comparative studies and for identifying body condition in turtles under rehabilitation. For Mediterranean loggerheads these equations are available in Casale et al. (2017).

Egg and hatchling size data are provided in the Supplement in Tables S3 \& S4 for loggerhead turtles and Tables S5 \& S6 for green turtles. Egg and hatchling size of loggerheads are significantly positively correlated (Özdemir et al. 2007), with no similar data published for green turtles. 
Variation in patterns of carapacial scutes has been investigated at several nesting and in-water areas (see Tables S7 \& S8 in the Supplement). The marginal scute pattern for loggerhead turtles is the most variable and displays some notable spatial variation within the Mediterranean. The most prevalent pattern is 12 pairs of scutes, with hatchling turtles from Greece more commonly presenting 11 pairs. For those turtles with an asymmetric number of scutes, the left side is statistically more likely to present the higher number (Margaritoulis \& Chiras 2011, Casale et al. 2017). Less variation is found in adult loggerhead turtles than in hatchlings (see Table S7). Few data are available on loggerhead plastron and head scute patterns (Schofield et al. 2008, Margaritoulis \& Chiras 2011, Oliver 2014, Casale et al. 2017). A study of geometric morphometrics of loggerheads revealed moderate but significant allometric growth in head, flippers and carapace, but indicated that the more extensive non-allometric changes, possibly based on sex or population origin, were more significant and worthy of investigation (Casale et al. 2017).

In conclusion, although size is commonly measured during field work, there are still important gaps in the availability of size data, especially regarding green turtles. Such data may help elucidate aspects of sea turtle biology, such as sexual dimorphism or recruitment at nesting sites and adult growth rates. Morphological variation may signal differences (natural and anthropogenic) in the developmental environment. In this respect, the observed difference between hatchlings and adults is intriguing.

\section{NESTING AREAS}

The distribution of sea turtle nesting in the Mediterranean has been assessed several times (e.g. Groombridge 1990, Kasparek et al. 2001, Margaritoulis et al. 2003, Casale \& Margaritoulis 2010, Casale \& Mariani 2014, Stokes et al. 2015, Almpanidou et al. 2016). Given that sea turtles, and especially loggerheads, may potentially lay clutches throughout the Mediterranean, ranging from high density to scattered nesting activity, defining nesting sites according to their relative importance is useful. Neither abundance nor density alone can capture the real importance of a nesting site. For instance, there are cases where high numbers of clutches are spread along extensive coastal tracts with low density or where there are sites with low clutch numbers at high densities over very short distances. Therefore, we defined as major nesting sites those with values above arbitrary thresholds for both clutch numbers $\left(>10 \mathrm{yr}^{-1}\right.$ ) and clutch density $\left(>3 \mathrm{~km}^{-1} \mathrm{yr}^{-1}\right)$. This resulted in 52 and 13 major nesting sites for loggerhead and green turtles, respectively (see Tables S9 \& S11 in the Supplement).

No nesting activity of either species has been documented for Algeria, Morocco, Monaco or the eastern Adriatic (Albania, Bosnia and Herzegovina, Croatia, Montenegro, Slovenia). The other countries host nesting sites ranging from a few scattered nests to large and dense aggregations of 1 or both species (Figs. $2 \& 3$ ). The occurrence of sea turtle nesting activity has been assessed in most countries, and some nesting sites in Cyprus, Greece and Turkey

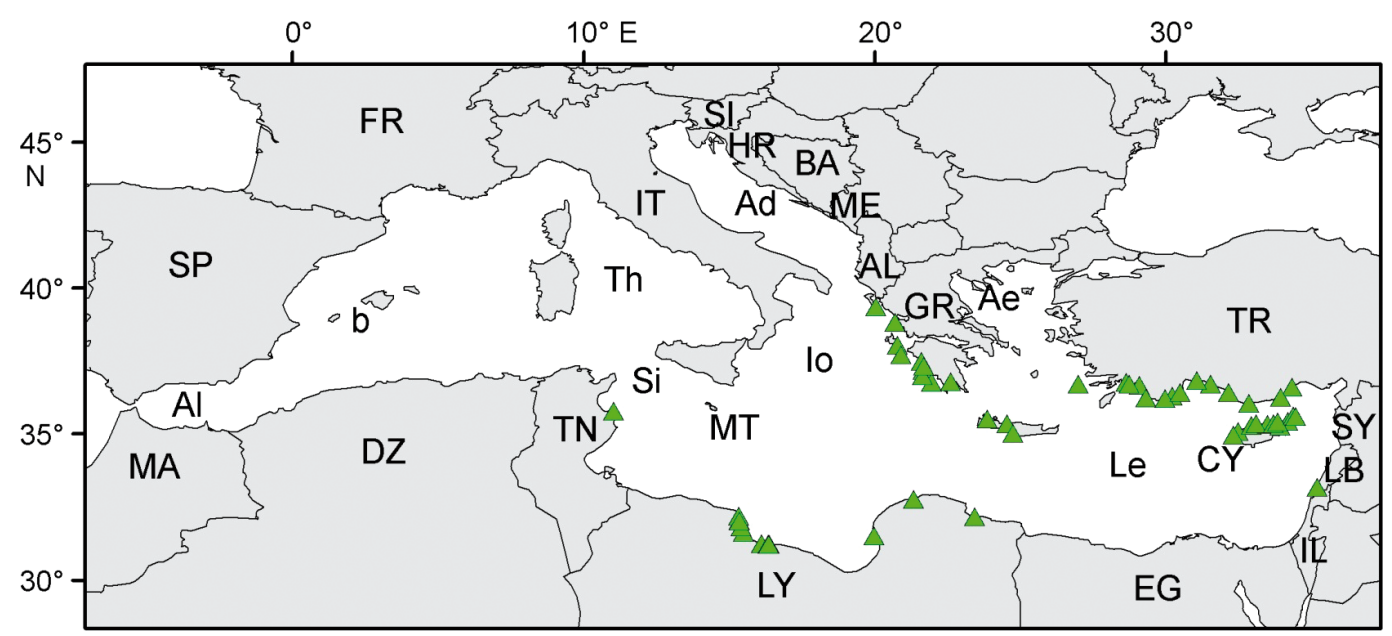

Fig. 2. Major nesting sites (i.e. $\geq 10$ clutches $\mathrm{yr}^{-1}$ and $\geq 2.5$ clutches $\mathrm{km}^{-1}$ ) of loggerhead turtles Caretta caretta in the Mediterranean. Countries: AL: Albania; DZ: Algeria; BA: Bosnia and Herzegovina; HR: Croatia; CY: Cyprus; EG: Egypt; FR: France; GR: Greece; IL: Israel; IT: Italy; LB: Lebanon; LY: Libya; MT: Malta; ME: Montenegro; MA: Morocco; SI: Slovenia; SP: Spain; SY: Syria; TN: Tunisia; TR: Turkey. Marine areas: Ad: Adriatic Sea; Ae: Aegean Sea; Al: Alboran Sea; Io: Ionian Sea; Le: Levantine Basin; Si: Sicilian Strait; Th: Tyrrhenian Sea; b: Balearic Islands (Spain) 

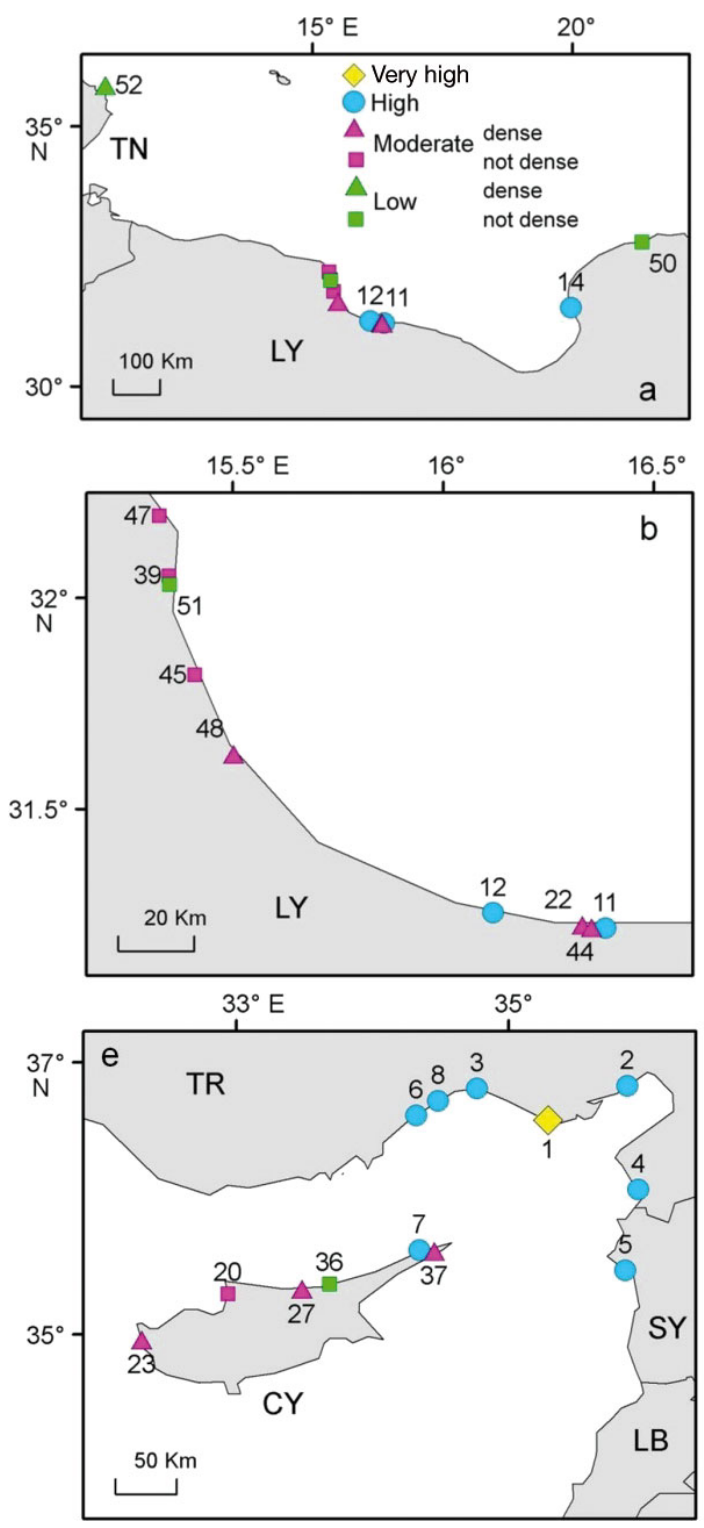

have been monitored since the 1970s or 1980s (see Section 8.2), However, there are still significant gaps. For instance, the occurrence of nesting activity along most of the sandy coast of Libya has never been investigated (Hamza 2010).

With the exceptions mentioned above, although loggerhead turtle nesting occurs across the Mediterranean Basin, more than $96 \%$ of clutches are laid in Greece, Turkey, Libya and Cyprus (Figs. 2 \& 3, see Table S9). Lower levels of nesting take place along the Mediterranean coasts of Egypt, Israel, Italy, Lebanon, Syria and Tunisia, with minor and infrequent nesting occurring along the western basin coastlines of Spain, France, Italy and their

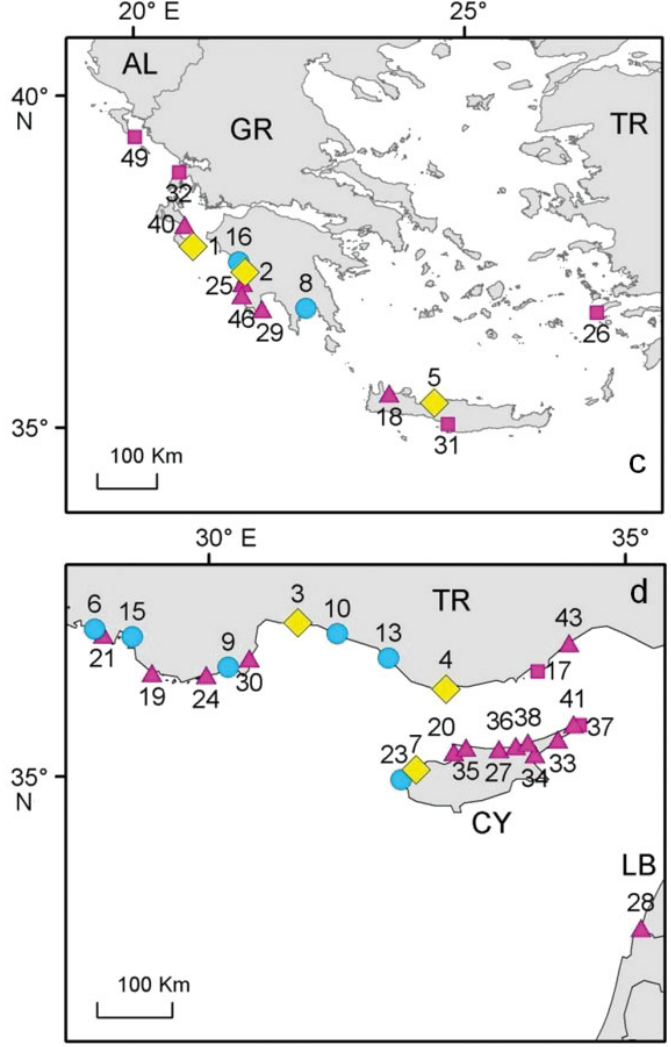

Fig. 3. Major nesting sites ( $\geq 10$ clutches $\mathrm{yr}^{-1}$ and $\geq 2.5$ clutches $\mathrm{km}^{-1} \mathrm{yr}^{-1}$ ) of loggerhead turtles Caretta caretta in (a) Tunisia and Libya; (b) Libya showing the close nesting sites from the central part of (a); (c) Greece; (d) Turkey, Cyprus and Lebanon; and (e) of green turtles Chelonia mydas. Numbers link to nesting sites listed in Tables S9 \& S11 in the Supplement for loggerhead and green turtles, respectively. Symbols represent classes of nesting activity: Very high (>300 clutches $\left.\mathrm{yr}^{-1}\right)$, High (100-300 clutches $\left.\mathrm{yr}^{-1}\right)$, Moderate-dense (20-99 clutches $\mathrm{yr}^{-1} ; \geq 6.5$ clutches $\mathrm{km}^{-1} \mathrm{yr}^{-1}$ ), Moderate-not dense (20-99 clutches $\mathrm{yr}^{-1} ; 2.5-6.5$ clutches $\mathrm{km}^{-1} \mathrm{yr}^{-1}$ ), Lowdense (10-19 clutches $\mathrm{yr}^{-1} ; \geq 6.5$ clutches $\left.\mathrm{km}^{-1} \mathrm{yr}^{-1}\right)$, Low-not dense (10-19 clutches $\mathrm{yr}^{-1} ; 2.5-6.5$ clutches $\mathrm{km}^{-1} \mathrm{yr}^{-1}$ ). Country codes as in Fig. 2

offshore islands (see Tables S9 \& S10 in the Supplement). The nesting sites with the highest number of clutches per year for loggerhead turtles are Zakynthos Island (with also the highest nest density), Kyparissia Bay (both in Greece), Belek, Anamur (Turkey) and Chrysochou Bay (Cyprus) (see Tables S9 \& S10).

The 13 major green turtle rookeries are located in Turkey, Cyprus and Syria, with minor nesting aggregations occurring in Egypt, Lebanon and Israel (Fig. 3, see Tables S10 \& S11). An exceptional green turtle nesting site was recorded in Rethymno, Crete (Greece) in 2007 (Margaritoulis \& Panagopoulou 2010), representing the westernmost nesting record 
in the Mediterranean. The largest nesting rookery for green turtles is Akyatan beach (Turkey), hosting about $20 \%$ of the total number of clutches recorded in the Mediterranean.

In conclusion, although the distribution of nesting sites in the Mediterranean is assumed to be relatively well known, the lack of any information on the extensive coast of Libya represents a major knowledge gap. Moreover, given that nesting sites may have very high nest densities and occur along very short coastal tracts, the existence of other major and/or minor nesting sites around the Mediterranean cannot be excluded. In this respect, it is interesting to note that a major nesting site for green turtles has been discovered only in relatively recent years (Rees et al. 2008).

\section{MARINE AREAS, ECOLOGY AND BEHAVIOUR}

\subsection{Nursery areas}

Oceanic (i.e. off the continental shelf, conventionally defined by the $200 \mathrm{~m}$ isobath) nursery areas for post-hatchling and small juvenile loggerhead turtles $(<40 \mathrm{~cm}$ CCL) are largely unknown in the Mediterranean. Eckert et al. (2008) tracked 4 small loggerhead turtles ( 26 to $32 \mathrm{~cm}$ CCL) from the Alboran Sea, two of which moved eastward, arriving at the Sardinia Channel and Ionian Sea, respectively. With the exception of this study, knowledge of post-hatchling dispersal and high-density areas for small oceanic juveniles essentially relies on numerical simulations of particle distribution (Hays et al. 2010a, Casale \& Mariani 2014, Maffucci et al. 2016, Cardona \& Hays 2018). These suggest that the Levantine Basin is a nursery area for turtles originating from eastern rookeries, whereas turtles hatching in Greece and the central Mediterranean nesting areas disperse mainly in the Ionian, south-central Mediterranean and Adriatic Seas (Casale \& Mariani 2014). These dispersal patterns are supported by high incidences of small $(<30 \mathrm{~cm})$ turtle strandings along the Ionian and Adriatic coasts of Italy (Casale et al. 2010a) and the southern coast of Turkey (Türkozan et al. 2013). On the basis of these simulations, dispersal into the western Mediterranean is unlikely to occur during the first 6 mo of life (see following sections for older ages). Limited exchange between the 2 basins has been estimated for hatchlings and post-hatchlings originating in the western Mediterranean. These are mostly retained in the South Tyrrhenian Sea, with dispersion to the north-western part (Maffucci et al.
2016). Notably, it appears that the western Mediterranean is unsuitable as a nursery area under current climatic conditions, as post-hatchlings are unlikely to survive the colder winter temperatures in this basin (Maffucci et al. 2016).

Knowledge of green turtle post-hatchling dispersal and high-density areas for small oceanic juveniles relies on numerical simulations of particle distribution (Putman \& Naro-Maciel 2013, Casale \& Mariani 2014), which suggest that the Levantine Basin is the main nursery area for this species. This is supported by high incidences of small $(<30 \mathrm{~cm}$ CCL) turtle strandings on the southern coast of Turkey (Türkozan et al. 2013). Green turtles of $<30 \mathrm{~cm}$ CCL have also been reported in Fethiye Bay, western Turkey (Türkozan \& Durmus 2000) and the north of Cyprus (Snape et al. 2013).

\subsection{Oceanic foraging areas}

Loggerhead turtles, especially juveniles, can be found in virtually all oceanic areas within the Mediterranean. Their distribution is fundamentally driven by the circulation system of the Mediterranean, as indicated by studies based on genetics (Carreras et al. 2006, Clusa et al. 2014, Cardona \& Hays 2018), telemetry (Carreras et al. 2006, Revelles et al. 2007C, Zbinden et al. 2008, Schofield et al. 2010a, Cardona \& Hays 2018) and flipper tagging (Casale et al. 2007a, Revelles et al. 2008).

Identifying the most frequented areas is not a simple task, and the most promising approach is represented by estimating turtle density at the surface through aerial surveys, on the condition that different surveys are similar in technical aspects such as altitude (affecting detection of turtles of a certain size) and that data are corrected for perception bias. Unfortunately, aerial survey data are available for only 2 areas of the western Mediterranean, with higher densities of turtles at the sea surface reported in the southwestern area (Spain) (Gómez de Segura et al. 2006) than in the north-eastern area (ItalyFrance) (Lauriano et al. 2011). Although several biological (e.g. proportion of time spent at surface, interannual variability) and technical parameters (e.g. different altitude) may have affected the estimated turtle surface density, the order of magnitude of the observed difference and other indices such as bycatch rates (see following paragraph) suggest a real difference in abundance between the 2 areas.

Without the availability of extensive aerial surveys, at present the best insights into at-sea turtle distribu- 
tion are provided by interaction with fisheries. However, captures are affected by several technical and operational factors which can vary greatly among fisheries and can thus represent sources of biases. While in oceanic zones, loggerhead turtles feed upon pelagic prey and are attracted by fishing baits such as fish or squid on hooks of pelagic longlines set near the surface. Therefore, turtle catch rates (catch per unit of effort or CPUE) by this fishing gear can provide a rough indication of the relative abundance in different areas. The highest CPUE values for pelagic longlines in the Mediterranean (approximately 1 turtle for each 1000 hooks) have been observed in the westernmost part of the Mediterranean (Morocco, southern Spain and the Balearic Islands), the southern Ionian/Sicilian Strait and the northern Ionian/ South Adriatic, while CPUE is 10 times lower in the Tyrrhenian Sea and the northern part of the western basin (Casale 2011). In the Tyrrhenian Sea, juveniles and adult-sized turtles foraging on pelagic prey frequent the oceanic waters around the Aeolian Archipelago, north of Sicily (Blasi \& Mattei 2017). Moreover, a recent satellite-tracking study has revealed a high use area in the southern Tyrrhenian Sea (Luschi et al. 2018), so this basin may be of importance for loggerhead turtles foraging in the oceanic realm. Other areas where satellite-tracked turtles have taken up residence, presumably for foraging, are the Algerian Sea (Hays et al. 2014a), the deep waters of the Sicilian Strait (Bentivegna 2002, Casale et al. 2012c), the western Ionian (Mingozzi et al. 2016) and the central Ionian (Zbinden et al. 2008, Schofield et al. 2010a). Unfortunately, similar data are not yet available from all areas, and are lacking in particular for the Levantine Basin.

Loggerhead turtles in oceanic zones belong to at least 3 different RMUs (Wallace et al. 2010): the Mediterranean, the northwest Atlantic and, to a lesser extent, the northeast Atlantic (Clusa et al. 2014). Juveniles from Atlantic RMUs enter the Mediterranean through the Strait of Gibraltar and mainly disperse across the south of the western basin with the less saline waters from the Atlantic (Millot 2005). They are also found in other regions of the Mediterranean, but they represent less than $20 \%$ of individuals except in the Alboran Sea and the Algerian Basin (Revelles et al. 2007b, Clusa et al. 2014). Juveniles from the Mediterranean RMU can be found throughout the basin, although their relative proportion is higher than $80 \%$ in the eastern, central and north-western Mediterranean and less than $45 \%$ in the Alboran Sea and the Algerian Basin (Clusa et al. 2014).
The juvenile life-history stage of green turtles is poorly known in the Mediterranean. Presumably, the highest juvenile green turtle concentration is in the eastern basin, particularly in the Levantine where post-hatchlings are distributed (see Section 4.1). However, the presence of small juvenile green turtles $(\leq 40 \mathrm{~cm}$ CCL) in Lakonikos Bay, Greece (Margaritoulis \& Panagopoulou 2010) and in the southern Adriatic Sea (Lazar et al. 2004a), as well as of juvenile green turtles $<50 \mathrm{~cm}$ CCL in Patok Bay in Albania (Haxhiu 2010), suggests that juvenile green turtles may use oceanic habitats between their natal sites and the Adriatic. Genetic markers indicate that the few individuals occurring in the western basin come from the Atlantic (Carreras et al. 2014).

\subsection{Neritic foraging and wintering areas}

In contrast to oceanic foraging grounds, the neritic (i.e. over the continental shelf) foraging grounds are usually more frequented by larger turtles, including adults. A synthesis of the available information is shown in Fig. 4. As in oceanic areas, a rough indication of the relative abundance in different neritic areas can be provided by the rate of turtles incidentally caught by fisheries and especially by bottom trawlers.

The highest catch rates of loggerhead turtles in the Mediterranean have been observed off Tunisia, in the Adriatic Sea and in the easternmost part of the Levantine Basin, off Turkey, Syria and Egypt (Casale 2011, Casale et al. 2012e) (Fig. 4). Flipper tagging (Margaritoulis 1988b, Margaritoulis et al. 2003, Casale et al. 2007a, Margaritoulis \& Panagopoulou 2010), satellite tracking (Zbinden et al. 2011, Schofield et al. 2013a, Luschi \& Casale 2014, Patel et al. 2015a,b, Snape et al. 2016, Rees et al. 2017) and strandings (Casale et al. 2010a, Türkozan et al. 2013) also support the relative importance of these neritic areas as well as of other areas such as the Aegean Sea, northern Africa, the eastern Mediterranean coast of Turkey and western Greece (Fig. 4). Loggerhead turtles are also known to frequent some neritic areas in the western Mediterranean, such as the Spanish continental shelf (Bertolero 2003, Cardona et al. 2009 and references therein, Álvarez de Quevedo et al. 2010, Domènech et al. 2015), the Balearic Islands (Carreras et al. 2004) and the southwestern coasts of Italy (Hochscheid et al. 2007) (Fig. 4), although probably at lower levels of abundance.

With few exceptions, the presence of loggerhead turtles in neritic foraging habitats largely overlaps 


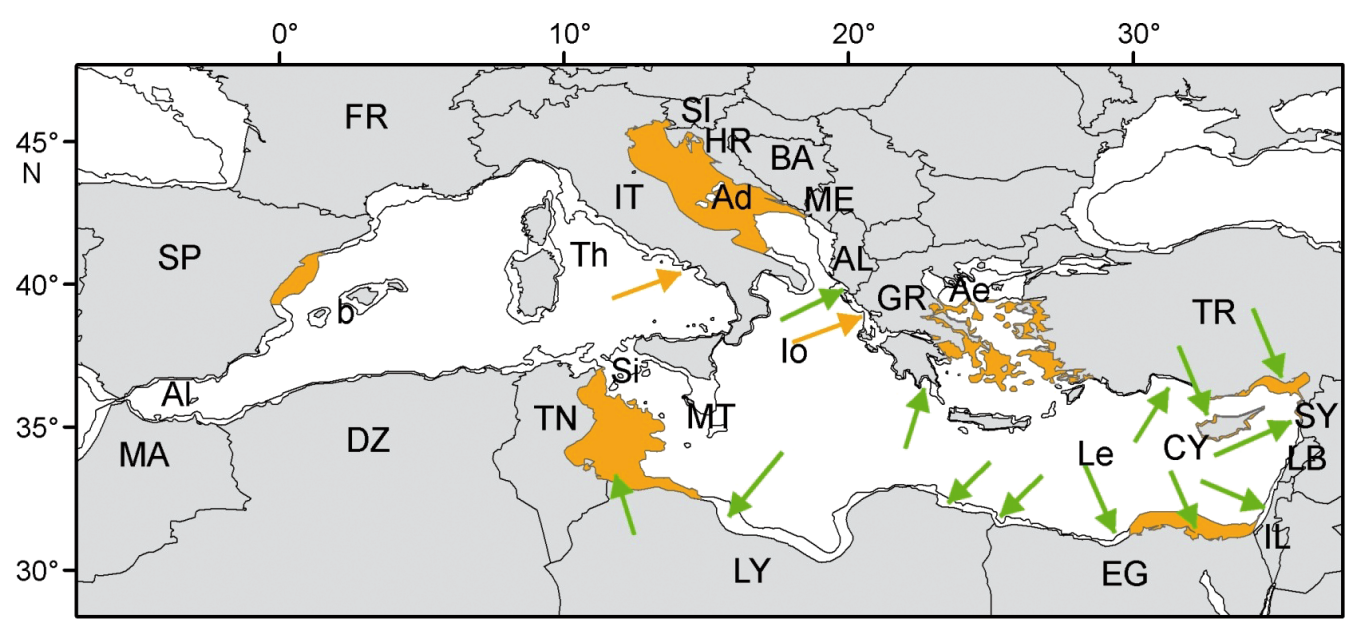

Fig. 4. Neritic foraging and wintering sites for loggerhead turtles Caretta caretta (orange areas and arrows) and green turtles Chelonia mydas (green arrows). Neritic areas correspond to the continental shelves, which are conventionally delimited by the $200 \mathrm{~m}$ isobath (solid line). See Section 4.3 for detailed description and sources. Country and sea codes as in Fig. 2

with the distribution of foraging habitats modelled by Mazor et al. (2016). Generally, loggerhead turtles tend to overwinter within or in the vicinity of their foraging areas, although some turtles may move from cold areas like the Adriatic during the winter (Zbinden et al. 2008, Schofield et al. 2013a) (see also Section 4.7).

Information on the neritic foraging areas of green turtles is relatively scarce and is summarised in Fig. 4. Insights about areas frequented by juveniles are mostly provided by stranding reports and fishery bycatch, although it is difficult to extract relative abundances. Foraging areas are known to occur along the coast of Turkey (Çukurova region, Samandağ, Fethiye and Iskenderun Bay) (Türkozan \& Kaska 2010), Cyprus (Demetropoulos \& Hadjichristophorou 2010, Fuller et al. 2010, Snape et al. 2013), Syria (especially shallow waters north of Latakia, with a higher abundance of juveniles in winter) (Rees et al. 2010), Israel (Levy 2010), Egypt (Nada \& Casale 2010), Libya (Ain al Ghazalah lagoon and Gulf of Sirte) (Hamza 2010), Greece (Lakonikos Bay, southern Peloponnese) (Margaritoulis \& Panagopoulou 2010) and Albania (Haxhiu 2010) (Fig. 4).

Additional information has been provided through satellite tracking of adults from nesting sites. Stokes et al. (2015) summarised all the results from 34 tracks of adult green turtles released from nesting beaches in Cyprus $(n=22)$, Turkey $(n=8)$, Syria $(n=1)$ and Israel $(n=3)$. These turtles travelled to, and stayed in, foraging areas along the coast of -in descending order of importance - Libya (Gulf of Sirte and Gulf of Bomba) and Turkey (mainly Gulf of Antalya) and to less frequented, disparate sites off Lebanon, Egypt and the Tunisian-Libyan border (Fig. 4). A later study including stable isotopes and additional tracking highlighted the major importance of Lake Bardawil in Egypt, especially recently (Bradshaw et al. 2017). Stranding data reports indicate the presence of adult green turtles in the Aegean Sea, especially around Rhodes (Margaritoulis \& Panagopoulou 2010), as well as along the coast of Israel (Levy 2010, Levy et al. 2017). Wintering areas of green turtles are generally the same areas as their foraging sites, with a high fidelity generally shown to both (Broderick et al. 2007, Stokes et al. 2014).

\subsection{Migratory corridors}

Migratory corridors, i.e. passages across habitats that are frequently used by migrating animals, have been identified exclusively using satellite telemetry (Figs. 5 \& 6). Information on migratory corridors of loggerhead turtles is mainly represented by breeding migrations of adults and particularly post-breeding migrations from the breeding area to foraging grounds (Schofield et al. 2013a,b, Dujon et al. 2014, Luschi \& Casale 2014, Patel et al. 2015a, Mingozzi et al. 2016, Snape et al. 2016). These corridors are thus used at the end of the breeding season, predominantly in July and August for females and in May and June for males. Adults have also been tracked during prebreeding migrations, although at lower numbers due to the logistical challenges of tracking a turtle from breeding or foraging grounds until their next breeding season (Zbinden et al. 2008, Hays et al. 2010b, Schofield et al. 2010a, Casale et al. 2013a, Mingozzi et al. 2016, Snape et al. 2016). The consistency of routes is variable (Broderick et al. 2007, Schofield et 


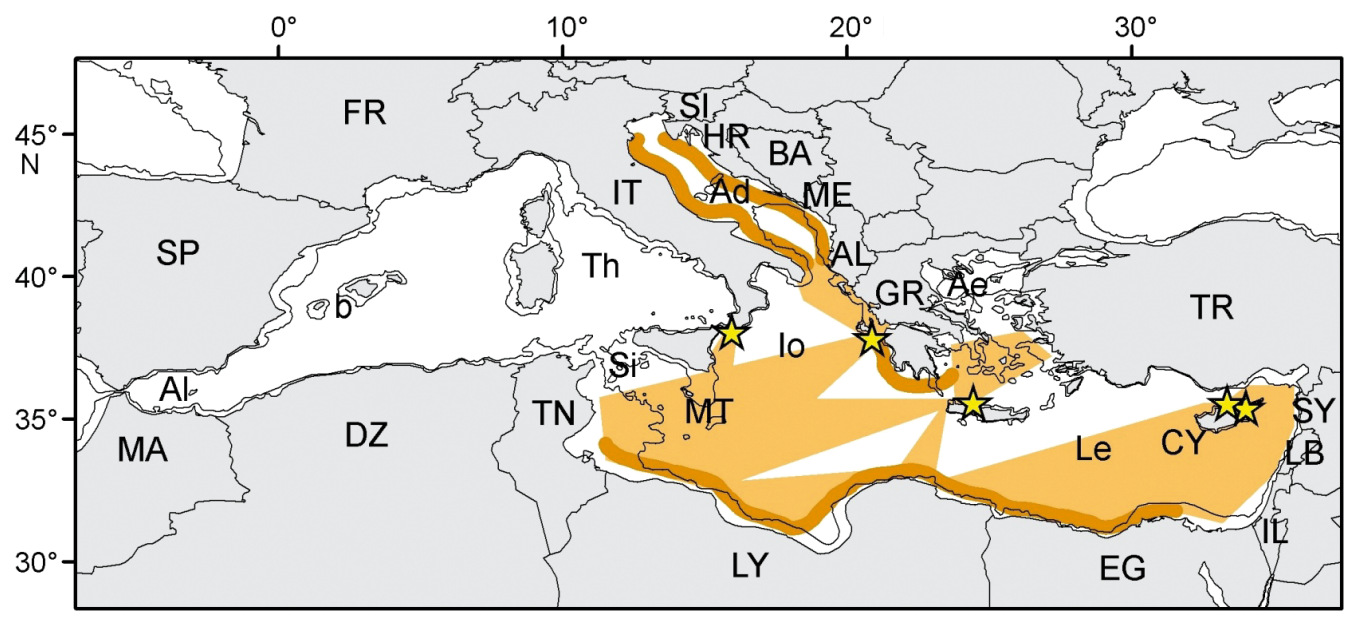

Fig. 5. Main known migratory corridors for adult loggerhead turtles Caretta caretta (females and males) during reproductive migrations from and to the breeding sites ( 5 ). Light brown areas represent migratory funnels in the open sea while darker strips represent paths along the coasts, typically in shallow waters. See Section 4.4 for details and sources. Country and sea codes as in Fig. 2

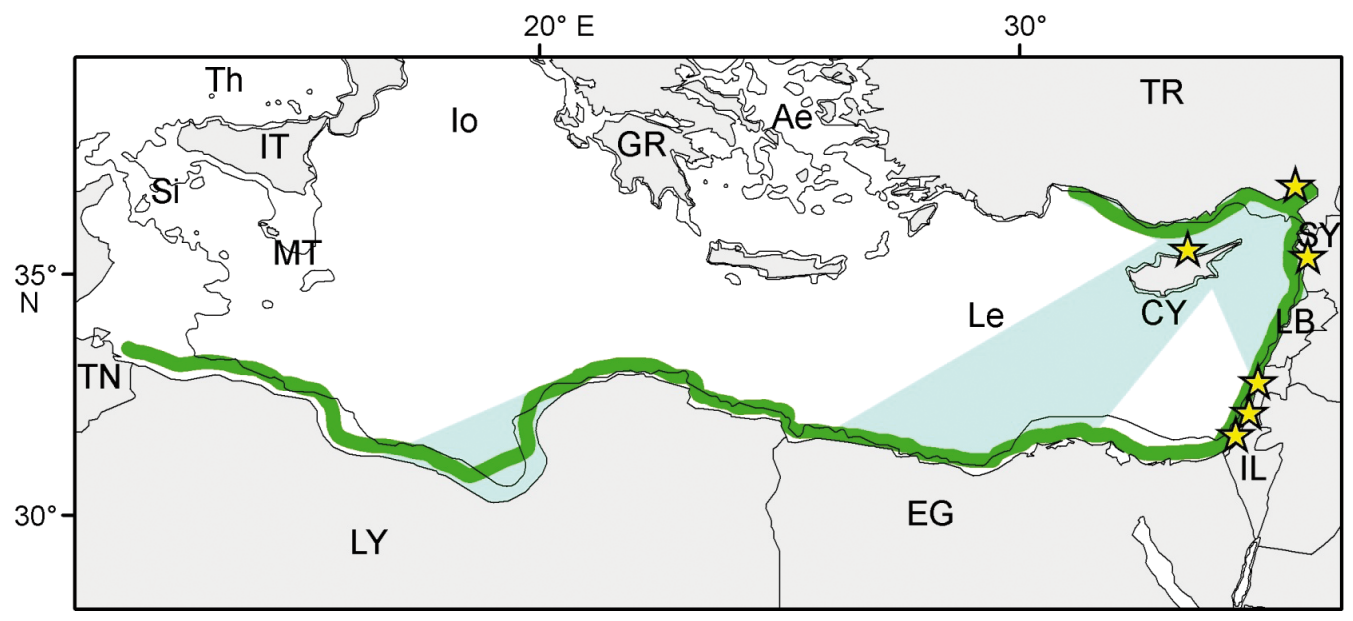

Fig. 6. Main known migratory corridors for adult female green turtles Chelonia mydas during reproductive migrations from the breeding sites $(\hat{\xi})$. Light green areas represent migratory funnels in the open sea while darker strips represent paths along the coasts, typically in shallow waters. Adapted from Stokes et al. (2015). Country and sea codes as in Fig. 2

al. 2010a) and is generally much lower when turtles traverse large open areas (Hays et al. 2014a), making migratory corridors rather broad (Fig. 5).

In addition, considerable inter-basin exchange is funnelled through narrow physical passages, such as the Strait of Messina, Strait of Otranto and Sicilian Strait. Some of these movements may be correlated to seasonal migrations that are thought to occur in the northernmost and colder regions of the western Mediterranean (see Section 4.7) (Bentivegna 2002, Hochscheid et al. 2005, Zbinden et al. 2011, Casale et al. 2012a, Luschi et al. 2013). They may also be correlated to post-nesting migrations, especially for loggerhead turtles nesting in Greece moving to Adriatic foraging grounds in late summer (Zbinden et al. 2011, Schofield et al. 2013a).
Regarding green turtles, published tracking data have been summarised by Stokes et al. (2015) for adults tracked during their post-breeding migrations, mostly from Cyprus and Turkey and a few from Israel and Syria. The identified migratory corridors are located between Turkey and Egypt and along the northern African coast (Fig. 6).

\subsection{Geographical connectivity and habitats: dispersal, settlement and migration}

Genetic markers have revealed a differential distribution at foraging grounds of larger juvenile loggerhead turtles (23 to $69 \mathrm{~cm} \mathrm{CCL}$ ) originating from different populations (Carreras et al. 2006, 2011, 
Maffucci et al. 2006, Garofalo et al. 2013, Clusa et al. 2014, Karaa et al. 2016, Turkozan et al. 2018), which is consistent with the patterns suggested by virtual particle modelling (see Section 4.1) and by breeding migrations (see Section 4.4). Water circulation in the Mediterranean is driven by a negative water balance, leading to the massive inflow of surface water from the Atlantic across the Strait of Gibraltar which causes a cyclonic flow of surface water $(<200 \mathrm{~m}$ deep) across the whole basin (Millot 2005). An integration of empirical and modelling results (Casale \& Mariani 2014) proposed 4 main dispersal areas/ aggregations: the Levantine zone, which is frequented mainly by turtles originating from the same region (Turkey, Cyprus, eastern Greece), the southcentral Mediterranean, frequented by turtles originating from the same region (Libya), the Adriatic, frequented by turtles from rookeries in western Greece, and the Ionian, which seems to be frequented by turtles originating from all the above regions. Likewise, satellite tracking in the western Mediterranean has confirmed that oceanic juveniles of 37 to $63 \mathrm{~cm}$ SCL remain within specific water masses (Revelles et al. 2007a, 2008). Such association between large oceanic juvenile loggerhead turtles and water masses is intriguing, as laboratory experiments (Revelles et al. 2007b) and satellite tracking (Bentivegna et al. 2007) have demonstrated that turtles larger than $40 \mathrm{~cm}$ may swim independently of currents. This apparent contradiction is coherent with the Learned Migration Goal Theory that postulates that adult and subadult individuals tend to use the same foraging areas that they used as juveniles (Hays et al. 2010a, Scott et al. 2014). In this context, modelling suggests that juvenile loggerhead turtles smaller than $65 \mathrm{~cm}$ CCL have a limited capacity to detect or respond to environmental variations (Eckert et al. 2008) and that the atsea distribution of oceanic loggerhead turtles ranging from 40 to $69 \mathrm{~cm}$ CCL is largely consistent with passive drift within a basin broadly favourable for developing loggerhead turtles (Cardona \& Hays 2018).

Loggerhead turtles in the Mediterranean Sea start to inhabit neritic habitats from $25 \mathrm{~cm}$ CCL (Casale et al. 2008a), which is in sharp contrast to the situation in the Atlantic and the Pacific Oceans. Casale et al. (2008a) proposed a general life-history model where an early, short obligate epipelagic stage due to limited diving capacity is followed by a stage during which the turtles gradually shift to feeding upon benthic prey as they grow and improve their benthic foraging efficiency. While in ocean basins this pattern results in a delayed and rapid habitat shift; in the
Mediterranean, this high degree of plasticity and the limited geographical dispersal of young loggerhead turtles within a small basin results in an early recruitment to neritic habitats. However, loggerhead turtles of Atlantic origin occurring in the western Mediterranean grow more slowly than sympatric turtles of Mediterranean origin, probably because they remain longer in oceanic habitats and hence have a reduced food supply (Piovano et al. 2011).

Adult loggerheads of both sexes remain generally neritic in the Mediterranean (Zbinden et al. 2008, 2011, Casale et al. 2013a, Luschi et al. 2013, Rees et al. 2013, 2017, Mingozzi et al. 2016, Snape et al. 2016), although oceanic foraging movement patterns have also been detected (Bentivegna 2002, Zbinden et al. 2008, Schofield et al. 2010a, Casale et al. 2012a, Hays et al. 2014b). From their neritic foraging grounds (predominantly located in the eastern basin, see Section 4.3 and Fig. 4) adults undertake periodic migrations to their breeding sites (Table 1, Fig. 5). Some adult-size loggerhead turtles occur in the foraging grounds in the western Mediterranean (Casale et al. 2012a, Luschi et al. 2013), but it is unclear whether the majority are late juveniles or reproductively active adults. The recent first observation of mating loggerhead turtles in the Gulf of Naples (SW Italy) alongside some nesting activity suggests that at least some animals may be mature adults (Maffucci et al. 2016). In any case, extensive flipper and satellite tracking of adults from their breeding areas indicate that only a minority forage in the western Mediterranean (Margaritoulis et al. 2003, Margaritoulis \& Panagopoulou 2010, Schofield et al. 2013a, Patel et al. 2015b, Snape et al. 2016). This is probably due to the low probability that hatchlings drift into the western Mediterranean (see Section 4.1) (Hays et al. 2010a, Casale \& Mariani 2014), as the distance from major rookeries to the western Mediterranean is less than the migration ceiling (maximum migration distance: $2150 \mathrm{~km}$ ) known for the species (Hays \& Scott 2013) and hence recurrent migration would be possible.

Loggerhead turtles of Atlantic origin occurring within the Mediterranean Sea probably migrate back to the Atlantic at, on average, $54.5 \mathrm{~cm}$ CCL and do not return to the foraging grounds in the Mediterranean (Revelles et al. 2007b). The return to the Atlantic is probably, at least in part, delayed by the circulation pattern at the Alboran Sea and Straits of Gibraltar (Revelles et al. 2007b). So far, only a few turtles moving from the Mediterranean to the Atlantic have been directly observed (Argano et al. 1992, Eckert et al. 2008, Revelles et al. 2008, Moncada et al. 2010, Casale et al. 2013b). 
Table 1. Main connectivity between breeding and foraging grounds for Mediterranean sea turtles Caretta caretta and Chelonia mydas (from studies including multiple individuals). Approximate minimum marine paths between areas are shown simply to provide an order of magnitude of potential migration distances. CMR: capture-mark-recapture (Margaritoulis et al. 2003, Margaritoulis \& Panagopoulou 2010, Margaritoulis \& Rees 2011, Rees et al. 2017); ST: satellite tracking (see Luschi \& Casale 2014 for references until 2013, Patel et al. 2015a,b, Stokes et al. 2015, Mingozzi et al. 2016, Rees et al. 2017)

\begin{tabular}{|c|c|c|c|c|c|}
\hline Species & Breeding site & Neritic foraging ground & Min. distance $(\mathrm{km})$ & Sex & Method \\
\hline \multirow[t]{10}{*}{ Caretta caretta } & \multirow[t]{4}{*}{ Zakynthos (Greece) } & Tunisian shelf & 800 & $\mathrm{~F}, \mathrm{M}$ & CMR, ST \\
\hline & & Adriatic & 600 & $\mathrm{~F}, \mathrm{M}$ & $\mathrm{CMR}, \mathrm{ST}$ \\
\hline & & Western Greece & $50-200$ & $\mathrm{~F}, \mathrm{M}$ & $\mathrm{CMR}, \mathrm{ST}$ \\
\hline & & Aegean & 500 & $\mathrm{~F}, \mathrm{M}$ & CMR, ST \\
\hline & \multirow[t]{2}{*}{ Rethymno (Greece) } & Libyan/Tunisian shelf & $350 / 800$ & $\mathrm{~F}$ & CMR, ST \\
\hline & & Aegean & 250 & $\mathrm{~F}$ & CMR, ST \\
\hline & \multirow[t]{2}{*}{ Cyprus } & Tunisian/Libyan shelf & 1800 & $\mathrm{~F}$ & $\mathrm{ST}$ \\
\hline & & Egypt & 500 & $\mathrm{~F}$ & $\mathrm{ST}$ \\
\hline & Libya & Tunisian shelf & 600 & M & ST \\
\hline & Italy & Tunisian shelf & 500 & $\mathrm{~F}$ & $\mathrm{ST}$ \\
\hline \multirow[t]{3}{*}{ Chelonia mydas } & \multirow[t]{3}{*}{ Cyprus } & Tunisian/Libyan shelf & 1800 & $\mathrm{~F}$ & $\mathrm{ST}$ \\
\hline & & Egypt & 500 & $\mathrm{~F}, \mathrm{M}$ & $\mathrm{ST}$ \\
\hline & & Turkey & $100-200$ & $\mathrm{~F}$ & $\mathrm{ST}$ \\
\hline
\end{tabular}

Direct information about the habitat of the green turtle early juveniles in the Mediterranean Sea is not available. Virtual particle modelling suggests that after leaving their natal beaches in the eastern Mediterranean, hatchlings remain essentially confined within the Levantine Basin (see Section 4.1) and older turtles may remain in the same area as well. The scarcity of green turtles of Mediterranean origin in the western basin (Carreras et al. 2014) is consistent with this pattern.

Green turtles settle into neritic habitats and start grazing sea grasses when they reach about $30 \mathrm{~cm}$ CCL (Cardona et al. 2010). Once they are adults, they undertake periodic breeding migrations between breeding sites and foraging grounds largely located in northern Africa and Turkey (Table 1, Fig. 6).

\subsection{Site fidelity and home ranges}

Fidelity of adult loggerhead turtles to breeding sites is a component of homing behaviour, which is indicated by the metapopulation structure resulting from genetic data (see Section 5). It has also been directly observed, mainly in females, through flipper and satellite tagging (Broderick et al. 2003, Casale et al. 2013a, Schofield et al. 2013a). However, there have been increasing observations of adults also frequenting secondary breeding sites (Schofield et al. 2010b, Casale et al. 2013a), which may have important consequences for gene flow among different rookeries.

Home ranges at breeding sites are available for loggerhead turtles in Laganas Bay, Zakynthos, Greece, where female turtles use, on average, a surface area of $10.2 \mathrm{~km}^{2}$ (range: 6-19 $\mathrm{km}^{2}$, values refer to $50 \%$ kernel estimator) (Schofield et al. 2010b). Males residing at the same site use a much smaller area of only $5.2 \mathrm{~km}^{2}\left(2.2-9.7 \mathrm{~km}^{2}, 50 \%\right.$ kernel estimator) (Schofield et al. 2010b), because they primarily patrol the area off the nesting beaches, whereas females frequent a larger area (Schofield et al. 2013b, 2017a). In Israel, inter-nesting females use much larger areas (464 km², $50 \%$ Kernel estimator) and deeper waters (up to $361 \mathrm{~m}$ depth) (Levy et al. 2017). Although home ranges have not been estimated, female turtles in Cyprus have been found to remain within an average of $20 \mathrm{~km}$ from their nesting beaches in Cyprus (Fuller et al. 2008), whereas turtles nesting in southern Calabria, on the Ionian coast of Italy, use oceanic areas with a median maximum distance from the nesting location of $145.5 \mathrm{~km}$ (Mingozzi et al. 2016). It is possible that these turtles use much larger areas to search for unevenly distributed prey in the open sea and replenish their energy stores.

Fidelity of juvenile loggerhead turtles to foraging areas is variable. For small juveniles in oceanic areas, a degree of residence in the same area has been observed in some cases through satellite tracking (Revelles et al. 2007a) and tag returns (Casale et al. 2007a), and can be explained by a mix of surface circulation patterns and active area selection (Revelles et al. 2007a). Cases of more vagile behaviour have also been observed (Bentivegna 2002, Cardona et al. 2005, 2009, Eckert et al. 2008). A stronger fidelity to neritic areas has been observed through tag returns (Casale et al. 2007a, Revelles et al. 2008) and satellite 
tracking (Cardona et al. 2009, Casale et al. 2012c). Site fidelity is even stronger in adults, as they appear to return to the same foraging ground after the reproductive migration (Godley et al. 2003, Lazar et al. 2004b, Broderick et al. 2007, Zbinden et al. 2008, Schofield et al. 2010a,b, Casale et al. 2013a), although they may also use up to 5 different foraging grounds over a period of 1 or more years (Schofield et al. 2013a). Such fidelity, combined with the disparate dispersal patterns of hatchlings from major rookeries in the eastern Mediterranean (see Section 4.1) explains why adult loggerhead turtles originating from different nesting beaches display differing probabilities of using foraging grounds in the Adriatic Sea, the Aegean Sea, the Ionian Sea or the Levantine Sea (Cardona et al. 2014, Patel et al. 2015b, Snape et al. 2016).

The above studies further showed wider home ranges for juveniles in oceanic areas when compared to neritic areas, and to a lesser extent for adults (Schofield et al. 2010a). Combining these observations with the general life-history model (see Section 4.5), Casale et al. (2012c) proposed an ecological-behavioural model of a gradual shift from a pelagic-vagile to a benthic-sedentary life style with progressive reduction of home ranges. However, some individuals, even as adults, appear to follow an alternative 'nomadic' pattern (Casale et al. 2007a, 2012a, Schofield et al. 2010a, Luschi et al. 2013, Hays et al. 2014b).

Satellite-tracking data show strong fidelity of adult green turtles to neritic foraging grounds (Broderick et al. 2007), whereas passive tags have demonstrated fidelity to nesting beaches (Stokes et al. 2014). A core home range of $464 \mathrm{~km}^{2}(50 \%$ kernel density estimate) has been reported for 1 inter-nesting female from Israel, similar to that observed for loggerhead turtles in the same area (see above). However, this home range was also more than 3 times larger than foraging home ranges (Levy et al. 2017) and the turtles tended to utilise deeper waters. This is in contrast to what has been observed in nearby Cyprus, where inter-nesting turtles tended to stay in shallow waters $(<5 \mathrm{~m})$ for $>80 \%$ of their time and travelled a maximum distance of $15.6 \mathrm{~km}$ (range: $2.5-40 \mathrm{~km}$ ) (Fuller et al. 2008, 2009). Such variations in area use are most plausibly explained by the responses of females to the presence of males, or whether they are foraging during the internesting period. Home ranges at foraging grounds range from 12 to $137 \mathrm{~km}^{2}$ (Godley et al. 2002b, Broderick et al. 2007, Stokes et al. 2015, Levy et al. 2017).

\subsection{Seasonal and breeding migrations, mating and nesting}

Data on seasonality and periodicity of breeding behaviours (breeding season, migratory periods, remigration interval) are provided in Table 2. Male loggerhead turtles tend to migrate more often than females (Table 2). The males that show a longer remigration interval to Zakynthos (Greece) tend to forage along the coast of Africa or the west Mediterranean (Hays et al. 2014b), potentially reflecting a poorer resource availability than in northern foraging areas (Patel et al. 2015b).

Females have been observed exhibiting strong male avoidance behaviours (Schofield et al. 2006), while multiple paternity analyses have shown that this population exhibits some of the highest levels of multiple paternity for the size of the population globally (Zbinden et al. 2007b, Lee et al. 2017). This is probably because turtles aggregate close to the shore, increasing encounter rates (Lee et al. 2017). Multiple pater-

Table 2. Seasonality and periodicity of Mediterranean sea turtle (Caretta caretta and Chelonia mydas) reproduction. Values represent medians or means. 1: Broderick et al. (2003), Ilgaz et al. (2007), Hays et al. (2010b); 2: Hays et al. (2010b), Casale et al. (2013a), Hays et al. (2014b); 3: Margaritoulis et al. (2003); 4: Schofield et al. (2006, 2017a); 5: Hays et al. (2010b, 2014b), Schofield et al. (2010a, 2013b), Casale et al. (2013a).; 6: Zbinden et al. (2008), Mingozzi et al. (2016), Hays et al. (2010b); 7 : Erk'akan (1993), Baran \& Türkozan (1996), Broderick \& Godley (1996), Türkozan (2000), Margaritoulis \& Rees (2001), Margaritoulis (2005), Margaritoulis et al. (2011a); 8: Stokes et al. (2014); 9: Wright et al. (2012a); 10: Broderick et al. (2002); 11: Stokes et al. (2015); 12: Broderick \& Godley (1996). (-) No data available

\begin{tabular}{|lccc|}
\hline & Caretta caretta & Source & Chelonia mydas \\
\hline Remigration interval for females (yr) & $2-3.35$ & 1 & 3 \\
Remigration interval for males (yr) & $1-1.8$ & 2 & $>1$ \\
Renesting interval (d) & $12.7-19.9$ & 3 & 12.5 \\
Mating period (peak) & Apr-May & 4 & - \\
Male breeding migrations (to/from breeding site) & Oct-Apr / May-Jun & 5 & - \\
Female breeding migrations (to/from breeding site) & Apr-May / Jul-Aug & 6 & $-/$ Jul-Sep \\
Nesting season (peak) & Jun-Jul & 7 & Jun-Jul \\
\hline
\end{tabular}


nity has also been found in Dalyan (Turkey) (Sari et al. 2017) and Alagadi (Alakati), Cyprus (Wright et al. 2012b).

Female nesting activity (e.g. total and nesting emergences) has been found to be dependent on beach width in Zakynthos, Greece (Mazaris et al. 2006) and also to be affected by the sea surface temperature of the current and previous years (Mazaris et al. 2004). Adults have been observed using fish-cleaning stations during the nesting season in Zakynthos, Greece (Schofield et al. 2017b).

There is considerable geographical variation in the temporal distribution of nesting activity between eastern (e.g. Turkey) and western (e.g. Greece) nesting areas, with nesting starting and terminating earlier in the eastern areas (Margaritoulis \& Rees 2001).

Seasonal changes in sea water temperature do not elicit seasonal migrations in most areas (Casale et al. 2012a, Luschi et al. 2013), except in the northern parts of the western Mediterranean (Bentivegna 2002, Lauriano et al. 2011) and in the northern Adriatic Sea (Zbinden et al. 2008, 2011, Casale et al. 2012a, Schofield et al. 2013a). Still, as reviewed by Luschi \& Casale (2014) and in accordance with observations by Hochscheid et al. (2007), some turtles, including juveniles, overwinter in waters where temperatures fall below $13^{\circ} \mathrm{C}$, thus remaining at northern latitudes rather than migrating south. On a smaller scale, loggerhead turtles move from shallow summer feeding areas into deeper offshore areas during the winter (Broderick et al. 2007, Casale \& Simone 2017). Seasonal movements between the western, central and eastern basins have also been suggested (Camiñas \& De La Serna 1995, Bentivegna 2002).

Data on seasonality and periodicity of breeding behaviours of green turtles are provided in Table 2 . Green turtles move from shallow summer feeding areas into deeper offshore areas during the winter (Broderick et al. 2007).

\subsection{Swimming, orienting and diving}

Juvenile loggerhead turtles larger than $41 \mathrm{~cm}$ CCL foraging in oceanic zones have been recorded travelling at speeds of $0.7 \mathrm{~km} \mathrm{~h}^{-1}$ on average, and adults of both sexes migrating from their breeding areas to their foraging grounds travel at $1.4 \mathrm{~km} \mathrm{~h}^{-1}$ on average (see Table S12 in the Supplement). Adult loggerhead turtles travel faster by day than by night both in oceanic and neritic waters (Dujon et al. 2017). When in the neritic, both juveniles and adults appear to decrease their speed to $0.4 \mathrm{~km} \mathrm{~h}^{-1}$ (see Table S12), which may however be confounded by errors associated with low accuracy ARGOS location classes (Witt et al. 2010a). More accurate Fastloc-GPS tags can deliver better estimates for speed of travel (Witt et al. 2010a), but they have only recently been used in the Mediterranean and for now confirm lower speeds of travel in the neritic foraging areas (Dujon et al. 2017). Currents seem to have no obvious influence on the movement of large juveniles (Bentivegna et al. 2007) or adults (Mingozzi et al. 2016), whereas they determine the movement of small juveniles (Revelles et al. 2007a,b,c, Cardona \& Hays 2018). Higher resolution data for both current and turtle speeds are needed to elucidate the fine-scale interplay between these factors.

Insights into the orientation of loggerheads in the Mediterranean are provided by the few tracking data of pre-breeding migration (Zbinden et al. 2008, Hays et al. 2010b, Schofield et al. 2010a, Casale et al. 2013a, Mingozzi et al. 2016, Snape et al. 2016) and also by some of the post-breeding migrations showing fidelity to specific foraging areas (see Section 4.6). Departure from and arrival at breeding, stopover and foraging sites have been found to occur during the daytime, which is consistent with the use of solar visual cues for orientation (Dujon et al. 2017). Although loggerhead turtles in the Mediterranean are faithful to their nesting and foraging grounds (see Section 4.6), they do not necessarily follow the optimal routes, but rely on course corrections when entering neritic waters during the final stages of migration (Hays et al. 2014a). The consistency of the migratory route has been shown to be relatively strong when oceanic crossing is comparatively direct (Broderick et al. 2007) but consistently lower when turtles travel further in open waters (Schofield et al. 2013a).

Diving statistics are provided in Table S13 in the Supplement. Surface time for loggerhead turtles inhabiting oceanic areas during daylight hours peaks in spring (65\%) and drops in late summer (25\%), and the change is thought to be the result of seasonal changes in the relative availability of neustonic gelatinous plankton (Revelles et al. 2007a) and the thermal biology of turtles. Time underwater and activity vary seasonally, and single dives can last several hours in winter when water temperatures fall below $15^{\circ} \mathrm{C}$ and turtles go into a quiescent period during which they mainly rest on the seafloor (Hochscheid et al. 2005, 2007, Broderick et al. 2007). These dormant turtles are more prone to bycatch by bottom trawlers (Casale et al. 2004, Domènech et al. 2015) because their low metabolism at cooler temperatures makes them slow to respond to such threats (Hochscheid et al. 2004). 
Speed of travel of migrating green turtles is summarised in Table S12 and appears to be higher in the oceanic than in the neritic part of the migration. Once at their foraging grounds, adult green turtles move slowly, but figures on speed of travel remain unpublished (Godley et al. 2002b, Broderick et al. 2007, Stokes et al. 2015). Diving statistics are provided in Table S13.

\subsection{Diet and foraging behaviour}

While in oceanic habitats, loggerhead turtles are diurnal predators (Revelles et al. 2007a), roaming over extensive areas (Cardona et al. 2005, Revelles et al. 2007a,c, Luschi et al. 2018) and spending most of their time close to the surface (see Table S13). They rely primarily on gelatinous plankton (jellyfish and tunicates), although fish and squid can also supplement their diet (see Table S14 in the Supplement). Some data on nocturnal foraging have shown that larger individuals may reach and prey upon vertically migrating animals (Hochscheid et al. 2010). These turtles even dive beyond their calculated aerobic limits, probably by switching to anaerobic metabolism to maximise time within food patches.

When foraging on the sea bed, larger juvenile and adult loggerhead turtles favour invertebrates such as crabs and hermit crabs (e.g. Liocarcinus vernalis and Portunus hastatus), bivalves (e.g. Mytilus galloprovincialis), gastropods (e.g. Bolinus brandaris) and cephalopods (e.g. Sepia officinalis) (see Table S14). In some areas, they may also consume large amounts of fish discarded by fishing vessels (Houghton et al. 2000, Tomás et al. 2001). When loggerheads forage for benthic molluscs, they actively stir the sediments and crush the shells of their prey into smaller fragments, thus playing an important role as bioturbators (Lazar et al. 2011a). In the shallow sandy habitats of the central Tyrrhenian Sea, a large juvenile showed diurnal feeding with peak activity during early morning and late afternoon (Hochscheid et al. 2013). Adults have been observed foraging at a nesting site while aggregating during the breeding season (Schofield et al. 2006).

Dive profiles have indicated that loggerhead turtles remain active at temperatures as low as $11.8^{\circ} \mathrm{C}$ (Hochscheid et al. 2007), and satellite-tracking data show horizontal movements in winter even in the northernmost part of the Adriatic (Casale et al. 2012a). This suggests that turtles may generally feed during the winter in the Mediterranean, although exceptions in particularly cold areas cannot be ex- cluded. Direct evidence of winter feeding has been reported in Tunisia (Laurent \& Lescure 1994).

There is a dearth of information on the ecology of oceanic juvenile green turtles in the Mediterranean, but stable isotope analyses from the eastern basin suggest a diet similar to loggerhead turtles (Cardona et al. 2010). Stable isotopes and gut content analyses indicate that they have mixed diets until they reach some $60 \mathrm{~cm}$ CCL, when they become primarily herbivores (Demetropoulos \& Hadjichristophorou 1995, Godley et al. 1998, Cardona et al. 2010, Lazar et al. 2010). Green turtles do not consume the abundant seagrass Posidonia oceanica, but rely mainly on the scarcer Cymodocea nodosa (see Table S14), which grows primarily in shallow, sheltered bays. This explains why this is the major habitat for green turtles in the eastern Mediterranean and why they usually forage at depths less than $5 \mathrm{~m}$ (Godley et al. 2002b, Hays et al. 2002, Broderick et al. 2007, Stokes et al. 2015).

\subsection{Gaps and priorities}

In conclusion, there are many significant gaps in the current knowledge of sea turtle distribution and behaviour in the Mediterranean. Empirical data are almost completely lacking regarding nursery areas, and are scarce regarding oceanic habitats of small juveniles, especially of green turtles, and for the Levantine Basin for both species. Satellite tracking is unveiling important distribution and behavioural patterns in those size classes where it is possible. It is a very promising approach for improving our knowledge of habitat utilisation, connectivity, migratory routes and behaviour, with strong conservation implications. There is, however, a need to extend the approach to adults at different sites, and juveniles, smaller and smaller as technology miniaturises, especially in the eastern basin. Tracking small juveniles will be facilitated by the availability of increasingly smaller devices. This should be complemented by aerial surveys to assess the relative abundance of turtles among areas. Moreover, better genetic markers, and additional stable isotope studies and diet analyses may all help enhance our understanding.

\section{POPULATION STRUCTURE AND DYNAMICS}

A detailed knowledge of demographic units and demographic parameters is a prerequisite to population modelling which can help determine the key 
drivers of population dynamics and consequently the best conservation strategies. Mazaris et al. (2005) suggested a relatively high importance of fecundity and of early juvenile survival for loggerhead turtle population dynamics, in contrast to the previous and prevailing opinion of a higher importance of the older life stages (e.g. Crouse et al. 1987, Heppell et al. 2003). According to Mazaris et al. (2009b), the proportion of eggs that hatch in a successful clutch is of greater importance than the proportion of clutches that hatch. Casale \& Heppell (2016) constructed a theoretical demographic structure of the Mediterranean populations of both species, assuming a stationary age distribution, and provided a likely order of magnitude of population abundance as a whole, as well as at different life stages (see Section 6).

\subsection{Metapopulation structure}

The Mediterranean Sea is frequented by loggerhead turtles belonging to 3 independent RMUs (Wallace et al. 2010): the Mediterranean, the northwest Atlantic and the northeast Atlantic (Monzón-Argüello et al. 2010, Wallace et al. 2010). Only individuals from the Mediterranean RMU breed in the region. The species colonised the area during the Pleistocene (Clusa et al. 2013) through different colonising events (Garofalo et al. 2009), and thus the regional population survived several cold periods using warm refuges across the south-eastern parts of the sea (Clusa et al. 2013). Nesting populations are well structured, due to female philopatry, and 7 independent Management Units (MUs) have been identified within the region using mitochondrial DNA (mtDNA) markers (Shamblin et al. 2014): (1) Calabria, Italy, (2) western Greece (Zakynthos + Kyparissia + Lakonikos), (3) Rethymno (Crete, Greece), (4) Dalyan + Dalaman (Turkey), (5) western Turkey (Fethiye to Çıralı), (6) eastern Mediterranean (central + eastern Turkey + Lebanon + Israel + Cyprus) and (7) Libya + Tunisia

Additionally, loggerhead males are also philopatric, although some male-mediated gene flow has been proposed among different populations that may help the maintenance of the genetic variability of the smallest populations (Schroth et al. 1996, Carreras et al. 2007, Yilmaz et al. 2011, Clusa et al. 2018). Accordingly, the use of multiple breeding sites by males during the breeding season has been documented by 2 studies, with males frequenting up to 5 alternative breeding areas in a single region (Casale et al. 2013a, Schofield et al. 2013a). Recently, it has been suggested that the structuring found in the Mediterran- ean could also be driven by local adaptation, as the 3dimensional variations of the mitochondrial ND1 and ND3 genes are thought to be linked to thermal adaptation (Novelletto et al. 2016). Despite this marked genetic structuring at nesting beaches, the individuals hatched at different sites have high mobility within the Mediterranean and commonly share foraging grounds (see Section 4). This sharing of foraging grounds may explain the moderate levels of male-mediated gene flow found within the Mediterranean through opportunistic mating, although Mediterranean turtles remain differentiated from individuals coming from Atlantic RMUs (Carreras et al. 2011).

The Mediterranean green turtle population represents an independent RMU (Wallace et al. 2010). So far, there are no data in support of genetic structuring within this RMU, in spite of the fact that the species shows one of the highest levels of female philopatry among turtles (Miller 1997), leading to generally well-structured populations in other regions (Encalada et al. 1996, Naro-Maciel et al. 2014). In the Mediterranean, several studies have highlighted the lack of resolution in the mitochondrial DNA markers due to the over-dominant presence of a single haplotype. Thus, almost all Mediterranean individuals bear this same haplotype, which results in a failure to detect the structuring expected for this highly philopatric species (Kaska 2000, Bagda et al. 2012, Naro-Maciel et al. 2014). This, combined with possible male-mediated gene flow between reproductive populations (Wright et al. 2012b), may lead to a failure in detecting population structuring. However, new promising mitochondrial markers have been tested on Mediterranean green turtles (Tikochinski et al. 2012) and suggest a much deeper structuring in the Mediterranean than previously thought, even though they have not yet been applied to the whole region. A similar lack of structuring has been found with nuclear markers worldwide, suggesting general male-mediated gene flow even among different RMUs (Roberts et al. 2004). This study has been quoted in support of the retraction of the Mediterranean green turtle region as an isolated unit for conservation purposes (Mrosovsky 2006), even though other authors have suggested that this worldwide assessment could lack the resolution required to detect differentiation at regional levels (Naro-Maciel \& Formia 2006). In fact, some recent regional studies using a larger set of markers have shown a clear structuring among the north-eastern Mediterranean populations and within Cypriot populations that contradicts this worldwide assessment (Bagda et al. 2012, Bradshaw et al. 2018), 
thus indicating that a deep structuring may exist in the region. In conclusion, detailed knowledge of green turtle population structuring in the Mediterranean is still incomplete due to a lack of resolution of most of the nuclear and mitochondrial genetic markers used but also to the incomplete analysis of all known nesting areas.

\subsection{Population demography}

\subsubsection{Reproductive output}

Data on clutch size, and hatchling emergence success of both loggerhead and green turtles are summarised in Table S15 in the Supplement. Substantial differences exist in terms of clutch sizes of loggerhead turtles within the Mediterranean, with the smallest females and clutch sizes observed in Cyprus and the largest females and clutch sizes observed in Greece (see Tables S1 \& S15). Furthermore, great variation in clutch size may exist within a single rookery. This has been attributed to differing migration and foraging areas of the nesting females, with different areas providing different trophic resources (Zbinden et al. 2011, Cardona et al. 2014, Patel et al. 2015b).

At Alagadi (Alakati), Cyprus, the number of clutches laid per season by loggerhead turtles ranges between 1 and 5 (Broderick et al. 2003), and this parameter may be associated with re-nesting interval (see Section 4), while in green turtles the median number of clutches laid per female each season is 3 (interquartile range: 1-4) (Stokes et al. 2014).

Values of hatchling emergence success (see Table S15) should be treated with caution, because they are derived from only a few nesting sites, from different groups of nests (both protected and unprotected), and because the beach mortality between the emergence of hatchlings and their entrance into the sea is not always taken into account or may vary greatly.

\subsubsection{Development, growth and age at sexual maturity}

The incubation duration of loggerhead turtle clutches is negatively correlated with nest temperature (Godley et al. 2001a, Mrosovsky et al. 2002, Kaska et al. 2006) and is highly variable among the Mediterranean beaches (see Table S15). Viable hatchlings from nest temperatures as low as $26.5^{\circ} \mathrm{C}$ (with an incubation duration up to $79 \mathrm{~d}$ ) have been recorded in Sicily, Italy (Casale et al. 2012d), whilst the longest incubation duration in the Mediterranean (89 d) has been recorded twice on Marathonissi Beach (Laganas Bay, Zakynthos) (Margaritoulis 2005, Margaritoulis et al. 2011a). At the opposite end of the range, nest temperatures as high as $33.2^{\circ} \mathrm{C}$ in Cyprus (Godley et al. 2001a) and an incubation duration as low as 36 d in Calabria, Italy (Mingozzi et al. 2007) have been observed.

Information on growth rates of loggerhead turtles is provided in Table 3 and Table S16 in the Supplement. Mediterranean loggerheads appear to reach $28 \mathrm{~cm}$ CCL at about $3.5 \mathrm{yr}$ of age, with growth rates similar to Atlantic turtles (Casale et al. 2009a) (see Table S16). Broderick et al. (2003) observed non-negligible growth of loggerhead females nesting in Cyprus (see Table S16). Different foraging grounds appear to affect carapace length and clutch size

Table 3. Age at maturity and growth rates of Caretta caretta in the Mediterranean Sea. ASM: age at sexual maturity; CCL: curved carapace length; CMR: capture-mark-recapture; $k$ : von Bertalanffy growth coefficient; $L_{\infty}$ : asymptotic length; LFA: length frequency analysis; SKE: skeletochronology

\begin{tabular}{|c|c|c|c|c|c|c|c|c|c|}
\hline Area & $\begin{array}{l}\text { CCL } \\
(\mathrm{cm})\end{array}$ & $\mathrm{N}$ & $\begin{array}{l}\text { Growth rates } \\
\left(\mathrm{cm} \mathrm{yr}^{-1}\right) \\
\text { mean } \pm \mathrm{SD} \\
\text { (min.-max.) }\end{array}$ & $\begin{array}{c}\text { Size at } \\
\text { maturity } \\
(\mathrm{CCL}, \mathrm{cm})\end{array}$ & $\begin{array}{l}\text { ASM (yr) } \\
(95 \% \text { CI })\end{array}$ & Method & $\begin{array}{c}k\left(\mathrm{yr}^{-1}\right) \\
(95 \% \mathrm{CI})\end{array}$ & $\begin{array}{c}L_{\infty} \\
(\mathrm{cm})\end{array}$ & Source \\
\hline Mediterranean & $32.5-86.0$ & 38 & $\begin{array}{l}2.5 \pm 1.7 \\
(0-5.97)\end{array}$ & $66.5-84.7$ & $16-28$ & CMR & 0.077 & 95.63 & Casale et al. (2009b) \\
\hline $\begin{array}{l}\text { Central } \\
\text { Mediterranean }\end{array}$ & $20-88$ & 774 & $(0.37-6.5)$ & $66.5-84.7$ & $\begin{array}{l}15.4-27.8 \\
18.8-34.9\end{array}$ & LFA & $\begin{array}{l}0.066 \\
0.051\end{array}$ & $99^{\mathrm{a}}$ & Casale et al. (2011b) \\
\hline $\begin{array}{l}\text { Central } \\
\text { Mediterranean }\end{array}$ & $24-86.5$ & 33 & $1.41-6.17$ & $66.5-84.7$ & $\begin{array}{l}16.2-28.5 \\
14.9-26.3\end{array}$ & SKE & $\begin{array}{l}0.066 \\
0.072\end{array}$ & $99^{\mathrm{a}}$ & Casale et al. (2011a) \\
\hline Italian waters & $4.2-76$ & 30 & $0.4-8.6$ & 69 & $24(21-27)$ & SKE & $\begin{array}{c}0.042 \\
(0.036-0.049)\end{array}$ & $99^{\mathrm{a}}$ & Piovano et al. (2011) \\
\hline
\end{tabular}


(Zbinden et al. 2011, Schofield et al. 2013a, Cardona et al. 2014, Patel et al. 2015b) and this suggests a nutritional effect. As the Mediterranean is a shared marine habitat frequented by turtles from distant populations, growth rates may not depend solely on the environmental conditions (e.g. productivity and temperature) and turtle size at the time of recruitment at different habitats, but may also be influenced by the origin of the individuals (Piovano et al. 2011). Although growth rates decline with size/age (see Table S16), loggerheads of Mediterranean origin exhibit higher mean growth rates than individuals from Atlantic populations sharing the same Mediterranean habitats. This suggests that mature females nesting in the Mediterranean are not only smaller than those from the western North Atlantic, but they may also be younger (Piovano et al. 2011).

Age at sexual maturity (ASM) of loggerhead turtles has been estimated through growth models applied to size at maturity, assumed to be the average size of nesting females. Different aging methods have resulted in similar estimations of ASM, ranging from 14.9 to $18.8 \mathrm{yr}$ for small nesters of $66.5 \mathrm{~cm}$ CCL and 26.3 to $34.9 \mathrm{yr}$ for larger reproductive females of $84.7 \mathrm{~cm}$ CCL (Table 3). However, the mean size (weighted for rookery size in terms of number of nests) of female loggerhead turtles nesting in the Mediterranean is $79.1 \mathrm{~cm}$ CCL (see Table S17 in the Supplement) and males appear to reach maturity at a similar size (Casale et al. 2005, 2014). The average ASM for the Mediterranean loggerhead population has been estimated to be 25 yr (range: 21-34 yr) using the mean values of 8 age-at-length relationships obtained by the above studies applied to a size at maturity of $80 \mathrm{~cm}$ CCL (Casale \& Heppell 2016).

In green turtles, mean incubation durations range from 49 to $60 \mathrm{~d}$ (see Table S15). Clutch temperatures range from $28.3^{\circ} \mathrm{C}$ with an incubation period of $59 \mathrm{~d}$ in Turkey (Candan \& Kolankaya 2016) to as high as $32.5^{\circ} \mathrm{C}$ with an incubation period of $43 \mathrm{~d}$ in Cyprus (Kaska et al. 1998, Broderick et al. 2000). Current information on growth rates is limited to adult females showing a slow growth of $0.11 \mathrm{~cm} \mathrm{CCL} \mathrm{yr}^{-1}$ (Broderick et al. 2003), while age at sexual maturity has yet to be established.

\subsubsection{Sex ratio}

The pivotal temperature (egg incubation temperature at which both sexes are produced in equal numbers) for Mediterranean loggerheads assessed in laboratory and field conditions is about 29 to $29.3^{\circ} \mathrm{C}$ and similar to other populations elsewhere, with a pivotal incubation duration (at which both sexes are produced in equal numbers) of $53 \mathrm{~d}$ from laying to hatching (Kaska et al. 1998, Mrosovsky et al. 2002). Other studies under natural conditions (Fuller et al. 2013) found a slightly lower $\left(28.9^{\circ} \mathrm{C}\right)$ pivotal temperature and longer incubation duration than expected (56.3 d), due to the effect of metabolic heating generated by the whole nest.

By applying different indirect sex determination methods, loggerhead hatchling production at most Mediterranean nesting sites appears likely to be highly female biased (see Table S18 in the Supplement), with the major rookeries in Greece, Turkey, Libya and Cyprus producing 60 to $99 \%$ females. Interestingly, gonadal histology as a direct sexing method, although possibly biased by the field sampling protocols and applied only in a limited number of cases, showed less skewed loggerhead hatchling sex ratios (55.6 to $79 \%$ females; see Table S18). Male-biased hatchling production occurs at least in some sites, such as Marathonissi beach in Zakynthos, Greece (Margaritoulis 2005, Zbinden et al. 2007a, Margaritoulis et al. 2011a) and Kuriat Island in Tunisia (Jribi \& Bradai 2014), and may be possible at other sites in some years (e.g. Lakonikos Bay in Greece; Dalyan, Kizilot and Patara in Turkey) (Godley et al. 2001b).

Temporal variations in sex ratios have also been reported (Kaska et al. 2006, Katselidis et al. 2012, Fuller et al. 2013), with more male hatchlings being produced from the nests laid at the beginning and the end of the nesting season (nests laid in May and August, respectively), than from those laid in the middle of nesting season (June and July). Rain can also play a role in such seasonal differences (Katselidis et al. 2012). The eggs at the top of a nest are also likely to produce relatively more females than those at the bottom of a nest (Kaska et al. 1998). The beach sand colour (albedo), sand grain size, shading from vegetation etc. seem to be important factors in determining hatchling sex ratios (e.g. Kaska et al. 1998, Hays et al. 2001, Zbinden et al. 2007a, Fuller et al. 2013).

Surprisingly, and contrary to predominant femalebiased hatchling production, a lower proportion of females among juvenile loggerhead turtles (52 to $56 \%$ ) has been observed in 5 distant Mediterranean marine habitats, spanning from the western basin to the Adriatic (see Table S18 and references therein). Initially, a discrepancy between strong female-biased hatchling production and almost even sex ratios in juvenile loggerheads was explained by a strong male-biased immigration of Atlantic juveniles in the 
Mediterranean Sea (Casale et al. 2002, 2006). However, an equal sex ratio found in the north-central Adriatic Sea, an area with no Atlantic contributors (Garofalo et al. 2013, Maffucci et al. 2013, Clusa et al. 2014), and a strong female-bias (2:1) in juvenile assemblages from the Atlantic Ocean (Wibbels 2003, Delgado et al. 2010) provided little support for this hypothesis. An overall female bias in the juvenile sex ratio $(1.56: 1)$ was recorded in a long-term study in the Tyrrhenian Sea, although in some years this ratio was more balanced (Maffucci et al. 2013). As juveniles represent a condensation of different cohorts with different sex ratios, originating from different source populations, there are several plausible and probably interconnected explanations for such sex ratio dynamics in the Mediterranean. For example, a female bias in hatchling production may be greatly overestimated (Delgado et al. 2010), as the details of the temperature sex determination (TSD) mechanism remain unclear (Wibbels 2003), and hatchling production in the Mediterranean may exhibit significant intra- and inter-annual variation in sex ratios (Godley et al. 2001b, Katselidis et al. 2012). Contribution of different source populations to juveniles in marine habitats may also change between years, as well as sex-specific mortality rates, behaviour and spatial distribution (Maffucci et al. 2013). At present, it seems that the juvenile loggerhead sex ratio in the Mediterranean could be female biased, although to a lesser extent than that of the Atlantic stock, but long-term assessments in other marine areas are needed to compensate for the effect of spatio-temporal variability (Maffucci et al. 2013).

Adult sex ratios at different loggerhead foraging grounds range from female to male biased (see Table S18 and references therein). Although sex determination in adults is possible by external sexual characteristics (bimodal distribution of tail lengths at $>75 \mathrm{~cm} \mathrm{CCL}$ ) (Casale et al. 2005), their low abundance makes such studies challenging. Moreover, sex-specific behaviour and breeding periodicity may influence the results. Male bias in the Amvrakikos Gulf (Greece) between May and September (Rees et al. 2013), and in the central Mediterranean from June to September (Casale et al. 2014) may be explained by fewer females being present at foraging grounds during the reproductive season. Inversion of the sex ratios from female biased in juveniles to male biased in adults in the Tyrrhenian Sea is intriguing and deserves further investigation (Casale et al. 2014). Operational sex ratio may have profound implications for understanding sea turtle population viability at skewed sex ratios (Hays et al. 2017), but in the
Mediterranean, this has only been estimated in Zakynthos (Greece), where an overall balanced operational sex ratio was suggested, although it was highly variable during the breeding season (Hays et al. 2010b, 2014b, Schofield et al. 2017a).

Primary sex ratios of green turtles tend to be female biased (see Table S18). No information is available at present on juvenile and adult sex ratios of green turtles at foraging areas. An overall operational sex ratio of $1.4 \mathrm{M}: 1 \mathrm{~F}$ was estimated from a genetic paternity study at Alagadi (Alakati) Beach, Cyprus (Wright et al. 2012b).

\subsubsection{Survival probabilities}

So far, no information is available on survival probabilities of green turtles, while 2 studies have investigated survival probabilities of loggerhead turtles (see Table S19). One study using capture-mark-recapture data probably underestimated annual survival probability $(0.73)$ by at least 0.1 because of tag loss (Casale et al. 2007b). The second study estimated annual survival probabilities of large juveniles at 4 different foraging areas through a catch curve analysis, and the resulting relatively low values (range: $0.71-0.86$ depending on the area) were considered to probably be due to anthropogenic mortality such as bycatch, especially in some areas such as the south Adriatic (Casale et al. 2015).

\subsection{Gaps and priorities}

In conclusion, our knowledge about metapopulation structure may have reached a limit due to the available genetic markers, and a better picture can only come from developing better markers. Although some information is starting to become available on certain demographic parameters - although only of loggerhead turtles - this is still insufficient for the purposes of demographic models, which would have strong conservation implications. Age at sexual maturity, survival probabilities, sex ratio and reproductive output are priority parameters for future research in both species and especially in green turtles (Rees et al. 2016).

\section{POPULATION ABUNDANCE AND TRENDS}

Sea turtle populations mainly consist of juveniles of small size which never come ashore (Heppell et al. 
2003). Consequently, the empirical estimate of the number of juveniles is extremely challenging. For instance, while aerial surveys can estimate the number of turtles at the surface (at least those large enough to be seen from an aircraft) and the total number can then be extrapolated if the proportion of time spent at the surface is known from other sources (e.g. satellite tracking; see Section 6.1 for case studies), this approach cannot be realistically conducted comprehensively across the whole region. Therefore, it is unlikely that it can estimate the abundance of the entire Mediterranean populations.

Nesting female sea turtles and especially their clutches have been used as indices of population size and trends for well over half a century worldwide (Carr 1954, Pritchard 1982, Bjorndal et al. 1999, Broderick et al. 2002, Margaritoulis 2005, Türkozan \& Yilmaz 2008, Mazaris et al. 2017). Due to the extended time frames involved in sea turtle life histories, long systematic beach monitoring over multiple successive years is needed (Jackson et al. 2008, Mazaris et al. 2017). In the Mediterranean region, the first systematic sea turtle monitoring programmes began in the late 1970s (Geldiay et al. 1982, Margaritoulis 1982, Demetropoulos \& Hadjichristophorou 1989).

Nesting activity (nest counts) can be converted into adult population size estimates, provided that 3 demographic parameters are known (number of clutches laid by a female in a nesting season, years between nesting seasons and adult sex ratio) (e.g. Casale \& Heppell 2016). However, these parameters are difficult to estimate and have great uncertainty (Mazaris et al. 2008b, Tucker et al. 2013). Therefore, any result derived from nest counts should be regarded with caution.

\subsection{Abundance}

The 52 major nesting locations of loggerhead turtles (see Table S9) have held an average total of 6751 clutches per year. This figure is based on data obtained over a long time span, during which monitoring improvement and changes in nesting levels may have occurred. Therefore, as an attempt to provide a figure as close as possible to the contemporary nesting levels, we calculated the average number of clutches from the most recent $5 \mathrm{yr}$ period in each nesting site, resulting in 8179 clutches per year (see Table S9 for year ranges). However, this figure should be regarded as a minimum, because nesting also occurs at other, non-monitored, nesting sites, including scattered nesting over most of the Mediter- ranean, and some promising long coastal tracts have never been surveyed. For instance, $66 \%(1089 \mathrm{~km})$ of the Libyan sandy coast has yet to be adequately surveyed (Hamza 2010). From these nest counts, which have the serious limitations mentioned, and other parameters which also suffer from profound gaps and limitations like clutch frequency (the number of clutches laid by a female in a nesting season), the remigration interval (number of years between 2 consecutive nesting seasons) and adult sex ratio (see Sections 4 \& 5), Casale \& Heppell (2016) estimated a total of 15843 adults (95\% CI: 6915-31 958).

Abundance estimates of loggerhead turtles at sea, where juveniles represent the majority of the population, have been conducted through several spatially limited aerial surveys. These include the oceanic waters off Spain (Gómez de Segura et al. 2006), the continental shelf around the Balearic Islands (Spain) (Cardona et al. 2005) and the northern Tyrrhenian Sea (Lauriano et al. 2011), which are all in the western Mediterranean. Estimated total numbers in these areas were 18954 (95\% CI: 6679-53786), 437 and approximately 10000 turtles (in summer), respectively. Since green turtles are very rarely found in the western Mediterranean (see Section 4), these figures refer to loggerhead turtles only. However, aerial census studies are restricted to 1 or a few years of effort, limiting the capacity to determine inter-annual variability and trends, hence overestimating or underestimating population sizes depending on the years and seasons surveyed.

Extrapolating the number of juveniles from nest counts, through adult numbers, would require a deep knowledge of demography and also several assumptions. By assuming a stationary stage distribution of the population and incorporating uncertainty of the several demographic parameters involved, Casale \& Heppell (2016) attempted to provide at least the order of magnitude of a possible range of values for the total loggerhead turtle population abundance (including adults): from 1197087 (95\% CI: $805658-$ 1732675 ) to 2364843 (95\% CI: $1611085-3376104$ ).

The 13 major nesting locations of green turtles (see Table S11) have held an average total of 1650 clutches per year if all surveyed years are included, while the most recent available data provide an average of 2204 nests per year (see the discussion of loggerheads above for explanations and Table S11 for year ranges). However, this figure should be regarded as a minimum, because nesting may also occur in other, non-monitored nesting sites, including scattered nesting. From these nest counts, the clutch frequency (the number of clutches laid by 
a female in a nesting season), the remigration interval (number of years between 2 consecutive nesting seasons) and adult sex ratio (see Sections 4 \& 5), Casale \& Heppell (2016) estimated 3390 adults (95\% CI: 1894-6552).

There are no at-sea abundance estimates for green turtles so far. As described above for loggerhead turtles, Casale \& Heppell (2016) attempted to provide at least the order of magnitude of a possible range of values for the total green turtle population abundance (including adults): from 261727 (95\% CI: $176284-391386$ ) to 1252283 (95\% CI: 679 433-2 209 833).

\subsection{Population trends}

With the necessary caution due to the poor quality of nest counts as an index for the entire population, a rough comparison of average nest counts of loggerhead turtles at 21 nesting sites between 2 arbitrary periods (up to and including 1999 and from 2000 onwards, with the first roughly corresponding with the period covered by previous reviews) indicates an overall positive trend (Table 4). A more accurate comparison between past and recent nest counts at 16 index nesting sites was included in a recent IUCN Red List assessment of the Mediterranean subpopulation, which also reported a positive trend (Casale 2015) as did Mazaris et al. (2017). However, these index sites account for just a segment of the total nest counts in the monitored sites, and not all of the nesting activity in the Mediterranean is monitored. Additional caution is needed because long-term monitored sites have likely benefitted from long-term conservation programmes and protection status, and may therefore not be wholly representative.

Abundance and trend data from index marine sites are still lacking. The long-term monitoring of bycatch data relating to specific fishing gear (e.g. Albania) (Haxhiu 2010) may provide trend indices, and a few in-water monitoring programmes have been set up, for instance in Amvrakikos Gulf, Greece (Rees et al. 2013, 2017). However, to our knowledge, the only information about in-water trends at present is repre-
Table 4. Trends in nesting activity of sea turtles in the Mediterranean Sea. Average annual number of nests from 2 periods are compared: before 1999 and after 2000. The dataset of the first period roughly corresponds with previous re(2003) and Kasparek et al. (2001) on loggerhead Caretta caretta and green Chelonia mydas turtles, respectively. Only nesting sites with data from at least 5 nesting seasons in each period are included. See

\begin{tabular}{|c|c|c|c|c|}
\hline \multirow{2}{*}{$\begin{array}{l}\text { Species } \\
\text { Country }\end{array}$} & \multirow[t]{2}{*}{ Nesting site } & \multicolumn{2}{|c|}{ Average nests $\mathrm{yr}^{-1}$} & \multirow{2}{*}{$\begin{array}{c}\text { Change } \\
(\%)\end{array}$} \\
\hline & & Before 1999 & After 2000 & \\
\hline \multicolumn{5}{|c|}{ Caretta caretta } \\
\hline \multirow[t]{7}{*}{ Cyprus } & $\begin{array}{l}\text { Akdeniz Beaches } \\
\text { (Morphou Bay) }\end{array}$ & 59.6 & 84.8 & +42.3 \\
\hline & Alagadi (Alakati) & 65.7 & 54.1 & -17.7 \\
\hline & East coast & 40.9 & 48.6 & +18.8 \\
\hline & North coast & 37 & 37.9 & +2.4 \\
\hline & Tatlisu (Akanthou) & 30.9 & 36.6 & +18.4 \\
\hline & Chrysochou Bay & 119.8 & 239.1 & +99.6 \\
\hline & West coast & 57.1 & 98.3 & +72.2 \\
\hline \multirow[t]{6}{*}{ Greece } & Zakynthos (Laganas Bay) & 1301.3 & 1084.4 & -16.7 \\
\hline & Southern Kyparissia Bay & 580.7 & 987 & +70.0 \\
\hline & Rethymno, Crete & 387.3 & 275 & -29.0 \\
\hline & Lakonikos Bay & 191.9 & 190 & -1.0 \\
\hline & Bay of Chania, Crete & 114.9 & 74.8 & -34.9 \\
\hline & Messaras Bay, Crete & 53.5 & 46.9 & -12.3 \\
\hline Tunisia & Kuriat Island & 10.2 & 13.5 & +32.4 \\
\hline \multirow[t]{7}{*}{ Turkey } & Dalyan & 165 & 269 & +63.0 \\
\hline & Dalaman & 73 & 92.1 & +26.2 \\
\hline & Fethiye & 124 & 89.4 & -27.9 \\
\hline & Patara & 52.5 & 117.7 & +124.2 \\
\hline & Çıralı & 34 & 66.3 & +95.0 \\
\hline & Belek & 129.7 & 638 & +391.9 \\
\hline & Göksu Delta & 64.6 & 123.8 & +91.6 \\
\hline Total & & 3693.6 & 4667.3 & +26.4 \\
\hline \multicolumn{5}{|c|}{ Chelonia mydas } \\
\hline \multirow[t]{4}{*}{ Cyprus } & Alagadi (Alakati) & 46 & 86.1 & +87.2 \\
\hline & $\begin{array}{c}\text { Akdeniz Beaches } \\
\text { (Morphou Bay) }\end{array}$ & 46 & 48.1 & +4.6 \\
\hline & North coast & 19.3 & 13.1 & -32.1 \\
\hline & West coast & 44 & 70.8 & +60.9 \\
\hline \multirow[t]{3}{*}{ Turkey } & Akyatan & 323 & 319.1 & -1.2 \\
\hline & Kazanlı & 149.2 & 255.8 & +71.4 \\
\hline & Samandağ & 56 & 212.3 & +279.1 \\
\hline Total & & 683.5 & 1005.3 & +47.1 \\
\hline
\end{tabular}

sented by 3 studies of loggerhead turtle bycatch rates. One observed an increase in catch over time in the Gulf of Taranto, Italy (Casale et al. 2012b), while another two in the western Mediterranean showed great variation with a possible decrease (Báez et al. 2014) or increase (Cambiè 2011).

In green turtles, a rough comparison of average nest counts at 7 nesting sites between the same 2 arbitrary periods described above, indicates an overall positive trend (Table 4). In Cyprus, an increasing proportion of neophytes (nesting females captured for the first time and assumed to be in their first year of breeding) was observed (Stokes et al. 2014), suggesting an increasing population. Subsequent work 
suggests that different foraging areas may have contributed unequally (Bradshaw et al. 2017). Monitoring programmes at sea have yet to be established.

\subsection{Gaps and priorities}

In conclusion, our knowledge of the total population abundance in the Mediterranean is limited because of the lack of information about nesting levels in Libya for loggerheads and the paucity of high quality data on demographic parameters (see Section 5). Insights into the relative abundance among foraging areas is currently limited to bycatch and stranding data, while population trends rely on nest counts, which represent a poor index for the current population that is mostly made up of juveniles. Standardised monitoring at sea, through direct sampling or aerial surveys, is a priority for assessing both the relative importance of different areas and population trends.

\section{ANTHROPOGENIC THREATS}

\subsection{Anthropogenic threats in terrestrial habitats}

The main threats occurring at sea turtle nesting sites in different Mediterranean countries are listed in Table S20 in the Supplement and summarised below. It should be noted that, for many of these threats, only generic descriptions have been reported and exact quantification is often lacking. Moreover, reports on these threats are only available from a portion of the nesting sites; therefore, a lack of reports from a specific site does not necessarily imply the absence of that threat. In addition, the lack of exact quantification of threats makes it difficult to compare the severity of their impact among sites and thus assess them at a regional scale.

\subsubsection{Coastal development}

Coastal development is largely the result of recreational/tourist activity and is associated with the presence of hotel resorts and other tourism-related constructions such as restaurants, bars, houses and other businesses typically built along the beach, impacting the original coastline in several ways. Important nesting rookeries in Greece (e.g. Zakynthos and Crete), Turkey (e.g. Dalyan and Belek) and Cyprus are impacted by this tourism-related development (Arianoutsou 1988, Kaska et al. 2010, Margaritoulis \& Panago- poulou 2010, Türkozan \& Kaska 2010, Katselidis et al. 2014), while other rookeries are becoming increasingly vulnerable (e.g. southern Kyparissia Bay, Greece; Margaritoulis \& Panagopoulou 2010) (Table S20).

\subsubsection{Erosion and beach armouring}

Nesting beaches in Greece, Turkey and Cyprus are impacted by erosion due to sand mining, although most activity has ceased over the last decade (e.g. Kasparek et al. 2001, Synolakis et al. 2008, Demetropoulos \& Hadjichristophorou 2010). In order to counteract the impact of erosion, jetties have been constructed along some of these beaches. However, such beach armouring activity is frequently undertaken without appropriate beach and water current dynamics studies and therefore results in accelerating rates of erosion (e.g. Synolakis et al. 2008).

\subsubsection{Recreational activities}

Coastal development is also associated with activities that have an impact on sea turtle nesting activity. Driving on the beach and the use of heavy machinery for beach cleaning purposes are common practices and are responsible for alterations in sand characteristics and the destruction of turtle clutches, with specific reports available at least from some nesting sites in Greece (Arianoutsou 1988, Margaritoulis \& Panagopoulou 2010, Katselidis et al. 2013), Turkey (Türkozan \& Kaska 2010) and Syria (Rees et al. 2010). Beach furniture, beach volley ball courts and artificial lighting on some nesting beaches of Greece, Cyprus and Turkey reduce the habitat available for nesting, prevent females from accessing suitable nesting sites and cause disorientation of hatchlings through light pollution (Ilgaz et al. 2007, Demetropoulos \& Hadjichristophorou 2010, Margaritoulis \& Panagopoulou 2010, Katselidis et al. 2013, Başkale et al. 2016, Dimitriadis et al. 2018). In addition, people on the beach during the night may disrupt nesting activity as sea turtles may abandon their nesting attempts or incubating nests may be destroyed through trampling, with specific reports available from Greece (Margaritoulis \& Panagopoulou 2010).

\subsubsection{Non-human impact}

Negative impacts by animals and plants are included here because, in most cases, non-human pop- 
ulations have increased due to human activities and beachfront vegetation planted by humans. Therefore, in such cases the impact of other species on sea turtles can be considered as an indirect anthropogenic threat.

At many sites around the Mediterranean, predation by mammals has been shown to be a major cause of egg and hatchling mortality (see Table S20). Clutches are most frequently predated by mammals such as red foxes Vulpes vulpes, feral dogs Canis lupus familiaris, golden jackals $C$. aureus and other small mammals, such as badgers Meles meles and martens Martes foina bunites (see Table S20). Predators exhume eggs for consumption and may also eat hatchlings as they emerge from the nest and move to the sea. A predated nest with exposed eggs usually attracts secondary predators, which are not normally able to open a nest and reach the eggs by themselves, such as crabs, rats, martens and various bird species (e.g. Margaritoulis 1988a). Predation levels range from $38 \%$ to as high as $80 \%$ in unprotected nests, although nest screening has reduced that percentage to as low as 5\% (Demetropoulos \& Hadjichristophorou 2010, Fuller et al. 2010, Margaritoulis \& Panagopoulou 2010, Türkozan \& Kaska 2010). Birds such as Caspian gulls Larus cachinnans and various Corvus spp. have been documented predating hatchlings at 2 nesting sites in Greece (Margaritoulis 1985, 1988a). Hatchling predation by ghost crabs Ocypodes cursor has been recorded on Crete (Greece), Cyprus and in Egypt (see Table S20). Nesting females may also be attacked by predators, for instance dogs in Greece (D. Margaritoulis unpubl. data).

Another problem recorded from certain loggerhead nesting beaches is invertebrate infestation of eggs (Broderick \& Hancock 1997, McGowan et al. 2001, Türkozan et al. 2003, Katılmış et al. 2006, Andrews et al. 2016, Aymak et al. 2017). Finally, planting of tamarisk trees Tamarix spp. along East Laganas beach on Zakynthos (Greece) has caused dehydration of several clutches by invading roots (Arianoutsou 1988, Margaritoulis \& Panagopoulou 2010, Margaritoulis et al. 2011a).

\subsubsection{Climate change}

Temperature profiles of monitored nesting beaches in the eastern Mediterranean imply female-biased sex ratios for hatchlings (Casale et al. 2000, Godley et al. 2001a,b, Kaska et al. 2006, Zbinden et al. 2007a, Katselidis et al. 2012, Fuller et al. 2013). In a context of global warming, even more femalebiased hatchling sex ratios may be produced. However, extremely skewed sex ratios resulting from a moderate increase in incubation temperature may not necessarily be negative for the population dynamics; however, a greater threat is represented by a reduced hatching success at higher temperatures (Godley et al. 2001a, Pike 2014, Hays et al. 2017). These concerns are based on the assumption that turtles will maintain the current nesting distribution and phenology, which is uncertain (see Section 7.2.6). A recent model suggests that phenological changes might compensate for the impact of climate changes on hatching success at Zakynthos, Kyparissia and Crete (Greece) (Patel et al. 2016, Almpanidou et al. 2017).

Two additional negative aspects of climate change are the increased storm frequency and sea level rise. Increased storm frequency could increase the risk of inundation of nests, leading to lower reproductive output. Sea level rise will lead to 'coastal squeeze' on many beaches, depending on the beach slope and natural/anthropogenic features potentially preventing the landward shift of beaches (Mazaris et al. 2009c, Katselidis et al. 2014). To evaluate this phenomenon, detailed information on the structure of existing and potential beaches is required.

\subsubsection{Gaps and priorities}

In spite of the great efforts dedicated to conservation activities at nesting sites (see Section 8), published information and assessments of threats are relatively limited. Coastal development represents the main threat to nesting sites because of the associated potentially permanent habitat destruction. The second main threat is represented by animal predation on eggs and hatchlings. This is widespread and reported from most nesting areas, and protecting nests against predators is probably the most common activity undertaken by conservation projects (see Section 8). The human disturbance associated with coastal development may represent a potentially important threat, depending on local regulations and implementation. The general features of all these threats are well understood and effective conservation measures are known and available, although difficult to implement because of contrasting pressures for local development. Climate change remains the most obscure threat in need of specific investigation in terms of habitat reduction and effects on sex ratio and hatchling production. 


\subsection{Anthropogenic threats in marine habitats}

\subsubsection{Interaction with fisheries}

There is a large body of data on turtle bycatch in the Mediterranean, which has recently been reviewed, showing that the level of information available is not equal across countries or sub-regions (Casale 2011). This review estimated over 132000 captures and 44000 deaths in the Mediterranean annually, from all fishing gear combined. The resulting ranking order, from highest to lowest, of different fishing gear for number of captures per year was: pelagic longline, bottom trawl, set net and demersal longline. The ranking order for fatalities was: pelagic longline, set net, bottom trawl and demersal longline. Fishing activity in the eastern basin impacts more heavily on both sea turtle species, as a consequence of patterns of distribution (see Section 4). Other estimates have been published since that review, providing bycatch levels (i.e. number of turtles caught) for specific areas (see Table S21 in the Supplement) or bycatch rates (i.e. turtles caught per unit of effort) (Báez et al. 2013). Of these new studies, only one (Lucchetti et al. 2017) reported results (52000 annual captures in Italy alone) which would indicate a higher bycatch level than previously thought. New information is being gathered from the eastern basin, in areas such as Cyprus or Israel (see Table S21), which still represents understudied areas for turtle bycatch. A list of recent studies on this topic (with or without numerical estimations) is provided in Table S22 in the Supplement.

Due to several gaps and uncertainty in numbers of turtle bycatch, the current figures should be considered as an underestimation. The main problems are (1) unreliable information on total catches of target species, (2) underestimation of turtle captures (Coll et al. 2014, Piroddi et al. 2015), (3) underestimation of artisanal fleet sizes, (4) poor data reporting in artisanal fleets (Panagopoulou 2015, Panagopoulou et al. 2017) and (5) rapid changes in gear, affecting bycatch (Piovano \& Swimmer 2017).

Small-scale fleets (SSF), polyvalent vessels up to $12 \mathrm{~m}$ length overall, are the dominant fishery segment accounting for $80 \%$ of the total fishing fleet in the Mediterranean and Black Sea (FAO 2016) (for a detailed review and discussion on this fishery see Echwikhi et al. 2012, and also Snape et al. 2013). Sea turtles are at high risk from SSF and this fishery may be responsible for most of the fishing-induced mortality in the Mediterranean (Carreras et al. 2004, Echwikhi et al. 2010, 2012, Casale 2011, Coelho et al. 2013). Although driftnets targeting tuna species were banned by the ICCAT (International Commission for the Conservation of Atlantic Tunas) and GFCM (General Fisheries Commission for the Mediterranean), in 2003 and 2005, respectively, illegal fleets still use driftnets in countries such as Albania, Italy, Algeria, Tunisia and Turkey (Environmental Justice Foundation 2007, Bănaru et al. 2010). However, the number of turtles caught by this fishery is unknown.

Bottom trawlers may cause death by drowning, and mitigation measures include, among others, modification of the gear (turtle excluder device or TED) to allow any captured turtles to escape from the net (FAO 2009, Bitón Porsmoguer et al. 2011, Lucchetti et al. 2016), reducing towing time, and keeping the comatose (i.e. semi-drowned) turtles onboard until they recover (Gerosa \& Aureggi 2001, FAO 2009, Domènech et al. 2015). However, decompression sickness in bycaught turtles may represent an additional and, until recently, overlooked problem (García-Párraga et al. 2014, Fahlman et al. 2017). Pelagic longlines mostly cause death after release as a result of internal damage caused by the line and secondarily by the hook (Casale et al. 2008b, Parga 2012, Álvarez de Quevedo et al. 2013). Mitigation measures include, among others, the modification of the gear by using larger hooks (e.g. the so-called 'circle hooks') (Piovano et al. 2012, Gilman \& Huang 2017), which reduce the catch rate, and by removing the gear (especially the line) from the turtle before releasing it (Gerosa \& Aureggi 2001, FAO 2009). Set nets cause death by drowning, with very high mortality rates due to the long time the nets are left in the water (Echwikhi et al. 2012) and the only mitigation measure available at present consists of illuminating the net so that turtles can see and avoid it (Ortiz et al. 2016, Virgili et al. 2018).

Incidental catch of loggerhead turtles by traditional fish aggregating devices (FADs) have been reported from the Tyrrhenian Sea (Blasi et al. 2016). These captures may result in a degree of mortality caused by entanglement.

Given the high fishing effort and the likelihood of losing part of a fishing gear, incidental capture of turtles by abandoned fishing gear (so-called 'ghost gear') is probably a problem worldwide, although only a few reports are available (Duncan et al. 2017). These include cases involving Mediterranean loggerhead turtles (Casale et al. 2010a, Blasi \& Mattei 2017), but the potential impact of ghost gear is still unknown.

In addition to the mortality induced by capture, turtles may be subject to intentional killing by fishermen either for consumption (see Section 7.2.2) or as a result of hostility due to presumed damage of fishing 
gear or competition for fish. The latter has been reported from several Mediterranean countries (Broderick \& Godley 1996, Casale et al. 2010b, Margaritoulis \& Panagopoulou 2010).

\subsubsection{Human exploitation}

Historically severe exploitation of turtles occurred in the first half of the 20th century, with mainly green but also loggerhead turtles being collected in the waters off eastern Turkey, Lebanon, Israel and Palestine and sold to markets in the UK and Egypt (Hornell 1935, Sella 1982). These activities have now for the most part ceased due to the enforcement of regulations, and national and international legislation, and it appears that only some areas, such as Egypt, such as continue to clandestinely market a significant amount of turtle meat (Nada \& Casale 2011). However, limited levels of consumption in other areas cannot be excluded.

\subsubsection{Marine debris and pollution}

Sea turtles can ingest or become entangled in anthropogenic debris. Entanglement has been reported as an important stranding cause in the Mediterranean, in contrast to ingestion (Tomás et al. 2008, Casale et al. 2010a). Studies on marine debris ingestion by sea turtles in the Mediterranean have been reviewed by Casale et al. (2016). Debris in gut contents or faeces of sea turtles has been reported in the western, south-central, Adriatic and eastern basins (see Table S23 in the Supplement). Occurrence of marine debris varied among studies, with the highest occurrence $(80 \%)$ reported from turtles caught by pelagic longlines in the central Mediterranean (Casale et al. 2016). When reported, most of the turtles with debris have small amounts and there are almost no lethal cases (Casale et al. 2016). Studies on debris ingestion are subject to several potential biases and caveats, especially if based on strandings, and careful sampling is needed to extract valid conclusions (Tomás et al. 2008, Casale et al. 2016). Recent studies on risk assessment reveal the high exposure of the loggerhead sea turtle to marine debris and the use of this species as an indicator for monitoring the impact of marine litter in marine biota has been suggested by some authors (Darmon et al. 2017, Matiddi et al. 2017) but criticised by others for methodological reasons (Casale et al. 2016). The effects of microplastics have yet to be assessed (Nelms et al. 2016a).
Chemical pollutants also represent a potential threat for sea turtles, considering the semi-enclosed nature of the Mediterranean and that several large rivers outflow into different regions. The Rhône and Ebro rivers, located in south-eastern France and northeastern Spain, respectively, are both known to have very high concentrations of contaminants (Nolting \& Helder 1991). The marine environment close to the Po Delta and the Goro Bay (north Adriatic) has a high heavy metal content (references in Franzellitti et al. 2004).

The presence of heavy metals in sea turtles has been studied in different parts of the Mediterranean Sea (see Table S24 in the Supplement). Most of the concentration values were below toxic levels, except in the northern Adriatic (Franzellitti et al. 2004) and southern Turkey (Kaska et al. 2004). No explanation was provided for the high concentration levels in Turkey (Kaska et al. 2004), although lower levels were reported from a nearby area, Cyprus (Godley et al. 1999). Mediterranean loggerhead turtles have higher concentrations of both organic contaminants (polychlorinated biphenyls [PCBs], organochlorines and polycyclic aromatic hydrocarbons [PAHs]) and metals (cadmium, copper, lead, mercury and zinc) than turtles frequenting the waters of the Canary Islands, in the Atlantic (Bucchia et al. 2015).

Most of the studies on pollutants in Mediterranean sea turtles have focused specifically on the presence of persistent organic pollutants (POPs) such as PCBs, PAHs and DDT metabolites (McKenzie et al. 1999, Storelli et al. 2007, D'Ilio et al. 2011, Lazar et al. 2011b, Bucchia et al. 2015). However, many other toxic byproducts from human activities can reach the sea. To date, few studies have performed global chemical screening and risk assessments. A recent exploratory screening detected a total of 39 different pesticides in juvenile loggerheads from the western Mediterranean, most of them previously undetected in this species and many of them of non-approved use in the EU (Novillo et al. 2017). Higher organochlorine contaminant (OC) concentrations were observed in the carnivorous loggerhead turtle than in the herbivorous green turtle, probably due to diet-related bioaccumulation, and in green turtles, lipid contaminant burdens decreased with size, probably related to ontogenetic changes in diet (McKenzie et al. 1999). Although loggerhead turtles may be more appropriate bioindicators of pollutants than other marine species due to biomagnification at higher trophic levels (Storelli \& Zizzo 2014), variability in their diet makes it difficult to elucidate consistent trends (Storelli et al. 2005). 
Petrochemical industrial activities are increasing in the Mediterranean and exploratory seismic activity has the potential to impact sea turtles, especially on the coastal shelf (Nelms et al. 2016b). As evidenced in the Gulf of Mexico in recent years, cataclysmic oil spills can occur with serious impacts on turtles and other wildlife (Lauritsen et al. 2017, McDonald et al. 2017, Wallace et al. 2017).

\subsubsection{Recreational activities}

Water sports, an activity interlinked with high tourist activity, can lead to boats colliding with turtles, especially close to nesting areas where turtle density is high. There are scant references on the exact impact of recreational boats, but in other regions, it has been found that turtles are unable to avoid being struck by a vessel at speeds higher than $4 \mathrm{~km} \mathrm{~h}^{-1}$ (Hazel \& Gyuris 2006, Hazel et al. 2007). Deaths due to speedboat collisions have been documented in Greece (Zakynthos and Rethymno) (Arianoutsou 1988, Margaritoulis \& Panagopoulou 2010, Schofield et al. 2013b) and in Turkey (Kaska et al. 2011). At Zakynthos (Greece), turtle-watching has been advocated in place of water sports but has raised concerns about potential negative impacts on turtles. A recent study found that the disturbance level for individual turtles intensifies during the summer as the demand to observe them increases, although the small area used for this activity likely results in a relatively low impact at the population level (Schofield et al. 2015).

\subsubsection{Non-human predation}

Great white sharks Carcharodon carcharias regularly consume loggerhead turtles in the Mediterranean (Fergusson et al. 2000); however, this can be considered as natural predation. Mediterranean monk seals Monachus monachus have been documented predating on adult loggerheads on Zakynthos (Greece) during the reproductive season (May to October) (Margaritoulis \& Touliatou 2011) and green turtles have also been found in the stomach contents of stranded monk seals in Turkey (Tonay et al. 2016). Such predation events may be related to overfishing of cephalopods such as octopuses, one of the principal sources of food for monk seals (Pierce et al. 2011), which may have caused them to turn to alternative sources of prey.

\subsubsection{Climate change}

Predictions for future rises in global temperature raise concerns for sea turtle populations in the Mediterranean (Witt et al. 2010b). Some studies have shown that changes in environmental conditions at the breeding sites significantly influence the timing, quantity and quality of loggerhead nesting in the region (e.g. Mazaris et al. 2008a, 2009a, 2013, Katselidis et al. 2014, Patel et al. 2016). However, another study using climatic suitability thresholds, suggests that most populations in the Mediterranean will remain viable (Almpanidou et al. 2016).

The loggerhead nesting season has been starting earlier in Greece and seasons starting as many as 74 d earlier are predicted by 2100 (Mazaris et al. 2013, Patel et al. 2016). However, these studies used the first nest of the season, which might not be representative of the population, and more comprehensive analyses are desirable. Although sea turtle phenology may shift to adapt to the increasing temperatures, climatic changes in foraging and overwintering habitats will probably negatively affect loggerhead turtle populations nesting in the eastern Mediterranean Basin (Patel et al. 2016). Maffucci et al. (2016) have suggested that increased environmental temperatures, especially during spring when turtles mate and prepare for reproduction, may have already caused an increase in nesting activity in the western Mediterranean Basin. However, the same study also showed that current oceanic conditions in this area do not yet favour hatchling survival.

\subsubsection{Gaps and priorities}

A range of anthropogenic threats at sea are documented or suspected in the Mediterranean. Although the observation of interactions or effects of specific human activities or products may be common, such observations may be biased by our limited monitoring methods. Causes of mortality among stranded individuals represent the best available source of information about the relative importance of different threats, and indicate that interaction with fisheries is the most important threat in the basin (Tomás et al. 2008, Casale et al. 2010a). Different annual survival probabilities among areas have also been interpreted as evidence of the impact of fisheries (Casale et al. 2015). However, such comparisons are still too few and geographically limited. Different approaches covering more areas and threats would be desirable. 
Although bycatch is the best-studied threat in the Mediterranean so far, the available information is still biased in terms of areas and fishing gear, making a robust quantification of captures and mortality uncertain. Some mitigating measures are available, but the level of their implementation is probably still too low to exert a significant positive effect at the population level (see Section 8.3).

Human exploitation is greatly reduced in comparison to the past. However, being now illegal, it may be less evident and underestimated. Whilst a relatively high mortality is induced by entanglement in anthropogenic debris, with a potential impact at the population level, there is no evidence of high mortality induced by debris ingestion. Current knowledge with respect to chemical pollutants and microplastics is not adequate to inform on effects at individual or population levels. Given the widespread and different sources of such pollutions, no simple mitigating measures are available at present.

Recreational activities at sea can potentially harm individual turtles and might even represent important threats at population level, especially if performed in breeding areas. However, current reports are limited to a few breeding sites, and the effects of these activities need to be better quantified.

Predation by animals as a possible indirect consequence of human action is limited to monk seals in Greece and may represent a serious threat for a specific nesting population. However, there is currently no evidence of this or similar cases in other areas.

A better knowledge of the dynamics and plasticity of sea turtle phenology will be fundamental to understand the potential effects of climate change on sea turtle nesting. The potential effects on other aspects such as trophic resources and growth also need to be addressed.

\section{CONSERVATION STATUS}

After 2 to 3 decades of protection and other active conservation measures, positive trends in nest counts are being observed at several nesting sites (see Section 6 , Table 4), which may be interpreted as a sign of recovery from past depletion, as suggested for several nesting sea turtle populations worldwide (Mazaris et al. 2017). As a result of this and other criteria, the Mediterranean loggerhead population was recently listed as Least Concern in the IUCN Red List of Threatened Species (Casale 2015). There is no regional assessment of the green turtle Mediterranean population as yet. As described below with specific examples, the current conservation status is a direct result of continuous, intense and varied conservation activities and cannot be assumed to be permanent. In other words, the continuation of these activities is necessary and their hypothetical cessation would likely cause a rapid degradation of the situation and of the conservation status. For these reasons, the Mediterranean populations of the 2 species should be considered as 'conservation dependent', as stressed in the recent IUCN Red List assessment for the loggerhead turtle (Casale 2015).

\subsection{International and national legislation}

Several international conventions and their adoption by Mediterranean countries with national laws (see Table S25 in the Supplement) represented a fundamental step for the conservation of sea turtles in the region. One of the most important effects was that direct exploitation has been stopped or greatly reduced (limited to illegal activities) (see Section 7).

\subsection{Conservation measures in terrestrial habitats}

Activities undertaken by governmental and nongovernmental organisations focusing on specific nesting sites have represented most of the conservation effort produced in the region to date. The main areas for nesting site conservation are in Cyprus, Greece and Turkey, which host the majority of clutches laid.

On the west coast of Cyprus, monitoring/protection of turtle nesting started in 1978. At that time, about 70 to $80 \%$ of the nests on most beaches were predated by foxes (Demetropoulos \& Hadjichristophorou 2010). The Lara/Toxeftra Turtle Reserve, which includes the 5 main green turtle nesting beaches, covers $10 \mathrm{~km}$ of coastline and includes a sea area up to the $20 \mathrm{~m}$ isobath. It has been legally protected since 1989 by the Fisheries Regulations (Fisheries Law CAP 135 and Regulations 273/90), with penalties for infringements, including fines and imprisonment. Lara/Toxeftra and the Polis/Limni/Gialia (Chrysochou Bay) area, which covers about $10 \mathrm{~km}$ of coastline and sea, are EU Natura 2000 sites and they contain about $80 \%$ of all the loggerhead nests and over $90 \%$ of all green turtle nests. Nests are caged in both areas and this has reduced predation to less than 10\% (A. Demetropoulos $\&$ M. Hadjichristophorou unpubl. data). This is deemed to be the main reason for the recent increases in loggerhead and green turtle nesting. 
On the northern coast of Cyprus, the nesting population of green and loggerhead turtles has been monitored since 1992. A major part of this project involves the protection of clutches from dogs and foxes, which has reduced predation at some beaches to zero. This is likely to be one of the reasons for the recent positive nesting trends seen for both species. Beach development also represents a significant threat and specific conservation measures include the designation of 5 Special Environmental Protected Areas (SEPAs) containing turtle nesting beaches, also identified as potential Natura 2000 sites of the $\mathrm{EU}$, and continued education and awareness raising.

In Greece, the 2 areas hosting the largest nesting aggregations in the Mediterranean, Laganas Bay
(Zakynthos) and southern Kyparissia Bay, have been systematically monitored since 1984 by ARCHELON (Margaritoulis \& Rees 2001, Margaritoulis 2005). In 1994, the private land behind the main nesting beach in Zakynthos was acquired by WWFGreece, creating the core area for the future National Marine Park of Zakynthos established in 1999 thanks to severe pressure from the EU, the Bern Convention and international organisations (Dimopoulos 2001). In southern Kyparissia Bay, a massive nestprotection programme started in 1992 and reduced the predation rate by foxes from about 50 to $13 \%$, which is a possible cause of the considerable increase in the number of nests and in the proportion of neophyte turtles observed in the last few years (Mar-

Table 5. Research priorities for sea turtles in the Mediterranean. CC: Caretta caretta; ALL: Caretta caretta and Chelonia mydas; RMU: regional management unit. The sections of the text in which the topics are discussed are indicated. Only the top 10 priorities are shown. For the complete list see Table S26 in the Supplement

\begin{tabular}{|c|c|c|c|c|}
\hline Rank & Section & Section topic & Species & Priority \\
\hline 1 & $\begin{array}{l}4.2,4.3 \\
4.4, \& 6\end{array}$ & $\begin{array}{l}\text { Foraging areas and migratory corridors } \\
\text { Population abundance and trends }\end{array}$ & ALL & $\begin{array}{l}\text { Set up long-term in-water monitoring programmes in } \\
\text { key foraging areas for assessing sea turtle abundance } \\
\text { and trends }\end{array}$ \\
\hline 2 & $3 \& 6$ & $\begin{array}{l}\text { Distribution of nesting areas } \\
\text { Population abundance and trends }\end{array}$ & $\mathrm{CC}$ & Assess distribution and level of nesting activity in Libya \\
\hline
\end{tabular}

\begin{tabular}{llll}
\hline $3 \quad$ Anthropogenic threats & ALL & $\begin{array}{l}\text { Quantify bycatch (especially in small-scale fisheries) } \\
\text { rates and intentional killings in associated mortality } \\
\text { key foraging areas and migratory pathways }\end{array}$
\end{tabular}

\begin{tabular}{|c|c|c|c|c|}
\hline 4 & 7 & Anthropogenic threats & ALL & $\begin{array}{l}\text { Understand how climate change might impact sex } \\
\text { ratios, geographical range and phenology }\end{array}$ \\
\hline 5 & $5 \& 6$ & $\begin{array}{l}\text { Population structure and dynamics } \\
\text { Population abundance and trends }\end{array}$ & ALL & Estimate/improve estimates of demographic parameters \\
\hline
\end{tabular}

\begin{tabular}{lllll}
\hline 6 & 6 & Population abundance and trends & ALL & Improve population abundance estimates \\
\hline 7 & 4 & Foraging areas and migratory corridors & ALL & $\begin{array}{l}\text { Assess the movement patterns of adults from key } \\
\text { rookeries }\end{array}$ \\
\hline 8 & 4 & Foraging areas and migratory corridors & ALL & $\begin{array}{l}\text { Identify development habitats of post-hatchling and } \\
\text { small turtles, and dispersal and settlement patterns. }\end{array}$
\end{tabular}

94 Foraging areas and migratory corridors ALL Assess the movement patterns of juveniles

\begin{tabular}{llll}
\hline 10 & Threats & ALL & Develop and test new bycatch reduction methods
\end{tabular}


garitoulis et al. 2011b, D. Margaritoulis unpubl. data). Gradual coastal degradation and recent developmental plans in southern Kyparissia Bay (a Natura 2000 site) resulted in the EU taking Greece to the European Court of Justice. As a result, a protective Presidential Decree was issued (now at its final consultation stage). In the decade from 1985 to 1995, monitoring and nest protection programmes also started in other nesting areas (Lakonikos Bay, Rethymno, Chania, Messaras Bay, Koroni). Most nesting areas are today included, in total or in part, in the EU's Natura 2000 network.

In Turkey, regular sea turtle nest-monitoring programmes and conservation activities started in 1988, with a total of 21 identified nesting sites so far
(Türkozan \& Kaska 2010). Of these, only 3 (Dalyan, Patara and Akyatan) are undeveloped, whilst the other 18 are either fully developed or under development. The main problems on these beaches are tourism development and natural predation (Canbolat 2004, Türkozan \& Kaska 2010). Conservation and monitoring programmes are supported by the Turkish Ministry of Forestry and Water at 12 sites, while the remaining 9 sites are monitored irregularly. Additionally, WWF-Turkey and some local NGOs support sea turtle conservation and monitoring programmes. The major activities of these projects are caging and relocation of nests, public awareness and beach furniture control (e.g. sunbeds and umbrellas). Furthermore, hatchlings are guided

Table 5 (continued)

Justification/description

Although valuable and necessary, nest counts represent a poor index of population abundance and trends because of the high uncertainty of the parameters needed to estimate population abundance from nest counts. Quantitative estimates derived from distance sampling should be generated for key foraging sites across the Mediterranean.

In contrast to other areas, the level of nesting activity along the Libyan coast is still unknown, and even the existence of major nesting sites cannot be excluded, as $66 \%$ of the sandy coast, corresponding to ca. $600 \mathrm{~km}$, has never been surveyed (Hamza 2010 ). The lack of information on nest distribution prevents any site-specific protection plan, while the unknown nesting activity level prevents the quantification of the abundance of the Mediterranean RMU, needed for conservation status assessments and for modelling population dynamics.

Bycatch in fishing gear, including small-scale fisheries, is the major threat for Mediterranean sea turtle populations. Quantifying the mortality and catch rate by gear and year is of paramount importance to understand the real effects of fisheries and the validity of the conservation measures already implemented, and to enable the proposal of new bycatch reduction approaches and tools.

The current poor knowledge of the possible effects of climate change on several life-history parameters of turtles impedes understanding of the potential gravity of this threat in comparison to others.

Demographic data are of crucial importance for population modelling to guide sound conservation of sea turtles. Population vital rates are under the influence of both environment and intrinsic population factors, and may differ among populations using different areas. Although some demographic information has recently become available for loggerheads, environmental variance and different threat levels across the Mediterranean Basin require further site-specific demographic studies, especially for green turtles, for which such data are still entirely lacking. Priorities: age at maturity, annual survival probability for different age classes.

Information on the population abundance by age is still lacking.

Movement patterns and hot-spot areas are poorly known for adults (females and males) breeding in most rookeries. Priorities: the top 5 rookeries in Turkey, Kyparissia Bay (Greece) and Libya (loggerheads); Akyatan and Kazanlı (Turkey), Latakia (Syria) and Ronnas Bay (Cyprus) (green turtles); e.g. through satellite tracking.

Knowledge of how ocean dynamics affect the distribution of post-hatchlings/small turtles, the pressures on turtles in these nursery areas and the dispersal and settlement behavioural patterns will help to assess ecological niches and climate change effects. Tracking of small turtles is becoming more easily possible thanks to the recent miniaturisation of telemetry devices.

Juvenile movement patterns and hot-spot areas are poorly known in the Aegean Sea, south of Turkey, Levantine Sea, Libyan Sea and southern Adriatic (both species) and in the Ligurian Sea, Tyrrhenian Sea, Ionian Sea and Sicilian Strait (loggerheads). This should be assessed using telemetry studies at each location.

There is a general paucity of bycatch mitigating measures and the existing ones may not be applicable in all cases. 
to the sea in order to prevent disorientation on developed beaches. Caging has greatly reduced predation, for example in Dalyan, where the predation rate dropped from over $50 \%$ (Erk'akan 1993) in 1989 to $26.9 \%$ in 2004-2005 (Türkozan \& Yilmaz 2008).

Judging from the situations described above, the current conservation status of sea turtles cannot be considered as permanent, and protection of key nesting sites throughout the Mediterranean remains a priority requiring continuous attention and effort. This is more obvious for activities like individual nest protection (often by NGOs) from various threats (e.g. predation, inundation, trampling, bright lights), but is also true for the legal protection status of key areas, continuously challenged by the pressures for coastal development driven by economic interests. The recent increase in nest numbers at some sites may induce decision makers to derive simplistic conclusions and to withdraw funding and protection measures that took years to put in place. This requires particular attention and promotion of science-based conservation policy, in which long-term monitoring projects play a key role. If the ongoing conservation schemes are interrupted, the existing conservation status will be compromised, with the risk of a rapid and permanent degradation, resulting in a swift reduction in Mediterranean sea turtle hatchling production.

\subsection{Conservation measures in marine habitats}

As described in Section 7, the main anthropogenic threat at sea is considered to be bycatch in fishing gear. However, in contrast to nesting sites, the intensity of conservation initiatives aimed at mitigating this threat is still very low. This is in part due to the intrinsic difficulty in tackling fisheries, technically, economically and politically. A range of regulations and resolutions related to turtle bycatch and mitigation measures adopted by the ICCAT and GFCM are currently implemented by the legislation of a number of Mediterranean countries. Enforcement of and compliance with mitigation measures is a complex issue in fisheries needing different approaches. After reviewing different fisheries that implemented some measures to reduce the bycatch of non-target and threatened species, Cox et al. (2007) concluded that 'compliance, essential for bycatch reduction, depends heavily on enforcement and/or incentives'. Areas closed to fishing adjacent to nesting beaches and over foraging grounds have been used in Cyprus to reduce turtle bycatch (Demetropoulos \& Hadjichristophorou 2009). Technical modifications that can reduce turtle bycatch have been developed in other areas for some fishing gear, e.g. large circle hooks for pelagic longlines, TEDs for trawlers, and lights for set nets (FAO 2009, Ortiz et al. 2016, Gilman \& Huang 2017). However, so far, such technical changes have

Table 6. Conservation priorities for sea turtles in the Mediterranean. Research should be associated with all measures in order to assess their effectiveness. CC: Caretta caretta; ALL: Caretta caretta and Chelonia mydas; TED: turtle excluder device; MPA: marine protected area. The sections of the text in which the topics are discussed are indicated

\begin{tabular}{|lclll}
\hline Rank & Section & Section topic & Species & Priority \\
\hline 1 & 7 & $\begin{array}{l}\text { Anthropogenic } \\
\text { threats }\end{array}$ & ALL & Year-round protection of key feeding and wintering grounds \\
\hline 2 & 7 & $\begin{array}{l}\text { Anthropogenic } \\
\text { threats }\end{array}$ & ALL & $\begin{array}{l}\text { Continue current conservation methods at nesting areas } \\
\text { (in situ protection, relocations, light management, etc.) }\end{array}$ \\
\hline 3 & $\begin{array}{l}\text { Anthropogenic } \\
\text { threats }\end{array}$ & ALL & Educate fishermen on on-board sea turtle handling best practices \\
\hline 4 & $\begin{array}{l}\text { Anthropogenic } \\
\text { threats }\end{array}$ & ALL & Seasonal protection of main migratory corridors \\
\hline 5 & $\begin{array}{l}\text { Anthropogenic } \\
\text { threats }\end{array}$ & ALL & Implement TED in bottom trawlers \\
\hline 6 & $\begin{array}{l}\text { Anthropogenic } \\
\text { threats }\end{array}$ & CC & Trans-boundary large MPA in the Adriatic \\
\hline 7 & $\begin{array}{l}\text { Anthropogenic } \\
\text { threats }\end{array}$ & ALL & Implement LED lights in set nets \\
\hline
\end{tabular}


not been included as mandatory in the national legislation of any Mediterranean country. They have only been tested (Bitón Porsmoguer et al. 2011, Cambiè et al. 2012, Piovano et al. 2012, Báez et al. 2013, Lucchetti et al. 2016) and, in some cases, also promoted under a volunteer approach among individual fishers in certain specific and short-term conservation projects (in Croatia, Cyprus, Greece, Italy, Slovenia and Spain), including a few funded by the LIFE instrument of the European Union (e.g. LIFE12 NAT/IT/ 000937, LIFE15-NAT/HR/000997). A different mitigation measure has been more widely implemented, again in specific projects and organisations at local level (in Croatia, Greece [LIFE2002NAT/GR/8500], Italy, Slovenia and Spain), and consists of informing fishers of the best onboard practices to reduce postrelease mortality (Gerosa \& Aureggi 2001), i.e. the mortality occurring after the turtle is released in apparently good condition. Given the bycatch level and associated mortality (see Section 7), all these efforts, although valuable, are probably still far from achieving significant mitigation of this threat at regional and population levels.

\section{CONCLUSIONS AND RECOMMENDATIONS}

The present review describes the status of current scientific knowledge regarding sea turtles in the
Mediterranean region. This knowledge has radically improved over recent decades. However, knowledge levels are not homogeneous, with more research efforts allocated to loggerhead turtles, some geographic areas or topics, and with results that are not always comparable. Significant gaps exist for the most fundamental topics, such as the distribution of major nesting sites and total number of clutches laid annually in the Mediterranean, to more specific topics like age at maturity, survival rates, at sea abundance and mortality, and behaviour.

From the gaps identified in each section of this review, a list of research and conservation priorities was derived, then discussed and rearranged by the authors into 2 final lists. These lists were ranked in order of priority by each author, in terms of potential impact for conservation, and the final ranking was derived from the average score of each item. The 10 top research priorities (Table 5), out of a total of 24 (see Table S26 in the Supplement), and 7 conservation priorities (Table 6) resulted from this exercise. Research priorities nos. 2, 4 and 10 are technically challenging, i.e. they require the development of adequate methods or approaches, and no. 2 also presents additional problems due to the current political situation in Libya. Conservation priorities nos. 1, 4 and 6 aim to protect turtles from bycatch in large marine areas, and therefore are politically challenging, as are conservation priorities nos. 5 and 7 , which aim to

Table 6 (continued)

Justification/description

Protection from fishing in highly frequented areas. See Section 4 for key foraging grounds, e.g. Libya/Tunisia border, Gulfs of Sirte and Bomba (Libya), Gulfs of Salum and Arab Bay (Egypt), Tripoli (Lebanon), Tunisian Plateau, northern Adriatic. This measure requires regulations at national level or international agreements and therefore is ambitious and challenging.

All the current conservation activities at nesting sites increase hatchling production. Given that they are already ongoing, such measures are feasible and only require maintaining the current level of conservation efforts.

This measure aims to reduces post-release mortality. It has already been implemented in several areas and it can be considered feasible. It needs to be expanded into more areas.

Protection from fishing in highly frequented areas. See Section 4 for key migratory corridors. This measure requires regulations at national level or international agreements and therefore is ambitious and challenging.

Flexible TED reduces bycatch without losses of Mediterranean target species (Lucchetti et al. 2016). Its implementation is technically feasible, but requires commitment by decision makers and investment.

Protection from fishing (in particular trawlers) in a highly frequented areas in the Adriatic (Bastari et al. 2016). This measure requires international agreements and therefore is ambitious and challenging.

Illuminating nets decreases turtle bycatch (Ortiz et al. 2016). Its implementation is technically feasible but the large size of this fishing fleet requires significant commitment by decision makers, investment and enforcement. 
reduce turtle bycatch through the large-scale implementation of the available technical modifications of fishing gear. The other 7 research priorities and 2 conservation priorities require significant investments in terms of effort and resources but are technically feasible with the available methods or approaches.

Seven of the top 10 research priorities (nos. 3 to 5 and 7 to 10; Table 5) fall within the wider area of 6 global metaquestions for research on sea turtles identified by an international group of experts (Hamann et al. 2010, their metaquestions $2.1,2.2,2.3,3.2,4.1,4.2$, Rees et al. 2016). However, the latter represent the most promising research questions for a long-term global vision, while the present review highlights very specific regional needs like estimation of abundance and trends.

First of all, however, there is a general and urgent need to make a large quantity of unpublished data available through reputable scientific publications. This is a general problem for sea turtles (e.g. Mazaris et al. 2017), with the need to explore possible solutions (e.g. Schofield 2017). For instance, a great deal of nesting activity data is almost a decade old or even older in some cases and data are incomplete for many beaches, with missing years and varying amounts of coverage both spatially and temporally. Another example is the satellite-tracking data from a number of different projects which are still unpublished. While these data as a whole can allow a significant advance in our understanding of sea turtle aspects at a regional level, the importance of single sets of data is not perceived by the individual projects. Stronger networking and cooperation in the Mediterranean is desirable in order to improve knowledge and conservation efforts with respect to sea turtles in the Mediterranean Sea.

Acknowledgements. A.C.B. and B.J.G. acknowledge all those who have supported, funded and volunteered for the Marine Turtle Conservation Project and the Society for the Protection of Turtles. J.A.C. acknowledges the collaboration of Spanish fleets and fishermen working with surface longline targeting tuna and tuna-like species in the western Mediterranean Sea and the facilities and support provided to the IEO researchers and to all the onboard observers working with IEO; he also recognises the work and new ideas proposed by the team involved in Malaga Centre in fisheriesturtles interactions over more than $20 \mathrm{yr}$. C.C. is supported by the project CTM2013-48163 of the Spanish Ministry of Economy and Competitivity. The Cyprus Wildlife Society (CWS) acknowledges the financial support of the Department of Fisheries and Marine Research of the Government to the CWS for the implementation of the Turtle Conservation Project in the period 2010-2016 and for all its assistance to the Society in previous years. W.J.F. thanks the Society for the Protection of Turtles and the Marine Turtle Conservation
Project volunteers based in northern Cyprus for all their efforts over the past $25 \mathrm{yr}$. S.H. is thankful for the support of the Stazione Zoologica Anton Dohrn and Regione Campania (INFEA - U.O.D. 07), for the hard work of dedicated colleagues and all collaborating partners. D.M. and A.P. thank all ARCHELON field leaders, assistants and volunteers for the many hours of hard work and their dedication to the conservation of sea turtles. J.T. is supported by project Prometeo II (2015-018) of the Generalitat Valenciana and projects MEDSEALITTER-INTERREG and INDICIT of the European Union. We also thank 3 anonymous reviewers for their helpful comments on a first version of the manuscript.

\section{LITERATURE CITED}

Almpanidou V, Schofield G, Kallimanis AS, Türkozan O, Hays GC, Mazaris AD (2016) Using climatic suitability thresholds to identify past, present and future population viability. Ecol Indic 71:551-556

Almpanidou V, Katragkou E, Mazaris AD (2017) The efficiency of phenological shifts as an adaptive response against climate change: a case study of loggerhead sea turtles (Caretta caretta) in the Mediterranean. Mitig Adapt Strategies Glob Change, https://doi.org/10.1007/ s11027-017-9777-5

Álvarez de Quevedo I, Cardona L, De Haro A, Pubill E, Aguilar A (2010) Sources of bycatch of loggerhead sea turtles in the western Mediterranean other than drifting longlines. ICES J Mar Sci 67:677-685

* Álvarez de Quevedo I, San Félix M, Cardona L (2013) Mortality rates in by-caught loggerhead turtle Caretta caretta in the Mediterranean Sea and implications for the Atlantic populations. Mar Ecol Prog Ser 489:225-234

Andrews AJ, Smith AC, Rees AF, Margaritoulis D (2016) The effect of invertebrate infestation and its correlation with loggerhead sea turtle (Caretta caretta) nest success in Laganas Bay, Zakynthos, Greece. Mar Turtle Newsl 151:9-15

Argano R, Basso R, Cocco M, Gerosa G (1992) New data on loggerhead (Caretta caretta) movements within the Mediterranean. Boll Musei Ist Biol Univ Genova 56-57:137-163

Arianoutsou M (1988) Assessing the impacts of human activities on nesting of loggerhead sea-turtles (Caretta Caretta L.) on Zákynthos island, western Greece. Environ Conserv 15:327-334

Aymak C, Ergene S, Katilmiş Y, Uçar AH (2017) Invertebrate infestation in green turtle (Chelonia mydas (Linnaeus, 1758)) and loggerhead turtle (Caretta caretta (Linnaeus, 1758)) nests on Alata beach, Mersin, Turkey. Turk J Zool 41:753-761

*Báez JC, Macías D, Camiñas JA, Ortiz de Urbina JM, García-Barcelona S, Bellido JJ, Real R (2013) By-catch frequency and size differentiation in loggerhead turtles as a function of surface longline gear type in the western Mediterranean Sea. J Mar Biol Assoc UK 93:1423-1427

*Báez JC, Macías D, García-Barcelona S, Real R (2014) Interannual differences for sea turtles bycatch in Spanish longliners from western Mediterranean Sea. Sci World J 2014:861396

Bagda E, Bardakci F, Türkozan O (2012) Lower genetic structuring in mitochondrial DNA than nuclear DNA among the nesting colonies of green turtles (Chelonia mydas) in the Mediterranean. Biochem Syst Ecol 43: 192-199 
Bănaru D, Dekeyser I, Imbert G, Laubier L (2010) Non-target and released alive by-catches distributions observed during French driftnet fishery in the Northwestern Mediterranean Sea (2000-2003 database). J Oceanogr Res Data 3:33-45

Baran I, Türkozan O (1996) Nesting activity of the loggerhead turtle, Caretta caretta, on Fethiye Beach, Turkey, in 1994. Chelonian Conserv Biol 2:93-96

Başkale E, Katılmış Y, Azmaz M, Sözbilen D and others (2016) Monitoring and conservation of loggerhead turtle's nests on Fethiye Beaches, Turkey. Biharean Biol 10: 20-23

Bastari A, Micheli F, Ferretti F, Pusceddu A, Cerrano C (2016) Large marine protected areas (LMPAs) in the Mediterranean Sea: the opportunity of the Adriatic Sea. Mar Policy 68:165-177

Bentivegna F (2002) Intra-Mediterranean migrations of loggerhead sea turtles (Caretta caretta) monitored by satellite telemetry. Mar Biol 141:795-800

Bentivegna F, Valentino F, Falco P, Zambianchi E, Hochscheid S (2007) The relationship between loggerhead turtle (Caretta caretta) movement patterns and Mediterranean currents. Mar Biol 151:1605-1614

Bertolero A (2003) Varamientos y capturas de tortugas marinas en los alrededores del Delta del Ebro (NE España) entre los años 1984 y 2001. Rev Esp Herpetol 17:39-54

Bitón Porsmoguer S, Merchán Fornelio M, Tomás J (2011) Assessing the use of Turtle Excluder Devices (TEDs) in bottom trawlers in the western Mediterranean Sea: a preliminary study. Mar Turtle Newsl 131:15-16

Bjorndal KA, Wetherall JA, Bolten AB, Mortimer JA (1999) Twenty-six years of green turtle nesting at Tortuguero, Costa Rica: an encouraging trend. Conserv Biol 13: 126-134

Blasi MF, Mattei D (2017) Seasonal encounter rate, life stages and main threats to the loggerhead sea turtle (Caretta caretta) in the Aeolian Archipelago (southern Thyrrenian Sea). Aquat Conserv 27:617-630

Blasi MF, Roscioni F, Mattei D (2016) Interaction of loggerhead turtles (Caretta caretta) with traditional fish aggregating devices (FADs) in the Mediterranean Sea. Herpetol Conserv Biol 11:386-401

Bolten AB (1999) Techniques for measuring sea turtles. In: Eckert KL, Bjorndal KA, Abreu-Grobois FA, Donnelly M (eds) Research and management techniques for the conservation of sea turtles. IUCN/SSC Marine Turtle Specialist Group, Washington, DC, p 110-114

Bradshaw PJ, Broderick AC, Carreras C, Inger R and others (2017) Satellite tracking and stable isotope analysis highlight differential recruitment among foraging areas in green turtles. Mar Ecol Prog Ser 582:201-214

* Bradshaw PJ, Broderick AC, Carreras C, Fuller W, Snape R, Wright LI, Godley BJ (2018) Defining conservation units with enhanced molecular tools to reveal fine scale structuring among Mediterranean green turtle rookeries. Biol Conserv 222:253-260

Broderick AC, Godley BJ (1996) Population and nesting ecology of the green turtle, Chelonia mydas, and the loggerhead turtle, Caretta caretta, in northern Cyprus. Zool Middle East 13:27-46

Broderick AC, Hancock EG (1997) Insect infestation of Mediterranean marine turtle eggs. Herpetol Rev 28: 190-191

Broderick AC, Godley BJ, Reece S, Downie JR (2000) Incubation periods and sex ratios of green turtles: highly female biased hatchling production in the eastern Mediterranean. Mar Ecol Prog Ser 202:273-281

* Broderick AC, Glen F, Godley BJ, Hays GC (2002) Estimating the number of green and loggerhead turtles nesting annually in the Mediterranean. Oryx 36:227-235

* Broderick AC, Glen F, Godley BJ, Hays GC (2003) Variation in reproductive output of marine turtles. J Exp Mar Biol Ecol 288:95-109

Broderick AC, Coyne MS, Fuller WJ, Glen F, Godley BJ (2007) Fidelity and over-wintering of sea turtles. Proc R Soc B 274:1533-1538

* Bucchia M, Camacho M, Santos MRD, Boada LD and others (2015) Plasma levels of pollutants are much higher in loggerhead turtle populations from the Adriatic Sea than in those from open waters (Eastern Atlantic Ocean). Sci Total Environ 523:161-169

* Cambiè G (2011) Incidental capture of Caretta caretta in trammel nets off the western coast of Sardinia (Italy): statistical models of capture abundance and immediate survival. Aquat Conserv 21:28-36

Cambiè G, Muiño R, Freire J, Mingozzi T (2012) Effects of small (13/0) circle hooks on loggerhead sea turtle bycatch in a small-scale, italian pelagic longline fishery. Bull Mar Sci 88:719-730

Camiñas JA, De La Serna JM (1995) The loggerhead distribution in the western Mediterranean Sea as deduced from captures by the Spanish long line fishery. In: Llorente GA, Montori A, Santos X, Carretero MA (eds) Scientia Herpetologica, Barcelona, p 316-323

Canbolat AF (2004) A review of sea turtle nesting activity along the Mediterranean coast of Turkey. Biol Conserv 116:81-91

Candan O, Kolankaya D (2016) Sex ratio of green turtle (Chelonia mydas) hatchlings at Sugözü, Turkey: higher accuracy with pivotal incubation duration. Chelonian Conserv Biol 15:102-108

* Cardona L, Hays GC (2018) Ocean currents, individual movements and genetic structuring of populations. Mar Biol 165:10

* Cardona L, Revelles M, Carreras C, San Felix M, Gazo M, Aguilar A (2005) Western Mediterranean immature loggerhead turtles: habitat use in spring and summer assessed through satellite tracking and aerial surveys. Mar Biol 147:583-591

* Cardona L, Revelles M, Parga ML, Tomás J and others (2009) Habitat use by loggerhead sea turtles Caretta caretta off the coast of eastern Spain results in a high vulnerability to neritic fishing gear. Mar Biol 156:2621-2630

Cardona L, Campos P, Levy Y, Demetropoulos A, Margaritoulis D (2010) Asynchrony between dietary and nutritional shifts during the ontogeny of green turtles (Chelonia mydas) in the Mediterranean. J Exp Mar Biol Ecol 393:83-89

* Cardona L, Clusa M, Eder E, Demetropoulos A and others (2014) Distribution patterns and foraging ground productivity determine clutch size in Mediterranean loggerhead turtles. Mar Ecol Prog Ser 497:229-241

Carr A (1954) The passing of the fleet. AIBS Bull 4:17-19

Carreras C, Cardona L, Aguilar A (2004) Incidental catch of the loggerhead turtle Caretta caretta off the Balearic Islands (western Mediterranean). Biol Conserv 117:321-329

Carreras C, Pont S, Maffucci F, Pascual M and others (2006) Genetic structuring of immature loggerhead sea turtles (Caretta caretta) in the Mediterranean Sea reflects water circulation patterns. Mar Biol 149:1269-1279 
Carreras C, Pascual M, Cardona L, Aguilar A and others (2007) The genetic structure of the loggerhead sea turtle (Caretta caretta) in the Mediterranean as revealed by nuclear and mitochondrial DNA and its conservation implications. Conserv Genet 8:761-775

Carreras C, Pascual M, Cardona L, Marco A and others (2011) Living together but remaining apart: Atlantic and Mediterranean loggerhead sea turtles (Caretta caretta) in shared feeding grounds. J Hered 102:666-677

Carreras C, Monzón-Argüello C, López-Jurado LF, Calabuig $\mathrm{P}$ and others (2014) Origin and dispersal routes of foreign green and Kemp's ridley turtles in Spanish Atlantic and Mediterranean waters. Amphib-Reptil 35: 73-86

* Casale P (2011) Sea turtle by-catch in the Mediterranean. Fish Fish 12:299-316

Casale P (2015) Caretta caretta (Mediterranean subpopulation). The IUCN Red List of Threatened Species 2015: e.T83644804A83646294. www.iucnredlist.org (accessed 26 December 2016)

Casale P, Heppell SS (2016) How much sea turtle bycatch is too much? A stationary age distribution model for simulating population abundance and potential biological removal in the Mediterranean. Endang Species Res 29: 239-254

Casale P, Margaritoulis D (2010) Sea turtles in the Mediterranean: distribution, threats and conservation priorities. IUCN, Gland

Casale P, Mariani P (2014) The first 'lost year' of Mediterranean sea turtles: dispersal patterns indicate subregional management units for conservation. Mar Ecol Prog Ser 498:263-274

Casale P, Simone G (2017) Seasonal residency of loggerhead turtles Caretta caretta tracked from the Gulf of Manfredonia, South Adriatic. Mediterr Mar Sci 18:4-10

Casale P, Gerosa G, Yerli SV (2000) Female-biased primary sex ratio of the green turtle, Chelonia mydas, estimated through sand temperatures at Akyatan, Turkey. Zool Middle East 20:37-46

Casale P, Laurent L, Gerosa G, Argano R (2002) Molecular evidence of male-biased dispersal in loggerhead turtle juveniles. J Exp Mar Biol Ecol 267:139-145

Casale P, Nicolosi P, Freggi D, Turchetto M, Argano R (2003) Leatherback turtles (Dermochelys coriacea) in Italy and in the Mediterranean Basin. Herpetol J 13:135-139

* Casale P, Laurent L, De Metrio G (2004) Incidental capture of marine turtles by the Italian trawl fishery in the north Adriatic Sea. Biol Conserv 119:287-295

Casale P, Freggi D, Basso R, Argano R (2005) Size at male maturity, sexing methods and adult sex ratio in loggerhead turtles (Caretta caretta) from Italian waters investigated through tail measurements. Herpetol J 15: 145-148

Casale P, Lazar B, Pont S, Tomás J and others (2006) Sex ratios of juvenile loggerhead sea turtles Caretta caretta in the Mediterranean Sea. Mar Ecol Prog Ser 324: 281-285

Casale P, Freggi D, Basso R, Vallini C, Argano R (2007a) A model of area fidelity, nomadism, and distribution patterns of loggerhead sea turtles (Caretta caretta) in the Mediterranean Sea. Mar Biol 152:1039-1049

Casale P, Mazaris AD, Freggi D, Basso R, Argano R (2007b) Survival probabilities of loggerhead sea turtles (Caretta caretta) estimated from capture-mark-recapture data in the Mediterranean Sea. Sci Mar 71:365-372
Casale P, Abbate G, Freggi D, Conte N, Oliverio M, Argano R (2008a) Foraging ecology of loggerhead sea turtles Caretta caretta in the central Mediterranean Sea: evidence for a relaxed life history model. Mar Ecol Prog Ser 372:265-276

Casale P, Freggi D, Rocco M (2008b) Mortality induced by drifting longline hooks and branchlines in loggerhead sea turtles, estimated through observation in captivity. Aquat Conserv 18:945-954

Casale P, d'Astore PP, Argano R (2009a) Age at size and growth rates of early juvenile loggerhead sea turtles (Caretta caretta) in the Mediterranean based on length frequency analysis. Herpetol J 19:29-33

Casale P, Mazaris AD, Freggi D, Vallini C, Argano R (2009b) Growth rates and age at adult size of loggerhead sea turtles (Caretta caretta) in the Mediterranean Sea, estimated through capture-mark-recapture records. Sci Mar 73: 589-595

Casale P, Affronte M, Insacco G, Freggi D and others (2010a) Sea turtle strandings reveal high anthropogenic mortality in Italian waters. Aquat Conserv 20: 611-620

Casale P, Margaritoulis D, Aksissou M Aureggi M and others (2010b) Overview. In: Casale P, Margaritoulis D (eds) Sea turtles in the Mediterranean: distribution, threats and conservation priorities. IUCN, Gland, p 1-14

* Casale P, Conte N, Freggi D, Cioni C, Argano R (2011a) Age and growth determination by skeletochronology in loggerhead sea turtles (Caretta caretta) from the Mediterranean Sea. Sci Mar 75:197-203

Casale P, Mazaris AD, Freggi D (2011b) Estimation of age at maturity of loggerhead sea turtles Caretta caretta in the Mediterranean using length-frequency data. Endang Species Res 13:123-129

* Casale P, Affronte M, Scaravelli D, Lazar B, Vallini C, Luschi $P$ (2012a) Foraging grounds, movement patterns and habitat connectivity of juvenile loggerhead turtles (Caretta caretta) tracked from the Adriatic Sea. Mar Biol 159:1527-1535

* Casale P, Aprea A, Deflorio M, De Metrio G (2012b) Increased by-catch rates in the Gulf of Taranto, Italy, in 20 years: a clue about sea turtle population trends? Chelonian Conserv Biol 11:239-243

Casale P, Broderick AC, Freggi D, Mencacci R, Fuller WJ, Godley BJ, Luschi P (2012c) Long-term residence of juvenile loggerhead turtles to foraging grounds: a potential conservation hotspot in the Mediterranean. Aquat Conserv 22:144-154

Casale P, Palilla G, Salemi A, Napoli A and others (2012d) Exceptional sea turtle nest records in 2011 suggest an underestimated nesting potential in Sicily (Italy). Acta Herpetol 7:181-188

Casale P, Simone G, Conoscitore C, Conoscitore M, Salvemini P (2012e) The Gulf of Manfredonia: a new neritic foraging area for loggerhead sea turtles in the Adriatic Sea. Acta Herpetol 7:1-12

Casale P, Freggi D, Cinà A, Rocco M (2013a) Spatio-temporal distribution and migration of adult male loggerhead sea turtles (Caretta caretta) in the Mediterranean Sea: further evidence of the importance of neritic habitats off North Africa. Mar Biol 160:703-718

Casale P, Freggi D, Dourdeville KM, Prescott R (2013b) First evidence of migration by loggerhead sea turtles, Caretta Caretta, from the eastern Mediterranean to North America. Vie Milieu 63:93-96 
Casale P, Freggi D, Maffucci F, Hochscheid S (2014) Adult sex ratios of loggerhead sea turtles (Caretta caretta) in two Mediterranean foraging grounds. Sci Mar 78:303-309

Casale P, Freggi D, Furii G, Vallini C and others (2015) Annual survival probabilities of juvenile loggerhead sea turtles indicate high anthropogenic impact on Mediterranean populations. Aquat Conserv 25:690-700

* Casale P, Freggi D, Paduano V, Oliverio M (2016) Biases and best approaches for assessing debris ingestion in sea turtles, with a case study in the Mediterranean. Mar Pollut Bull 110:238-249

Casale P, Freggi D, Rigoli A, Ciccocioppo A, Luschi P (2017) Geometric morphometrics, scute patterns and biometrics of loggerhead turtles (Caretta caretta) in the central Mediterranean. Amphib-Reptil 38:145-156

Clusa M, Carreras C, Pascual M, Demetropoulos A and others (2013) Mitochondrial DNA reveals Pleistocenic colonisation of the Mediterranean by loggerhead turtles (Caretta caretta). J Exp Mar Biol Ecol 439:15-24

Clusa M, Carreras C, Pascual M, Gaughran SJ and others (2014) Fine-scale distribution of juvenile Atlantic and Mediterranean loggerhead turtles (Caretta caretta) in the Mediterranean Sea. Mar Biol 161:509-519

Clusa M, Carreras C, Cardona L, Demetropoulos A and others (2018) Philopatry in loggerhead turtles (Caretta caretta): beyond the gender paradigm. Mar Ecol Prog Ser 588:201-213

Coelho R, Fernandez-Carvalho J, Santos MN (2013) A review of fisheries within the ICCAT convention area that interact with sea turtles. International Commission for the Conservation of Atlantic Tunas. Collect Vol Sci Pap 69:1788-1827

Coll M, Carreras M, Cornax MJ, Massutí E and others (2014) Closer to reality: reconstructing total removals in mixed fisheries from Southern Europe. Fish Res 154:179-194

Cox TM, Lewison RL, Zydelis R, Crowder LB, Safina C, Read AJ (2007) Comparing effectiveness of experimental and implemented bycatch reduction measures: the ideal and the real. Conserv Biol 21:1155-1164

Crouse DT, Crowder LB, Caswell H (1987) A stage-based population model for loggerhead sea turtles and implications for conservation. Ecology 68:1412-1423

D'Ilio S, Mattei D, Blasi MF, Alimonti A, Bogialli S (2011) The occurrence of chemical elements and POPs in loggerhead turtles (Caretta caretta): an overview. Mar Pollut Bull 62:1606-1615

* Darmon G, Miaud C, Claro F, Doremus G, Galgani F (2017) Risk assessment reveals high exposure of sea turtles to marine debris in French Mediterranean and metropolitan Atlantic waters. Deep Sea Res II 141:319-328

Delgado C, Canario AVM, Dellinger T (2010) Sex ratios of loggerhead sea turtles Caretta caretta during the juvenile pelagic stage. Mar Biol 157:979-990

Demetropoulos A, Hadjichristophorou M (1989) Sea turtle conservation in Cyprus. Mar Turtle Newsl 44:4-6

Demetropoulos A, Hadjichristophorou M (1995) Manual on marine turtle conservation in the Mediterranean. UNEP(MAP)SPA/IUCN/CWS/Fishery Department MANRE, Cyprus

Demetropoulos A, Hadjichristophorou M (2009) The Cyprus Turtle Conservation Project -29 years on. In: Demetropoulos A, Türkozan O (eds) Proceedings of the 2nd Mediterranean conference on marine turtles. Barcelona Convention - Bern Convention - Bonn Convention (CMS), p 19-26
Demetropoulos A, Hadjichristophorou M (2010) Cyprus Region B. In: Casale P, Margaritoulis D (eds) Sea turtles in the Mediterranean: distribution, threats and conservation priorities. IUCN, Gland, p 53-64

*Dimitriadis C, Fournari-Konstantinidou I, Sourbès L, Koutsoubas D, Mazaris AD (2018) Reduction of sea turtle population recruitment caused by nightlight: evidence from the Mediterranean region. Ocean Coast Manage 153: 108-115

Dimopoulos D (2001) The National Marine Park of Zakynthos: a refuge for the loggerhead turtle in the Mediterranean. Mar Turtle Newsl 93:5-9

Dodd CKJ (1988) Synopsis of the biological data on the loggerhead sea turtle Caretta caretta (Linnaeus 1758). US Fish Wildl Serv Biol Rep 88(14)

* Domènech F, Álvarez de Quevedo I, Merchán M, Revuelta $\mathrm{O}$ and others (2015) Incidental catch of marine turtles by Spanish bottom trawlers in the western Mediterranean. Aquat Conserv 25:678-689

* Dujon AM, Lindstrom RT, Hays GC (2014) The accuracy of Fastloc-GPS locations and implications for animal tracking. Methods Ecol Evol 5:1162-1169

Dujon AM, Schofield G, Lester RE, Esteban N, Hays GC (2017) Fastloc-GPS reveals daytime departure and arrival during long-distance migration and the use of different resting strategies in sea turtles. Mar Biol 164:187

* Duncan EM, Botterell ZLR, Broderick AC, Galloway TS, Lindeque PK, Nuno A, Godley BJ (2017) A global review of marine turtle entanglement in anthropogenic debris: a baseline for further action. Endang Species Res 34:431-448

Echwikhi K, Jribi I, Bradai MN, Bouain A (2010) Gillnet fishery - loggerhead turtle interactions in the Gulf of Gabes, Tunisia. Herpetol J 20:25-30

Echwikhi K, Jribi I, Bradai MN, Bouain A (2012) Overview of loggerhead turtles coastal nets interactions in the Mediterranean Sea. Aquat Conserv 22:827-835

Eckert SA, Moore JE, Dunn DC, van Buiten RS, Eckert KL, Halpin PN (2008) Modeling loggerhead turtle movement in the Mediterranean: importance of body size and oceanography. Ecol Appl 18:290-308

Environmental Justice Foundation (2007) Illegal driftnetting in the Mediterranean. Environmental Justice Foundation, London

*Encalada SE, Lahanas PN, Bjorndal KA, Bolten AB, Miyamoto MM, Bowen BW (1996) Phylogeography and population structure of the Atlantic and Mediterranean green turtle Chelonia mydas: a mitochondrial DNA control region sequence assessment. Mol Ecol 5:473-483

Encalada SE, Bjorndal KA, Bolten AB, Zurita JC and others (1998) Population structure of loggerhead turtle (Caretta caretta) nesting colonies in the Atlantic and Mediterranean as inferred from mitochondrial DNA control region sequences. Mar Biol 130:567-575

*Erk'akan F (1993) Nesting biology of loggerhead turtles Caretta caretta L. on Dalyan beach, Mugla-Turkey. Biol Conserv 66:1-4

Fahlman A, Crespo-Picazo JL, Sterba-Boatwright B, Stacy BA, Garcia-Parraga D (2017) Defining risk variables causing gas embolism in loggerhead sea turtles (Caretta caretta) caught in trawls and gillnets. Sci Rep 7:2739

FAO (2009) Guidelines to reduce sea turtle mortality in fishing operations. FAO, Rome

FAO (2016) The state of Mediterranean and Black Sea fisheries 2016. General Fisheries Commission for the Mediterranean FAO, Rome 
Fergusson IK, Compagno LJV, Marks MA (2000) Predation by white sharks Carcharodon carcharias (Chondrichthyes: Lamnidae) upon chelonians, with new records from the Mediterranean Sea and a first record of the ocean sunfish Mola mola (Osteichthyes: Molidae) as stomach contents. Environ Biol Fishes 58:447-453

Franzellitti S, Locatelli C, Gerosa G, Vallini C, Fabbri E (2004) Heavy metals in tissues of loggerhead turtles (Caretta caretta) from the northwestern Adriatic Sea. Comp Biochem Physiol C Toxicol Pharmacol 138:187-194

Fuller WJ, Broderick AC, Phillips RA, Silk JRD, Godley BJ (2008) Utility of geolocating light loggers for indicating at-sea movements in sea turtles. Endang Species Res 4: 139-146

Fuller WJ, Broderick AC, Hooker SK, Witt MJ, Godley BJ (2009) Insights into habitat utilization by green turtles (Chelonia mydas) during the inter-nesting period using animal-borne digital cameras. Mar Technol Soc J 43: 51-59

Fuller WJ, Broderick AC, Glen F, Kusetogullari H, Godley BJ (2010) Cyprus - Region A. In: Casale P, Margaritoulis $\mathrm{D}$ (eds) Sea turtles in the Mediterranean: distribution, threats and conservation priorities. IUCN, Gland, p 41-51

Fuller WJ, Godley BJ, Hodgson DJ, Reece SE, Witt MJ, Broderick AC (2013) Importance of spatio-temporal data for predicting the effects of climate change on marine turtle sex ratios. Mar Ecol Prog Ser 488:267-274

García-Párraga D, Crespo-Picazo JL, Bernaldo de Quirós Y, Cervera V and others (2014) Decompression sickness ('the bends') in sea turtles. Dis Aquat Org 111:191-205

* Garofalo L, Mingozzi T, Mico A, Novelletto A (2009) Loggerhead turtle (Caretta caretta) matrilines in the Mediterranean: further evidence of genetic diversity and connectivity. Mar Biol 156:2085-2095

Garofalo L, Mastrogiacomo A, Casale P, Carlini R and others (2013) Genetic characterization of central Mediterranean stocks of the loggerhead turtle (Caretta caretta) using mitochondrial and nuclear markers, and conservation implications. Aquat Conserv 23:868-884

Geldiay R, Koray T, Balik S (1982) Status of sea turtle populations (Caretta c. caretta and Chelonia m. mydas) in the northern Mediterranean Sea, Turkey. In: Bjorndal KA (ed) Biology and conservation of sea turtles. Smithsonian Institution Press, Washington, DC, p 425-434

Gerosa G, Aureggi M (2001) Sea turtle handling guidebook for fishermen. RAC/SPA, UNEP, Tunis

Gilman E, Huang HW (2017) Review of effects of pelagic longline hook and bait type on sea turtle catch rate, anatomical hooking position and at-vessel mortality rate. Rev Fish Biol Fish 27:43-52

Godley BJ, Thompson DR, Waldron S, Furness RW (1998) The trophic status of marine turtles as determined by stable isotope analysis. Mar Ecol Prog Ser 166:277-284

*Godley BJ, Thompson DR, Furness RW (1999) Do heavy metal concentrations pose a threat to marine turtles from the Mediterranean Sea? Mar Pollut Bull 38:497-502

* Godley BJ, Broderick AC, Downie JR, Glen F and others (2001a) Thermal conditions in nests of loggerhead turtles: further evidence suggesting female skewed sex ratios of hatchling production in the Mediterranean. J Exp Mar Biol Ecol 263:45-63

Godley BJ, Broderick AC, Mrosovsky N (2001b) Estimating hatchling sex ratios of loggerhead turtles in Cyprus from incubation durations. Mar Ecol Prog Ser 210:195-201
Godley BJ, Broderick AC, Frauenstein R, Glen F, Hays GC (2002a) Reproductive seasonality and sexual dimorphism in green turtles. Mar Ecol Prog Ser 226:125-133

* Godley BJ, Richardson S, Broderick AC, Coyne MS, Glen F, Hays GC (2002b) Long-term satellite telemetry of the movements and habitat utilisation by green turtles in the Mediterranean. Ecography 25:352-362

Godley BJ, Broderick AC, Glen F, Hays GC (2003) Post-nesting movements and submergence patterns of loggerhead marine turtles in the Mediterranean assessed by satellite tracking. J Exp Mar Biol Ecol 287:119-134

* Gómez de Segura A, Tomás J, Pedraza SN, Crespo EA, Raga JA (2006) Abundance and distribution of the endangered loggerhead turtle in Spanish Mediterranean waters and the conservation implications. Anim Conserv 9:199-206

Groombridge B (1990) Marine turtles in the Mediterranean: distribution, population status, conservation. Report to the Council of Europe, Environment Conservation and Management Division, Nature and Environment Series No. 48 , Strasbourg

*Hamann M, Godfrey MH, Seminoff JA, Arthur K and others (2010) Global research priorities for sea turtles: informing management and conservation in the 21st century. Endang Species Res 11:245-269

Hamza A (2010) Libya. In: Casale P, Margaritoulis D (eds) Sea turtles in the Mediterranean: distribution, threats and conservation priorities. IUCN, Gland, p 157-170

Haxhiu I (2010) Albania. In: Casale P, Margaritoulis D (eds) Sea turtles in the Mediterranean: distribution, threats and conservation priorities. IUCN, Gland, p 15-28

Hays GC, Scott R (2013) Global patterns for upper ceilings on migration distance in sea turtles and comparisons with fish, birds and mammals. Funct Ecol 27:748-756

*Hays GC, Ashworth JS, Barnsley MJ, Broderick AC and others (2001) The importance of sand albedo for the thermal conditions on sea turtle nesting beaches. Oikos 93:87-94

*Hays GC, Glen F, Broderick AC, Godley BJ, Metcalfe JD (2002) Behavioural plasticity in a large marine herbivore: contrasting patterns of depth utilisation between two green turtle (Chelonia mydas) populations. Mar Biol 141: 985-990

KHays GC, Fossette S, Katselidis KA, Mariani P, Schofield G (2010a) Ontogenetic development of migration: Lagrangian drift trajectories suggest a new paradigm for sea turtles. J R Soc Interface 7:1319-1327

*Hays GC, Fossette S, Katselidis KA, Schofield G, Gravenor MB (2010b) Breeding periodicity for male sea turtles, operational sex ratios, and implications in the face of climate change. Conserv Biol 24:1636-1643

* Hays GC, Christensen A, Fossette S, Schofield G, Talbot J, Mariani P (2014a) Route optimisation and solving Zermelo's navigation problem during long distance migration in cross flows. Ecol Lett 17:137-143

* Hays GC, Mazaris AD, Schofield G (2014b) Different male vs. female breeding periodicity helps mitigate offspring sex ratio skews in sea turtles. Front Mar Sci 1:43

Hays GC, Mazaris AD, Schofield G, Laloë JO (2017) Population viability at extreme sex-ratio skews produced by temperature-dependent sex determination. Proc R Soc B 284:20162576

* Hazel J, Gyuris E (2006) Vessel-related mortality of sea turtles in Queensland, Australia. Wildl Res 33:149-154

Hazel J, Lawler IR, Marsh H, Robson S (2007) Vessel speed increases collision risk for the green turtle Chelonia mydas. Endang Species Res 3:105-113 
Heppell SS, Crowder LB, Crouse DT, Epperly SP, Frazer NB (2003) Population models for Atlantic loggerheads: past, present, and future. In: Bolten AB, Witherington BE (eds) Loggerhead sea turtles. Smithsonian Books, Washington, DC, p 255-273

Hochscheid S, Bentivegna F, Speakman JR (2004) Longterm cold acclimation leads to high $\mathrm{Q}_{10}$ effects on oxygen consumption of loggerhead sea turtles caretta caretta. Physiol Biochem Zool 77:209-222

Hochscheid S, Bentivegna F, Hays GC (2005) First records of dive durations for a hibernating sea turtle. Biol Lett 1: 82-86

Hochscheid S, Bentivegna F, Bradai MN, Hays GC (2007) Overwintering behaviour in sea turtles: dormancy is optional. Mar Ecol Prog Ser 340:287-298

Hochscheid S, Bentivegna F, Hamza A, Hays GC (2010) When surfacers do not dive: multiple significance of extended surface times in marine turtles. J Exp Biol 213: 1328-1337

Hochscheid S, Travaglini A, Maffucci F, Hays GC, Bentivegna F (2013) Since turtles cannot talk: What beak movement sensors can tell us about the feeding ecology of neritic loggerhead turtles, Caretta caretta. Mar Ecol 34:321-333

Hornell J (1935) Report on fisheries of Palestine. Crown Agents for the Colonies, Millbank, London

Houghton JDR, Woolmer A, Hays GC (2000) Sea turtle diving and foraging behaviour around the Greek Island of Kefalonia. J Mar Biol Assoc UK 80:761-762

Ilgaz Ç, Türkozan O, Özdemir A, Kaska Y, Stachowitsch M (2007) Population decline of loggerhead turtles: two potential scenarios for Fethiye beach, Turkey. Biodivers Conserv 16:1027-1037

Jackson AL, Broderick AC, Fuller WJ, Glen F, Ruxton GD, Godley BJ (2008) Sampling design and its effect on population monitoring: How much monitoring do turtles really need? Biol Conserv 141:2932-2941

Jribi I, Bradai MN (2014) Sex ratio estimations of loggerhead sea turtle hatchlings at Kuriat Islands, Tunisia: Can minor nesting sites contribute to compensate globally female-biased sex ratio? Sci World J 2014:419410

Kamezaki N (2003) What is a loggerhead turtle? The morphological perspective. In: Bolten $A B$, Witherington $B$ (eds) Loggerhead sea turtles. Smithsonian Institution Press, Washington, DC, p 28-43

Karaa S, Maffucci F, Jribi I, Bologna MA and others (2016) Connectivity and stock composition of loggerhead turtles foraging on the North African continental shelf (Central Mediterranean): implications for conservation and management. Mar Ecol 37:1103-1115

Kaska Y (2000) Genetic structure of Mediterranean sea turtle populations. Turk J Zool 24:191-197

Kaska Y, Downie R, Tippett R, Furness RW (1998) Natural temperature regimes for loggerhead and green turtle nests in the eastern Mediterranean. Can J Zool 76: 723-729

Kaska Y, Çelik A, Bağ H, Aureggi M and others (2004) Heavy metal monitoring in stranded sea turtles along the Mediterranean coast of Turkey. Fresenius Environ Bull 13:769-776

Kaska Y, Ilgaz Ç, Özdemir A, Başkale E, Türkozan O, Baran İ, Stachowitsch M (2006) Sex ratio estimations of loggerhead sea turtle hatchlings by histological examination and nest temperatures at Fethiye beach, Turkey. Naturwissenschaften 93:338-343
Kaska Y, Başkale E, Urhan R, Katılmış Y and others (2010) Natural and anthropogenic factors affecting the nest-site selection of loggerhead turtles, Caretta caretta, on Dalaman-Sarigerme beach in south-west Turkey. Zool Middle East 50:47-58

Kaska Y, Şahin B, Başkale E, Sarı F, Owczarczak S (2011) Sea Turtle Research and Rehabilitation Centre (DEKAMER), Dalyan, Mugla, Turkey. Mar Turtle Newsl 131:16-17

Kasparek M, Godley BJ, Broderick AC (2001) Nesting of the green turtle, Chelonia mydas, in the Mediterranean: a review of status and conservation needs. Zool Middle East 24:45-74

Katılmış Y, Urhan R, Kaska Y, Başkale E (2006) Invertebrate infestation on eggs and hatchlings of the loggerhead turtle, Caretta caretta, in Dalaman, Turkey. Biodivers Conserv 15:3721-3730

Katselidis KA, Schofield G, Stamou G, Dimopoulos P, Pantis JD (2012) Females first? Past, present and future variability in offspring sex ratio at a temperate sea turtle breeding area. Anim Conserv 15:508-518

Katselidis KA, Schofield G, Stamou G, Dimopoulos P, Pantis JD (2013) Evidence-based management to regulate the impact of tourism at a key marine turtle rookery on Zakynthos Island, Greece. Oryx 47:584-594

Katselidis KA, Schofield G, Stamou G, Dimopoulos P, Pantis JD (2014) Employing sea-level rise scenarios to strategically select sea turtle nesting habitat important for longterm management at a temperate breeding area. J Exp Mar Biol Ecol 450:47-54

Laurent L, Lescure J (1994) L'hivernage des tortues caouannes Caretta caretta (L.) dans le sud Tunisien. Rev Ecol Terre Vie 49:63-86

Lauriano G, Panigada S, Casale P, Pierantonio N, Donovan GP (2011) Aerial survey abundance estimates of the loggerhead sea turtle Caretta caretta in the Pelagos Sanctuary, northwestern Mediterranean Sea. Mar Ecol Prog Ser 437:291-302

KLauritsen AM, Dixon PM, Cacela D, Brost B and others (2017) Impact of the Deepwater Horizon oil spill on loggerhead turtle Caretta caretta nest densities in northwest Florida. Endang Species Res 33:83-93

Lazar B, Casale P, Tvrtković N, Kozul V, Tutman P, Glavic N (2004a) The presence of the green sea turtle, Chelonia mydas, in the Adriatic Sea. Herpetol J 14:143-147

*Lazar B, Margaritoulis D, Tvrtković N (2004b) Tag recoveries of the loggerhead sea turtle Caretta caretta in the eastern Adriatic Sea: implications for conservation. J Mar Biol Assoc UK 84:475-480

Lazar B, Zuljevic A, Holcer D (2010) Diet composition of a green turtle, Chelonia mydas, from the Adriatic Sea. Natura Croat 19:263-271

* Lazar B, Gračan R, Katić J, Zavodnik D, Jaklin A, Tvrtković N (2011a) Loggerhead sea turtles (Caretta caretta) as bioturbators in neritic habitats: an insight through the analysis of benthic molluscs in the diet. Mar Ecol 32: 65-74

Lazar B, Maslov L, Romanic SH, Gračan R, Krauthacker B, Holcer D, Tvrtković N (2011b) Accumulation of organochlorine contaminants in loggerhead sea turtles, Caretta caretta, from the eastern Adriatic Sea. Chemosphere 82: 121-129

Lee PLM, Schofield G, Haughey RI, Mazaris AD, Hays GC (2017) A review of patterns of multiple paternity across sea turtle rookeries. Adv Mar Biol, https://doi.org/10. 1016/bs.amb.2017.09.004 
Levy Y (2010) Israel. In: Casale P, Margaritoulis D (eds) Sea turtles in the Mediterranean: distribution, threats and conservation priorities. IUCN, Gland, p 113-133

* Levy Y, Keren T, Leader N, Weil G, Tchernov D, Rilov G (2017) Spatiotemporal hotspots of habitat use by loggerhead (Caretta caretta) and green (Chelonia mydas) sea turtles in the Levant Basin as tools for conservation. Mar Ecol Prog Ser 575:165-179

Lucchetti A, Punzo E, Virgili M (2016) Flexible Turtle Excluder Device (TED): An effective tool for Mediterranean coastal multispecies bottom trawl fisheries. Aquat Living Resour 29:201

Lucchetti A, Vasapollo C, Virgili M (2017) An interviewbased approach to assess sea turtle bycatch in Italian waters. PeerJ 5:e3151

Luschi P, Casale P (2014) Movement patterns of marine turtles in the Mediterranean Sea: a review. Ital J Zool 81:478-495

Kuschi P, Mencacci R, Vallini C, Ligas A, Lambardi P, Benvenuti $S$ (2013) Long-term tracking of adult loggerhead turtles (Caretta caretta) in the Mediterranean Sea. J Herpetol 47:227-231

* Luschi P, Mencacci R, Cerritelli G, Papetti L, Hochscheid S (2018) Large-scale movements in the oceanic environment identify important foraging areas for loggerheads in central Mediterranean Sea. Mar Biol 165:4

Maffucci F, Kooistra W, Bentivegna F (2006) Natal origin of loggerhead turtles, Caretta caretta, in the neritic habitat off the Italian coasts, Central Mediterranean. Biol Conserv 127:183-189

* Maffucci F, D'Angelo I, Hochscheid S, Ciampa M and others (2013) Sex ratio of juvenile loggerhead turtles in the Mediterranean Sea: Is it really 1:1? Mar Biol 160:1097-1107

Maffucci F, Corrado R, Palatella L, Borra M and others (2016) Seasonal heterogeneity of ocean warming: a mortality sink for ectotherm colonizers. Sci Rep 6:23983

Margaritoulis D (1982) Observations on loggerhead sea turtle (Caretta caretta) activity during three nesting seasons (1977-1979) in Zakynthos, Greece. Biol Conserv 24: 193-204

Margaritoulis D (1985) Preliminary observations on the breeding behaviour and ecology of Caretta caretta in Zakynthos, Greece. Biol Gallo-Hell 10:323-332

Margaritoulis D (1988a) Nesting of the loggerhead sea turtles Caretta caretta on the shores of Kiparissia Bay, Greece, in 1987. Mésogée 48:59-65

Margaritoulis D (1988b) Post-nesting movements of loggerhead sea turtles tagged in Greece. Rapp P-V Reun Comm Int Explor Sci Mer Méditerr 31:284

Margaritoulis D (2005) Nesting activity and reproductive output of loggerhead sea turtles, Caretta caretta, over 19 seasons (1984-2002) at Laganas Bay, Zakynthos, Greece: the largest rookery in the Mediterranean. Chelonian Conserv Biol 4:916-929

Margaritoulis D, Chiras G (2011) Scalation patterns of loggerhead turtles nesting in Laganas Bay, Zakynthos island, Greece. Mar Turtle Newsl 131:29-31

Margaritoulis D, Panagopoulou A (2010) Greece. In: Casale P, Margaritoulis D (eds) Sea turtles in the Mediterranean: distribution, threats and conservation priorities. IUCN, Gland, p 85-112

Margaritoulis D, Rees A (2001) The loggerhead turtle, Caretta caretta, population nesting in Kyparissia Bay, Peloponnesus, Greece: results of beach surveys over seventeen seasons and determination of the core nesting habitat. Zool Middle East 24:75-90
Margaritoulis D, Rees AF (2011) Loggerhead turtles nesting at Rethymno, Greece, prefer the Aegean Sea as their main foraging area. Mar Turtle Newsl 131:12-14

Margaritoulis D, Touliatou S (2011) Mediterranean monk seals present an ongoing threat for loggerhead sea turtles in Zakynthos. Mar Turtle Newsl 131:18-23

Margaritoulis D, Argano R, Baran I, Bentivegna F and others (2003) Loggerhead turtles in the Mediterranean Sea: present knowledge and conservation perspectives. In: Bolten AB, Witherington B (eds) Loggerhead sea turtles. Smithsonian Institution Press, Washington, DC, p 175-198

Margaritoulis D, Rees AF, Dean CJ, Riggall T (2011a) Reproductive data of loggerhead turtles in Laganas Bay, Zakynthos Island, Greece, 2003-2009. Mar Turtle Newsl 131:2-6

Margaritoulis D, Rees AF, Riggall T (2011b) Record nest numbers and increased incidence of neophyte turtles in Kyparissia Bay: positive results from long term nest protection? In: Bentivegna F, Maffucci F, Mauriello V (eds) Book of abstracts, 4th Mediterranean Conference on Marine Turtles, 7-10 November 2011, Naples, p 40

Matiddi M, Hochsheid S, Camedda A, Baini M and others (2017) Loggerhead sea turtles (Caretta caretta): a target species for monitoring litter ingested by marine organisms in the Mediterranean Sea. Environ Pollut 230:199-209

*Mazaris AD, Kornaraki E, Matsinos GY, Margaritoulis D (2004) Modeling the effect of sea surface temperature on sea turtle nesting activities by investigating seasonal trends. Nat Resour Model 17:445-465

* Mazaris AD, Fiksen O, Matsinos YG (2005) Using an individual-based model for assessment of sea turtle population viability. Popul Ecol 47:179-191

*Mazaris AD, Matsinos YG, Margaritoulis D (2006) Nest site selection of loggerhead sea turtles: the case of the island of Zakynthos, W Greece. J Exp Mar Biol Ecol 336:157-162

Mazaris AD, Kallimanis AS, Sgardelis SP, Pantis JD (2008a) Do long-term changes in sea surface temperature at the breeding areas affect the breeding dates and reproduction performance of Mediterranean loggerhead turtles? Implications for climate change. J Exp Mar Biol Ecol 367 : 219-226

Mazaris AD, Matsinos YG, Pantis JD (2008b) Evaluating the effect of varying clutch frequency in nesting trend estimation of sea turtles. Amphib-Reptil 29:361-369

*Mazaris AD, Kallimanis AS, Tzanopoulos J, Sgardelis SP, Pantis JD (2009a) Sea surface temperature variations in core foraging grounds drive nesting trends and phenology of loggerhead turtles in the Mediterranean Sea. J Exp Mar Biol Ecol 379:23-27

*Mazaris AD, Kramer-Schadt S, Tzanopoulos J, Johst K, Matsinos G, Pantis JD (2009b) Assessing the relative importance of conservation measures applied on sea turtles: comparison of measures focusing on nesting success and hatching recruitment success. Amphib-Reptil 30: 221-231

Mazaris AD, Matsinos G, Pantis JD (2009c) Evaluating the impacts of coastal squeeze on sea turtle nesting. Ocean Coast Manage 52:139-145

Mazaris AD, Kallimanis AS, Pantis JD, Hays GC (2013) Phenological response of sea turtles to environmental variation across a species' northern range. Proc R Soc B 280: 20122397

*Mazaris AD, Schofield G, Gkazinou C, Almpanidou V, Hays GC (2017) Global sea turtle conservation successes. Sci Adv 3:e1600730 
Mazor T, Beger M, McGowan J, Possingham HP, Kark S (2016) The value of migration information for conservation prioritization of sea turtles in the Mediterranean. Glob Ecol Biogeogr 25:540-552

McDonald TL, Schroeder BA, Stacy BA, Wallace BP and others (2017) Density and exposure of surface-pelagic juvenile sea turtles to Deepwater Horizon oil. Endang Species Res 33:69-82

* McGowan A, Broderick AC, Deeming J, Godley BJ, Hancock EG (2001) Dipteran infestation of loggerhead (Caretta caretta) and green (Chelonia mydas) sea turtle nests in northern Cyprus. J Nat Hist 35:573-581

McKenzie C, Godley BJ, Furness RW, Wells DE (1999) Concentrations and patterns of organochlorine contaminants in marine turtles from Mediterranean and Atlantic waters. Mar Environ Res 47:117-135

Miller JD (1997) Reproduction in sea turtles. In: Lutz PL, Musick JA (eds) The biology of sea turtles. CRC Marine Science Series, CRC Press, Boca Raton, FL, p 51-81

Millot C (2005) Circulation in the Mediterranean Sea: evidences, debates and unanswered questions. Sci Mar 69: $5-21$

Mingozzi T, Masciari G, Paolillo G, Pisani B, Russo M, Massolo A (2007) Discovery of a regular nesting area of loggerhead turtle Caretta caretta in southern Italy: a new perspective for national conservation. Biodivers Conserv 16:3519-3541

Mingozzi T, Mencacci R, Cerritelli G, Giunchi D, Luschi P (2016) Living between widely separated areas: long-term monitoring of Mediterranean loggerhead turtles sheds light on cryptic aspects of females spatial ecology. J Exp Mar Biol Ecol 485:8-17

Moncada F, Abreu-Grobois FA, Bagley D, Bjorndal KA and others (2010) Movement patterns of loggerhead turtles Caretta caretta in Cuban waters inferred from flipper tag recaptures. Endang Species Res 11:61-68

*Monzón-Argüello C, Rico C, Naro-Maciel E, Varo-Cruz N, López P, Marco A, López-Jurado LF (2010) Population structure and conservation implications for the loggerhead sea turtle of the Cape Verde Islands. Conserv Genet 11:1871-1884

Mrosovsky N (2006) Does the Mediterranean green turtle exist? Mar Turtle Newsl 111:1-2

Mrosovsky N, Kamel S, Rees AF, Margaritoulis D (2002) Pivotal temperature for loggerhead turtles (Caretta caretta) from Kyparissia Bay, Greece. Can J Zool 80:2118-2124

Nada M, Casale P (2010) Egypt. In: Casale P, Margaritoulis $\mathrm{D}$ (eds) Sea turtles in the Mediterranean: distribution, threats and conservation priorities. IUCN, Gland, p 65-76

Nada M, Casale P (2011) Sea turtle bycatch and consumption in Egypt threatens Mediterranean turtle populations. Oryx 45:143-149

Naro-Maciel E, Formia A (2006) Sea turtle subpopulations and the IUCN Red List: a complementary role for conservation genetics. Mar Turtle Newsl 114:6-8

Naro-Maciel E, Reid BN, Alter SE, Amato G and others (2014) From refugia to rookeries: phylogeography of Atlantic green turtles. J Exp Mar Biol Ecol 461:306-316

Nelms SE, Duncan EM, Broderick AC, Galloway TS and others (2016a) Plastic and marine turtles: a review and call for research. ICES J Mar Sci 73:165-181

Nelms SE, Piniak WED, Weir CR, Godley BJ (2016b) Seismic surveys and marine turtles: an underestimated global threat? Biol Conserv 193:49-65

Nolting R, Helder W (1991) Lead and zinc as indicators for atmospheric and riverine particle-transport to sediments in the Gulf of Lions. Oceanol Acta 14:357-367

Novelletto A, Testa L, Iacovelli F, Blasi P, Garofalo L, Mingozzi T, Falconi M (2016) Polymorphism in mitochondrial coding regions of Mediterranean loggerhead turtles: evolutionary relevance and structural effects. Physiol Biochem Zool 89:473-486

Novillo O, Pertusa J, Tomás J (2017) Exploring the presence of pollutants at sea: monitoring heavy metals and pesticides in loggerhead turtles (Caretta caretta) from the western Mediterranean. Sci Total Environ 598:1130-1139

Oliver G (2014) Variabilité et malformations de l'écaillure de la Caouanne, Caretta caretta (Linnaeus, 1758) (Reptilia Cheloniidae), sur les côtes françaises de Méditerranée. Bull Soc Herpetol Fr 150:9-23

Ortiz N, Mangel JC, Wang J, Alfaro-Shigueto J and others (2016) Reducing green turtle bycatch in small-scale fisheries using illuminated gillnets: the cost of saving a sea turtle. Mar Ecol Prog Ser 545:251-259

* Özdemir A, Ilgaz Ç, Kumlutaş Y, Durmuş SH, Kaska Y, Türkozan O (2007) An assessment of initial body size in loggerhead sea turtle (Caretta caretta) hatchlings in Turkey. Zool Sci 24:376-380

Panagopoulou A (2015) Sea turtles and small-scale fisheries: designing conservation policies for a marine area on Crete, Greece. PhD thesis, Drexel University, Philadelphia, PA

Panagopoulou A, Meletis ZA, Margaritoulis D, Spotila JR (2017) Caught in the same net? Small-scale fishermen's perceptions of fisheries interactions with sea turtles and other protected species. Front Mar Sci 4:180

*Parga ML (2012) Hooks and sea turtles: a veterinarian's perspective. Bull Mar Sci 88:731-741

* Patel SH, Morreale SJ, Panagopoulou A, Bailey H and others (2015a) Changepoint analysis: a new approach for revealing animal movements and behaviors from satellite telemetry data. Ecosphere 6:291

* Patel SH, Panagopoulou A, Morreale SJ, Kilham SS and others (2015b) Differences in size and reproductive output of loggerhead turtles Caretta caretta nesting in the eastern Mediterranean Sea are linked to foraging site. Mar Ecol Prog Ser 535:231-241

* Patel SH, Morreale SJ, Saba VS, Panagopoulou A, Margaritoulis D, Spotila JR (2016) Climate impacts on sea turtle breeding phenology in Greece and associated foraging habitats in the wider Mediterranean region. PLOS ONE 11:e0157170

Pierce GJ, Hernandez-Milian G, Santos MB, Dendrinos P and others (2011) Diet of the monk seal (Monachus monachus) in Greek waters. Aquat Mamm 37:284

*Pike DA (2014) Forecasting the viability of sea turtle eggs in a warming world. Glob Chang Biol 20:7-15

Piovano S, Swimmer Y (2017) Effects of a hook ring on catch and bycatch in a Mediterranean swordfish longline fishery: small addition with potentially large consequences. Aquat Conserv 27:372-380

*Piovano S, Clusa M, Carreras C, Giacoma C, Pascual M, Cardona L (2011) Different growth rates between loggerhead sea turtles (Caretta caretta) of Mediterranean and Atlantic origin in the Mediterranean Sea. Mar Biol 158: 2577-2587

* Piovano S, Basciano G, Swimmer Y, Giacoma C (2012) Evaluation of a bycatch reduction technology by fishermen: a case study from Sicily. Mar Policy 36:272-277

* Piroddi C, Gristina M, Zylich K, Greer K, Ulman A, Zeller D, Pauly D (2015) Reconstruction of Italy's marine fisheries 
removals and fishing capacity, 1950-2010. Fish Res 172: 137-147

Pritchard PCH (1982) Nesting of the leatherback turtle Dermochelys coriacea in Pacific Mexico with a new estimate of the world population status. Copeia 1982:741-747

Putman NF, Naro-Maciel E (2013) Finding the 'lost years' in green turtles: insights from ocean circulation models and genetic analysis. Proc R Soc B 280:20131468

Rees AF, Saad A, Jony M (2008) Discovery of a regionally important green turtle Chelonia mydas rookery in Syria. Oryx 42:456-459

Rees A, Saad A, Jony M (2010) Syria. In: Casale P, Margaritoulis D (eds) Sea turtles in the Mediterranean: distribution, threats and conservation priorities. IUCN, Gland, p 233-243

Rees AF, Margaritoulis D, Newman R, Riggall TE, Tsaros P, Zbinden JA, Godley BJ (2013) Ecology of loggerhead marine turtles Caretta caretta in a neritic foraging habitat: movements, sex ratios and growth rates. Mar Biol 160:519-529

Rees AF, Alfaro-Shigueto J, Barata PCR, Bjorndal KA and others (2016) Are we working towards global research priorities for management and conservation of sea turtles? Endang Species Res 31:337-382

Rees AF, Carreras C, Broderick AC, Margaritoulis D, Stringell TB, Godley BJ (2017) Linking loggerhead locations: using multiple methods to determine the origin of sea turtles in feeding grounds. Mar Biol 164:30

Revelles M, Cardona L, Aguilar A, San Felix M, Fernandez G (2007a) Habitat use by immature loggerhead sea turtles in the Algerian Basin (western Mediterranean): swimming behaviour, seasonality and dispersal pattern. Mar Biol 151:1501-1515

Revelles M, Carreras C, Cardona L, Marco A and others (2007b) Evidence for an asymmetrical size exchange of loggerhead sea turtles between the Mediterranean and the Atlantic through the Straits of Gibraltar. J Exp Mar Biol Ecol 349:261-271

Revelles M, Isem-Fontanet J, Cardona L, Felix MS, Carreras C, Aguilar A (2007c) Mesoscale eddies, surface circulation and the scale of habitat selection by immature loggerhead sea turtles. J Exp Mar Biol Ecol 347:41-57

Revelles M, Camiñas JA, Cardona L, Parga M and others (2008) Tagging reveals limited exchange of immature loggerhead sea turtles (Caretta caretta) between regions in the western Mediterranean. Sci Mar 72:511-518

Revuelta O, Carreras C, Domènech F, Gozalbes P, Tomás J (2015) First report of an olive ridley (Lepidochelys olivacea) in the Mediterranean Sea. Mediterr Mar Sci 16: 346-351

Roberts MA, Schwartz TS, Karl SA (2004) Global population genetic structure and male-mediated gene flow in the green sea turtle (Chelonia mydas): analysis of microsatellite loci. Genetics 166:1857-1870

Sari F, Koseler A, Kaska Y (2017) First observation of multiple paternity in loggerhead sea turtles, Caretta caretta, nesting on Dalyan Beach, Turkey. J Exp Mar Biol Ecol 488:60-71

Schofield G (2017) Open Data requirements for applied ecology and conservation: case study of a wide-ranging marine vertebrate. Ethics Sci Environ Polit 17:19-27

Schofield G, Katselidis KA, Dimopoulos P, Pantis JD, Hays GC (2006) Behaviour analysis of the loggerhead sea turtle Caretta caretta from direct in-water observation. Endang Species Res 2:71-79
Schofield G, Katselidis KA, Dimopoulos P, Pantis JD (2008) Investigating the viability of photo-identification as an objective tool to study endangered sea turtle populations. J Exp Mar Biol Ecol 360:103-108

Schofield G, Hobson VJ, Fossette S, Lilley MKS, Katselidis KA, Hays GC (2010a) Fidelity to foraging sites, consistency of migration routes and habitat modulation of home range by sea turtles. Divers Distrib 16:840-853

Schofield G, Hobson VJ, Lilley MKS, Katselidis KA, Bishop CM, Brown P, Hays GC (2010b) Inter-annual variability in the home range of breeding turtles: implications for current and future conservation managementì. Biol Conserv 143:722-730

* Schofield G, Dimadi A, Fossette S, Katselidis KA and others (2013a) Satellite tracking large numbers of individuals to infer population level dispersal and core areas for the protection of an endangered species. Divers Distrib 19: 834-844

* Schofield G, Scott R, Dimadi A, Fossette S and others (2013b) Evidence-based marine protected area planning for a highly mobile endangered marine vertebrate. Biol Conserv 161:101-109

* Schofield G, Scott R, Katselidis KA, Mazaris AD, Hays GC (2015) Quantifying wildlife-watching ecotourism intensity on an endangered marine vertebrate. Anim Conserv 18:517-528

Schofield G, Katselidis KA, Lilley MK, Reina RD, Hays GC (2017a) Detecting elusive aspects of wildlife ecology using drones: new insights on the mating dynamics and operational sex ratios of sea turtles. Funct Ecol 31: 2310-2319

* Schofield G, Papafitsoros K, Haughey R, Katselidis K (2017b) Aerial and underwater surveys reveal temporal variation in cleaning-station use by sea turtles at a temperate breeding area. Mar Ecol Prog Ser 575:153-164

* Schroth W, Streit B, Schierwater B (1996) Evolutionary handicap for turtles. Nature 384:521-522

* Scott R, Marsh R, Hays GC (2014) Ontogeny of long distance migration. Ecology 95:2840-2850

Sella I (1982) Sea turtles in the eastern Mediterranean and northern Red Sea. In: Bjorndal KA (ed) Biology and conservation of sea turtles. Smithsonian Institution Press, Washington, DC, p 417-423

Seminoff JA, Allen CD, Balazs GH Dutton PH and others (2015) Status review of the green turtle (Chelonia mydas) under the Engangered Species Act. NOAA Tech Memo, NOAANMFS- SWFSC-539

* Shamblin BM, Bolten AB, Abreu-Grobois FA, Bjorndal KA and others (2014) Geographic patterns of genetic variation in a broadly distributed marine vertebrate: new insights into loggerhead turtle stock structure from expanded mitochondrial DNA sequences. PLOS ONE 9: e85956

Snape RTE, Beton D, Broderick AC, Çiçek BA, Fuller WJ, Özden Ö, Godley BJ (2013) Strand monitoring and anthropological surveys provide insight into marine turtle bycatch in small-scale fisheries of the eastern Mediterranean. Chelonian Conserv Biol 12:44-55

* Snape RTE, Broderick AC, Çiçek BA, Fuller WJ, Glen F, Stokes K, Godley BJ (2016) Shelf life: neritic habitat use of a turtle population highly threatened by fisheries. Divers Distrib 22:797-807

Stokes KL, Fuller WJ, Glen F, Godley BJ and others (2014) Detecting green shoots of recovery: the importance of long-term individual-based monitoring of marine turtles. 
Anim Conserv 17:593-602

Stokes KL, Broderick AC, Canbolat AF, Candan O and others (2015) Migratory corridors and foraging hotspots: critical habitats identified for Mediterranean green turtles. Divers Distrib 21:665-674

Storelli MM, Zizzo N (2014) Occurrence of organochlorine contaminants (PCBs, PCDDs and PCDFs) and pathologic findings in loggerhead sea turtles, Caretta caretta, from the Adriatic Sea (Mediterranean Sea). Sci Total Environ 472:855-861

Storelli MM, Storelli A, D'Addabbo R, Marano C, Bruno R, Marcotrigiano GO (2005) Trace elements in loggerhead turtles (Caretta caretta) from the eastern Mediterranean Sea: overview and evaluation. Environ Pollut 135:163-170

Storelli MM, Barone G, Marcotrigiano GO (2007) Polychlorinated biphenyls and other chlorinated organic contaminants in the tissues of Mediterranean loggerhead turtle Caretta caretta. Sci Total Environ 373:456-463

Synolakis CE, Kalligeris N, Foteinis S, Voukouvalas E (2008) The plight of the beaches of Crete. Proc Solutions to Coastal Disasters Conf, 13-16 April 2008, Turtle Bay, Oahu, HI, p 495-506

* Tikochinski Y, Bendelac R, Barash A, Daya A, Levy Y, Friedmann A (2012) Mitochondrial DNA STR analysis as a tool for studying the green sea turtle (Chelonia mydas) populations: the Mediterranean Sea case study. Mar Genomics 6:17-24

Tiwari M, Bjorndal KA (2000) Variation in morphology and reproduction in loggerheads, Caretta caretta, nesting in the United States, Brazil, and Greece. Herpetologica 56: 343-356

Tomás J, Raga J (2008) Occurrence of Kemp's ridley sea turtle (Lepidochelys kempii) in the Mediterranean. Mar Biodivers Rec 1:e58

Tomás J, Aznar FJ, Raga JA (2001) Feeding ecology of the loggerhead turtle Caretta caretta in the western Mediterranean. J Zool (Lond) 255:525-532

Tomás J, Gozalbes P, Raga JA, Godley BJ (2008) Bycatch of loggerhead sea turtles: insights from 14 years of stranding data. Endang Species Res 5:161-169

Tonay AM, Danyer E, Dede A, Öztürk B, Öztürk AA (2016) The stomach content of a Mediterranean monk seal (Monachus monachus): finding of green turtle (Chelonia mydas) remains. Zool Middle East 62:212-216

Tucker AD, Baldwin R, Willson A, Al-Kiyumi A, Schroeder B, Possardt E, Witherington B (2013) Preliminary estimates for loggerhead clutch frequency from Masirah, Oman derived from satellite tracking. Proc 33rd Annu Symp Sea Turtle Biology and Conservation, 5-8 February 2013, Baltimore, MD. NOAA Tech Memo NMFSSEFSC-645, p 243

Türkozan O (2000) Reproductive ecology of the loggerhead turtle, Caretta caretta, on Fethiye and Kizilot beaches, Turkey. Chelonian Conserv Biol 3:686-692

Türkozan O, Durmus SH (2000) A feeding ground for juvenile green turtles, Chelonia mydas, on the western coast of Turkey. Br Herpetol Soc Bull 71:1-5

Türkozan O, Kaska Y (2010) Turkey. In: Casale P, Margaritoulis D (eds) Sea turtles in the Mediterranean: distribution, threats and conservation priorities. IUCN, Gland, p 257-293

Turkozan O, Yilmaz C (2008) Loggerhead turtles, Caretta caretta, at Dalyan Beach, Turkey: nesting activity (2004$2005)$ and 19-year abundance trend (1987-2005). Chelonian Conserv Biol 7:178-187
Türkozan O, Taskavak E, Ilgaz Ç (2003) A review of the biology of the loggerhead turtle, Caretta caretta, at five major nesting beaches on the south-western Mediterranean coast of Turkey. Herpetol J 13:27-33

Türkozan O, Özdilek ŞY, Ergene S, Uçar AH and others (2013) Strandings of loggerhead (Caretta caretta) and green (Chelonia mydas) sea turtles along the eastern Mediterranean coast of Turkey. Herpetol J 23:11-15

* Turkozan O, Yılmaz C, Uçar AH, Carreras C, Ergene S, Aymak C, Karaman S (2018) Local differentiation in the origin of stranded loggerhead turtles, Caretta caretta, within an eastern Turkey foraging area. Ocean Coast Manage 153:70-75

*Virgili M, Vasapollo C, Lucchetti A (2018) Can ultraviolet illumination reduce sea turtle bycatch in Mediterranean set net fisheries? Fish Res 199:1-7

*Wallace BP, DiMatteo AD, Hurley BJ, Finkbeiner EM and others (2010) Regional management units for marine turtles: a novel framework for prioritizing conservation and research across multiple scales. PLOS ONE 5:e15465

Wallace BP, Stacy BA, Rissing M, Cacela D and others (2017) Estimating sea turtle exposures to Deepwater Horizon oil. Endang Species Res 33:51-67

Wibbels T (2003) Critical approaches to sex determination in sea turtles. In: Lutz PL, Musick JA, Wyneken J (eds) The biology of sea turtles, Vol II. CRC Marine Biology Series, CRC Press, Boca Raton, London, New York, Washington, DC, p 103-134

Witt MJ, Åkesson S, Broderick AC, Coyne MS and others (2010a) Assessing accuracy and utility of satellite-tracking data using Argos-linked Fastloc-GPS. Anim Behav 80:571-581

Witt MJ, Hawkes LA, Godfrey MH, Godley BJ, Broderick AC (2010b) Predicting the impacts of climate change on a globally distributed species: the case of the loggerhead turtle. J Exp Biol 213:901-911

*Wright LI, Fuller WJ, Godley BJ, McGowan A, Tregenza TOM, Broderick AC (2012a) Reconstruction of paternal genotypes over multiple breeding seasons reveals male green turtles do not breed annually. Mol Ecol 21: 3625-3635

Wright LI, Stokes KL, Fuller WJ Godley BJ and others (2012b) Turtle mating patterns buffer against disruptive effects of climate change. Proc R S B 279:2122-2127

*Yilmaz C, Turkozan O, Bardakci F (2011) Genetic structure of loggerhead turtle (Caretta caretta) populations in Turkey. Biochem Syst Ecol 39:266-276

* Zbinden JA, Davy C, Margaritoulis D, Arlettaz R (2007a) Large spatial variation and female bias in the estimated sex ratio of loggerhead sea turtle hatchlings of a Mediterranean rookery. Endang Species Res 3:305-312

Zbinden JA, Largiader AR, Leippert F, Margaritoulis D, Arlettaz R (2007b) High frequency of multiple paternity in the largest rookery of Mediterranean loggerhead sea turtles. Mol Ecol 16:3703-3711

Z Zbinden JA, Aebischer A, Margaritoulis D, Arlettaz R (2008) Important areas at sea for adult loggerhead sea turtles in the Mediterranean Sea: satellite tracking corroborates findings from potentially biased sources. Mar Biol 153: 899-906

* Zbinden JA, Bearhop S, Bradshaw P, Gill B, Margaritoulis D, Newton J, Godley BJ (2011) Migratory dichotomy and associated phenotypic variation in marine turtles revealed by satellite tracking and stable isotope analysis. Mar Ecol Prog Ser 421:291-302

Submitted: September 11, 2017; Accepted: May 4, 2018

Proofs received from author(s): July 18, 2018 